\title{
Mediating $\mathrm{K}^{+} / \mathrm{H}^{+}$Transport on Organelle Membranes to Selectively Eradicate Cancer Stem Cells by a Small Molecule
}

Fang-Fang Shen, Sheng-Yao Dai, Nai-Kei Wong, Shan Deng, Alice Sze-Tsai Wong and Dan Yang*

Morningside Laboratory for Chemical Biology, Department of Chemistry, The University of Hong Kong, Pokfulam Road, Hong Kong, China; School of Biological Sciences, The University of Hong Kong, Pokfulam Road, Hong Kong, China.

* Email: yangdan@hku.hk

\section{Contents}

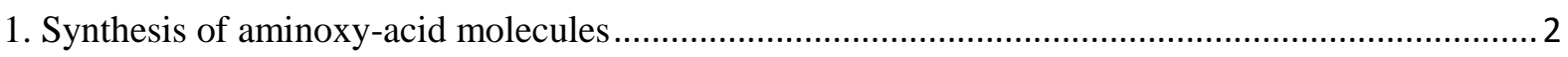

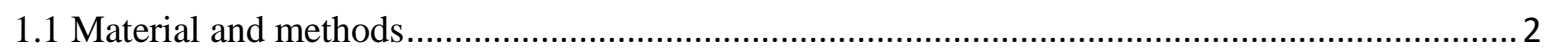

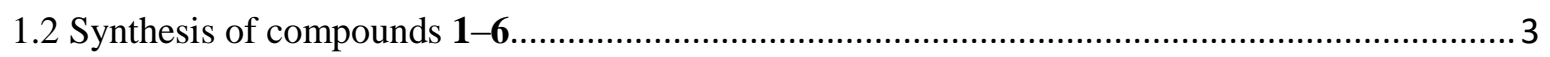

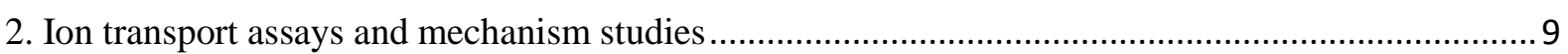

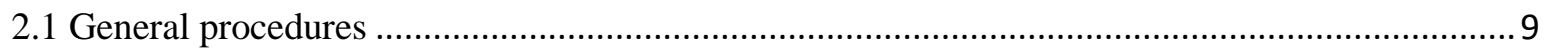

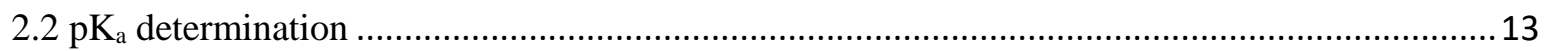

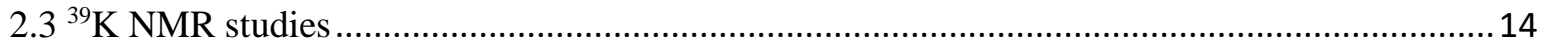

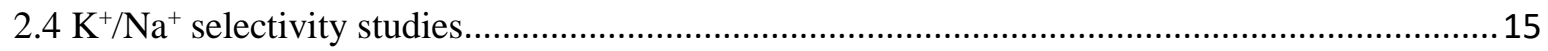

2.5 Selectivity study towards some other alkali metal cations....................................................... 19

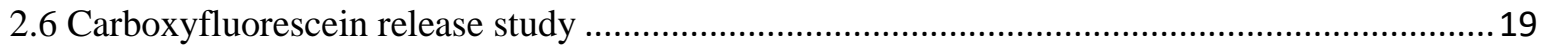

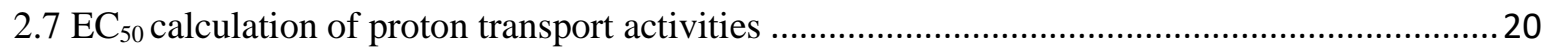

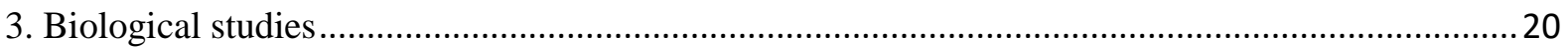

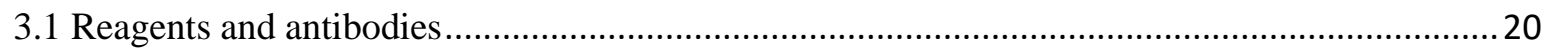

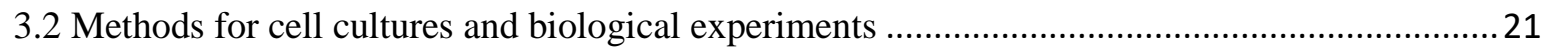

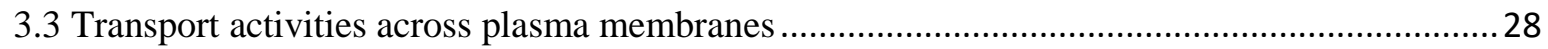

3.4 Transport activities across the mitochondria inner membranes................................................29

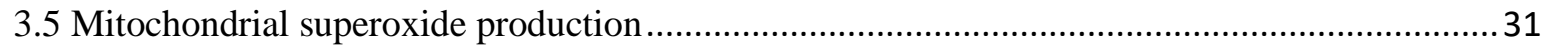

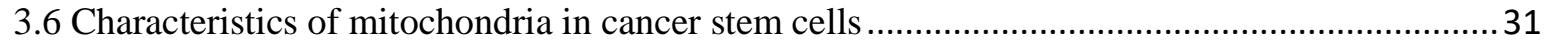

3.7 Effects on the mitochondrial membrane potential of CSCs and adherent cancer cells................32

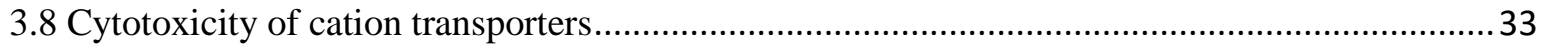

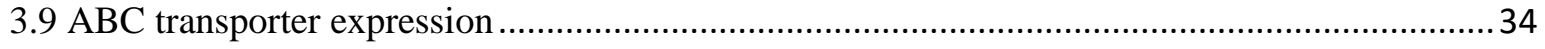

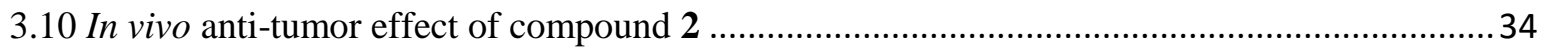

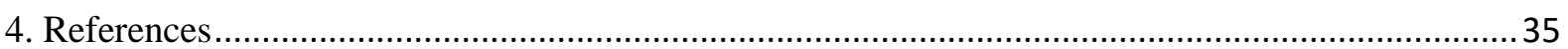

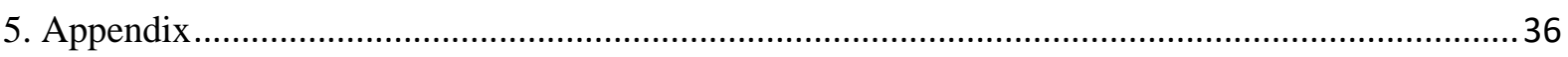




\section{Synthesis of aminoxy-acid molecules}

\subsection{Material and methods}

All reagents and solvents were purchased from Sigma Aldrich, TCI or Acros and used without further purification. All reactions requiring anhydrous conditions were carried out under argon atmosphere using oven-dried glassware. AR-grade solvents were used for all reactions. Air and moisture sensitive compounds were introduced via syringes through rubber septa under argon atmosphere. Reaction progress was monitored by TLC on pre-coated silica plates (Merck 60 F254 nm, $0.25 \mu \mathrm{m}$ ) and spots were visualized by UV and/or staining in phosphomolybdic acid (PMA) or $\mathrm{KMnO}_{4}$ solution followed by heating. Flash column chromatography was performed using Merck silica gel (230-400 mesh ASTM).

NMR spectra were acquired on Bruker Avance DPX 300 Fourier Transform Spectrometer operating at $300 \mathrm{MHz}$ for ${ }^{1} \mathrm{H}$ and at $75 \mathrm{MHz}$ for ${ }^{13} \mathrm{C}$, Bruker Avance DPX 400 Fourier Transform Spectrometer operating at $400 \mathrm{MHz}$ for ${ }^{1} \mathrm{H}, 100 \mathrm{MHz}$ for ${ }^{13} \mathrm{C}, 376 \mathrm{MHz}$ for ${ }^{19} \mathrm{~F}$ and Bruker Avance III HD 500 Spectrometer operating at $500 \mathrm{MHz}$ for ${ }^{1} \mathrm{H}, 125 \mathrm{MHz}$ for ${ }^{13} \mathrm{C}, 470$ $\mathrm{MHz}$ for ${ }^{19} \mathrm{~F}$. Chemical shifts were reported in parts per million (ppm) referenced with respect to appropriate internal standards or residual solvent peaks $\left(\mathrm{CDCl}_{3}=7.26 \mathrm{ppm}, \mathrm{DMSO}-d_{6}=\right.$ $2.50 \mathrm{ppm}, \mathrm{CD}_{3} \mathrm{OD}=3.31 \mathrm{ppm}$ and $\mathrm{CD}_{3} \mathrm{CN}=1.94 \mathrm{ppm}$ for ${ }^{1} \mathrm{H} ; \mathrm{CDCl}_{3}=77.16 \mathrm{ppm}$, DMSO$d_{6}=39.52 \mathrm{ppm}, \mathrm{CD}_{3} \mathrm{OD}=49.00 \mathrm{ppm}$ and $\mathrm{CD}_{3} \mathrm{CN}=1.32,118.26 \mathrm{ppm}$ for $\left.{ }^{13} \mathrm{C}\right)$. The following abbreviations were used in reporting spectra, br s (broad singlet), s (singlet), d (doublet), $\mathrm{t}$ (triplet), q (quartet), $m$ (multiplet), dd (doublet of doublets) and $\mathrm{AB}_{\mathrm{q}}$ ( $\mathrm{AB}$ quartet). Highresolution mass spectra were obtained on Bruker maXis II High-Resolution QTOF using ESI mode. Fluorescence measurements were carried out on a Hitachi F-2500 fluorescence spectrometer with a slit width of $2.5 \mathrm{~nm}$ and photomultiplier at $400 \mathrm{~V}$ or $700 \mathrm{~V}$. X-ray crystallographic spectra were collected with APEX3 v2015.5-2 (Bruker-AXS, 2015). Circular dichroism (CD) spectra were recorded on a Jasco-815 spectropolarimeter at 180-300 nm wavelengths at room temperature. The path lengths of CD cells were $1 \mathrm{~mm}$ or $0.1 \mathrm{~mm}$. Data were converted to molar ellipticity according to the equation: $[\theta]=\Psi \mathrm{M} /(1001 \mathrm{c})$, where $\Psi$ is the ellipticity in degrees; $M$ is the molecular weight of test compound; 1 is the length of the $C D$ cell in $\mathrm{dm}$, and $\mathrm{c}$ is the concentration of test compound in $\mathrm{g} / \mathrm{mL}$. 


\subsection{Synthesis of compounds 1-6}
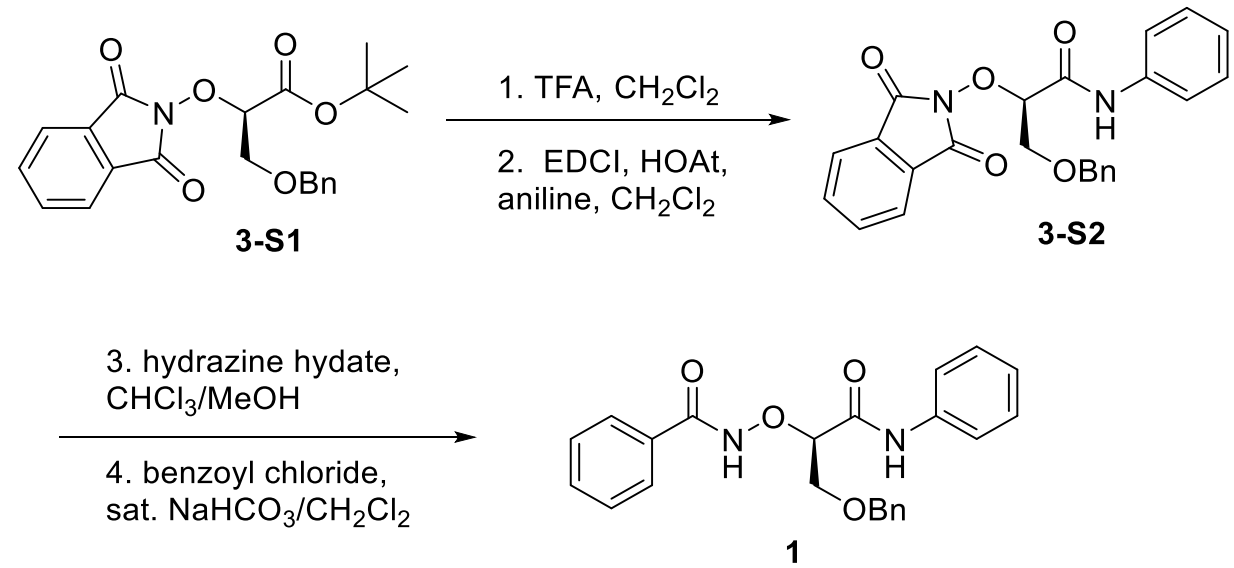

Scheme S1. Synthesis of compound 1.

Compound 3-S1 was synthesized according to the literature reported procedures ${ }^{1}$. To a solution of compound 3-S1 (198.7 mg, $0.50 \mathrm{mmol})$ in $\mathrm{CH}_{2} \mathrm{Cl}_{2}(2.5 \mathrm{~mL})$ was added an equal volume of $\mathrm{CF}_{3} \mathrm{COOH}(2.5 \mathrm{~mL})$ through a syringe at room temperature. After being stirred at room temperature for $3 \mathrm{~h}$, the reaction mixture was concentrated in vacuo. The residue was azeotroped with toluene twice to give a free acid, which was used directly in the following steps without further purification. To a solution of the free acid in $\mathrm{CH}_{2} \mathrm{Cl}_{2}(2.5 \mathrm{~mL})$ were sequentially added EDCI (143.8 mg, $0.75 \mathrm{mmol})$, HOAt $(88.5 \mathrm{mg}, 0.65 \mathrm{mmol})$ and aniline $(51.2 \mathrm{mg}, 0.60 \mathrm{mmol})$. The reaction mixture was stirred overnight at room temperature, then diluted with $\mathrm{CH}_{2} \mathrm{Cl}_{2}$, washed with $5 \% \mathrm{NaHCO}_{3}, 0.5 \mathrm{~N} \mathrm{HCl}$ and brine, and dried over anhydrous $\mathrm{Na}_{2} \mathrm{SO}_{4}$. The organic layer was concentrated in vacuo. The residue was purified by silica gel column chromatography to afford compound 3-S2 (156.2 $\mathrm{mg}, 75 \%)$ as a white solid. Compound 3-S2 was characterized by the following data: ${ }^{1} \mathrm{H} \mathrm{NMR}\left(400 \mathrm{MHz}, \mathrm{CDCl}_{3}\right) \delta 9.65$ (s, 1H), 7.80-7.69 (m, 6H), 7.36-7.21 (m, 7H), $7.12(\mathrm{t}, J=7.4 \mathrm{~Hz}, 1 \mathrm{H}), 4.92-4.91(\mathrm{~m}, 1 \mathrm{H})$, $4.63\left(\mathrm{AB}_{\mathrm{q}}, J_{\mathrm{AB}}=12.0 \mathrm{~Hz}, 2 \mathrm{H}\right), 4.24-4.21(\mathrm{~m}, 1 \mathrm{H}), 4.16-4.12(\mathrm{dd}, J=12.0,3.0 \mathrm{~Hz}, 1 \mathrm{H}) ;{ }^{13} \mathrm{C}$ $\operatorname{NMR}\left(100 \mathrm{MHz}, \mathrm{CDCl}_{3}\right) \delta 165.5,163.9,137.5,137.5,135.1,134.2,129.0,128.5,128.4,127.7$, 124.7, 124.1, 120.0, 87.8, 73.7, 69.7; HRMS (ESI) for $\mathrm{C}_{24} \mathrm{H}_{21} \mathrm{~N}_{2} \mathrm{O}_{5}\left(\mathrm{M}+\mathrm{H}^{+}\right)$: calcd 417.1445, found 417.1441.

To a solution of compound 3-S2 $(124.9 \mathrm{mg}, 0.30 \mathrm{mmol})$ in $\mathrm{MeOH} / \mathrm{CHCl}_{3}(1: 1,2.5 \mathrm{~mL})$ was added $\mathrm{NH}_{2} \mathrm{NH}_{2} \cdot \mathrm{H}_{2} \mathrm{O}(25.0 \mathrm{mg}, 0.50 \mathrm{mmol})$. After being stirred at room temperature for $2.5 \mathrm{~h}$, the reaction mixture was concentrated in vacuo. The residue was dissolved in $\mathrm{CH}_{2} \mathrm{Cl}_{2}$ and washed with $5 \% \mathrm{NaHCO}_{3}$ and brine. The organic layer was dried over anhydrous $\mathrm{Na}_{2} \mathrm{SO}_{4}$ and 
was concentrated in vacuo to give a crude product of the free amine, which was used directly in the following steps without further purification. To a solution of the free amine in $\mathrm{MeOH}$ $(1.0 \mathrm{~mL})$ was added saturated $\mathrm{NaHCO}_{3}$ solution $(1.0 \mathrm{~mL})$. Then, benzoyl chloride $(56.2 \mathrm{mg}$, $0.40 \mathrm{mmol}$ ) was added dropwise. After being stirred overnight, the reaction mixture was diluted with $\mathrm{CH}_{2} \mathrm{Cl}_{2}$. The aqueous layer was extracted with $\mathrm{CH}_{2} \mathrm{Cl}_{2}$ for three times. The combined organic layer was dried over anhydrous $\mathrm{Na}_{2} \mathrm{SO}_{4}$ and was concentrated in vacuo. The crude oil was purified by flash column chromatography to afford compound 1 (296.7 $\mathrm{mg}, 76 \%)$ as a white solid: ${ }^{1} \mathrm{H}$ NMR $\left(400 \mathrm{MHz}, \mathrm{CDCl}_{3}\right) \delta 10.62(\mathrm{~s}, 1 \mathrm{H}), 9.75(\mathrm{~s}, 1 \mathrm{H}), 7.67(\mathrm{~d}, J=7.7 \mathrm{~Hz}, 2 \mathrm{H})$, $7.62(\mathrm{~d}, \mathrm{~J}=7.3 \mathrm{~Hz}, 2 \mathrm{H}), 7.48-7.44(\mathrm{~m}, 1 \mathrm{H}), 7.35-7.32(\mathrm{~m}, 2 \mathrm{H}), 7.28-7.22(\mathrm{~m}, 7 \mathrm{H}), 7.06-7.02$ $(\mathrm{m}, 1 \mathrm{H}), 4.60(\mathrm{dd}, J=8.7,2.7 \mathrm{~Hz}, 1 \mathrm{H}), 4.56,4.52\left(\mathrm{ABq}, J_{\mathrm{AB}}=12.0 \mathrm{~Hz}, 2 \mathrm{H}\right), 4.15(\mathrm{dd}, J=11.2$, $2.8 \mathrm{~Hz}, 1 \mathrm{H}), 3.89(\mathrm{dd}, J=11.1,8.8 \mathrm{~Hz}, 1 \mathrm{H}) ;{ }^{13} \mathrm{C} \mathrm{NMR}\left(100 \mathrm{MHz}, \mathrm{CDCl}_{3}\right) \delta 168.1,166.2$, 137.8, 137.3, 132.8, 130.4, 128.9, 128.8, 128.6, 128.2, 128.1, 127.2, 124.4, 119.9, 87.0, 73.8, 70.1; HRMS (ESI) for $\mathrm{C}_{23} \mathrm{H}_{22} \mathrm{~N}_{2} \mathrm{O}_{4} \mathrm{Na}\left(\mathrm{M}+\mathrm{Na}^{+}\right)$: calcd 413.1477, found 413.1456.
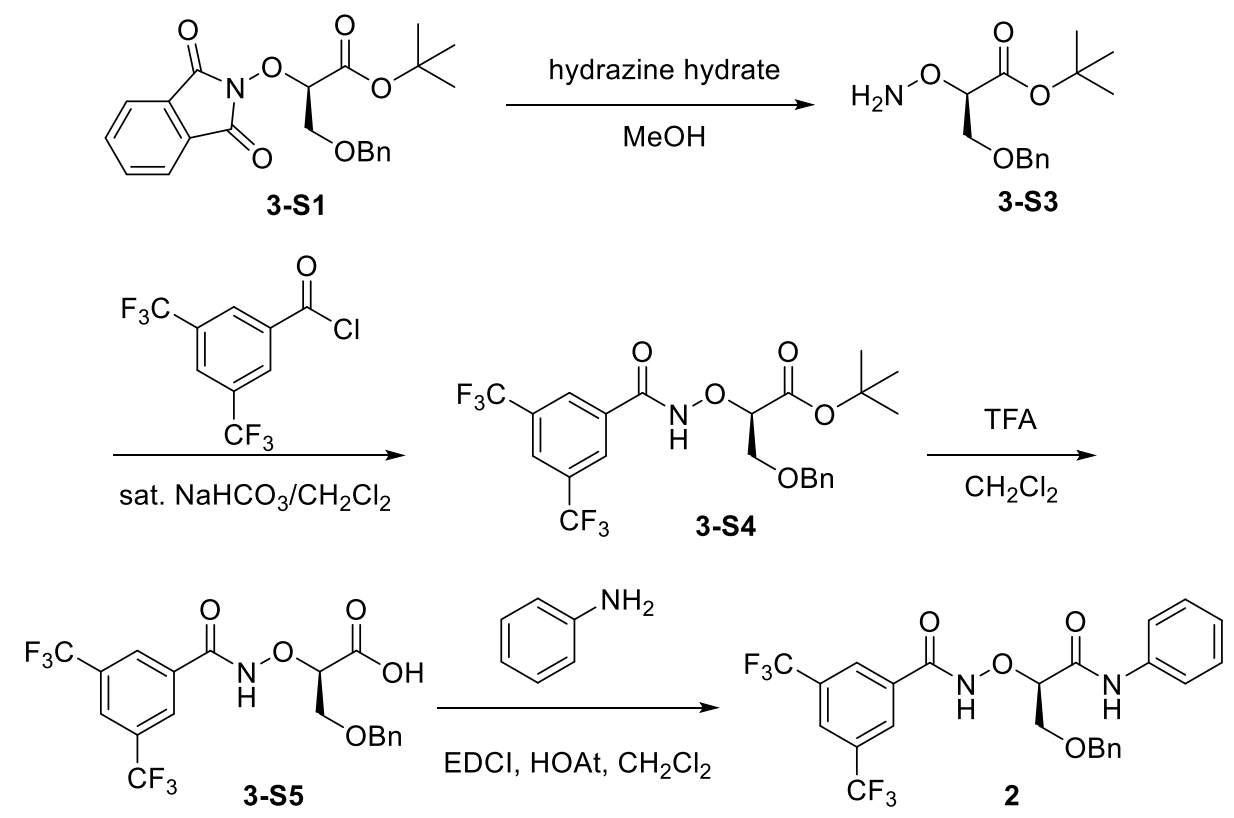

Scheme S2. Synthesis of compound 2.

To a solution of compound 3-S1 (794.9 mg, $2.0 \mathrm{mmol})$ in $\mathrm{MeOH}(20 \mathrm{~mL})$ was added $\mathrm{NH}_{2} \mathrm{NH}_{2} \cdot \mathrm{H}_{2} \mathrm{O}$ (400.4 mg, $8.0 \mathrm{mmol}$ ). After being stirred at room temperature for $2.5 \mathrm{~h}$, the reaction mixture was concentrated in vacuo. The residue was dissolved in $\mathrm{CH}_{2} \mathrm{Cl}_{2}$ and washed with $5 \% \mathrm{NaHCO}_{3}$ and brine. The organic layer was dried over anhydrous $\mathrm{Na}_{2} \mathrm{SO}_{4}$ and was concentrated in vacuo to give a crude product of compound $\mathbf{3 - S 3}$, which was used directly in the following steps without further purification. 
To a solution of compound 3-S3 dissolved in $\mathrm{CH}_{2} \mathrm{Cl}_{2}(10 \mathrm{~mL})$ was added saturated aqueous $\mathrm{NaHCO}_{3}$ solution $(10 \mathrm{~mL})$. Then, 3,5-bis(trifluoromethyl)benzoyl chloride $(553.1 \mathrm{mg}, 2.0$ mmol) was added dropwise in an ice bath. After being stirred at $0^{\circ} \mathrm{C}$ for $1 \mathrm{~h}$, the reaction mixture was diluted with $\mathrm{CH}_{2} \mathrm{Cl}_{2}$. The aqueous layer was extracted with $\mathrm{CH}_{2} \mathrm{Cl}_{2}$ for three times. The combined organic layer was dried over anhydrous $\mathrm{Na}_{2} \mathrm{SO}_{4}$ and was concentrated in vacuo. The crude oil was purified by flash column chromatography to afford compound 3-S4 (862.6 mg, $85 \%$ ) as colorless oil. ${ }^{1} \mathrm{H} \mathrm{NMR}\left(500 \mathrm{MHz}, \mathrm{CD}_{3} \mathrm{CN}\right) \delta 10.17$ (br s, $\left.1 \mathrm{H}\right), 8.24(\mathrm{~s}, 2 \mathrm{H}), 8.16$ (s, $1 \mathrm{H}), 7.36-7.29(\mathrm{~m}, 5 \mathrm{H}), 4.63(\mathrm{t}, J=3.3 \mathrm{~Hz}, 1 \mathrm{H}), 4.54\left(\mathrm{AB}_{\mathrm{q}}, J_{\mathrm{AB}}=11.6 \mathrm{~Hz}, 2 \mathrm{H}\right), 3.93-3.87(\mathrm{~m}$, 2H), $1.46(\mathrm{~s}, 9 \mathrm{H}) ;{ }^{13} \mathrm{C} \mathrm{NMR}\left(125 \mathrm{MHz}, \mathrm{CDCl}_{3}\right) \delta 169.0,163.4,137.4,133.8,132.2\left(\mathrm{q},{ }^{2} J_{\mathrm{C}, \mathrm{F}}=\right.$ $34.0 \mathrm{~Hz}$ ), 128.5, 128.0, 127.9, 127.6, 125.3, 123.0 (q, $\left.{ }^{1} J_{\mathrm{C}, \mathrm{F}}=271.3 \mathrm{~Hz}\right), 83.4,77.4,73.7,69.2$, $28.1 ;{ }^{19} \mathrm{~F}\left(376 \mathrm{MHz}, \mathrm{CDCl}_{3}\right) \delta-63.0$; HRMS (ESI) for $\mathrm{C}_{23} \mathrm{H}_{23} \mathrm{~F}_{6} \mathrm{NO}_{5} \mathrm{Na}\left(\mathrm{M}+\mathrm{Na}^{+}\right)$: calcd 530.1378 , found 530.1395 .

To a solution of compound 3-S4 $(152.2 \mathrm{mg}, 0.30 \mathrm{mmol})$ in $\mathrm{CH}_{2} \mathrm{Cl}_{2}(1.5 \mathrm{~mL})$ was added an equal volume of $\mathrm{CF}_{3} \mathrm{COOH}(1.5 \mathrm{~mL})$ at room temperature. After being stirred at room temperature for $3 \mathrm{~h}$, the reaction mixture was concentrated in vacuo. The residue was azeotroped with toluene twice to give compound 3-S5 as a white solid, which was used directly in the following step without further purification.

To a solution of compound 3-S5 $(22.6 \mathrm{mg}, 0.05 \mathrm{mmol})$ in $\mathrm{CH}_{2} \mathrm{Cl}_{2}(1 \mathrm{~mL})$ were added sequentially EDCI (15.3 mg, $0.08 \mathrm{mmol}), \operatorname{HOAt}(9.5 \mathrm{mg}, 0.07 \mathrm{mmol})$ and aniline (5.6 mg, 0.06 $\mathrm{mmol})$. The reaction mixture was stirred overnight at room temperature, then was diluted with $\mathrm{CH}_{2} \mathrm{Cl}_{2}$, washed with $5 \% \mathrm{NaHCO}_{3}, 0.5 \mathrm{~N} \mathrm{HCl}$, brine and dried over anhydrous $\mathrm{Na}_{2} \mathrm{SO}_{4}$. The organic layer was concentrated in vacuo. The residue was purified by silica gel column chromatography to afford compound $2(21.6 \mathrm{mg}, 82 \%)$ as a white solid. ${ }^{1} \mathrm{H}$ NMR $(400 \mathrm{MHz}$, $\left.\mathrm{CDCl}_{3}\right) \delta 10.34($ br s, 2H), $8.17(\mathrm{~s}, 2 \mathrm{H}), 8.02(\mathrm{~s}, 1 \mathrm{H}), 7.66(\mathrm{~s}, 1 \mathrm{H}), 7.65(\mathrm{~s}, 1 \mathrm{H}) 7.34-7.25(\mathrm{~m}$, $7 \mathrm{H}), 7.12(\mathrm{tt}, J=7.4,1.0 \mathrm{~Hz}, 1 \mathrm{H}), 4.70-4.68(\mathrm{~m}, 1 \mathrm{H}), 4.62,4.57\left(\mathrm{AB}_{\mathrm{q}}, J_{\mathrm{AB}}=11.8 \mathrm{~Hz}, 2 \mathrm{H}\right)$, $4.13(\mathrm{dd}, J=11.6,2.5 \mathrm{~Hz}, 1 \mathrm{H}), 3.95(\mathrm{dd}, J=11.1,8.2 \mathrm{~Hz}, 1 \mathrm{H}) ;{ }^{13} \mathrm{C}\left(125 \mathrm{MHz}, \mathrm{CDCl}_{3}\right) \delta 166.3$, $164.9,137.4,137.2,132.8,132.6\left(\mathrm{q},{ }^{2} J_{\mathrm{C}, \mathrm{F}}=33.2 \mathrm{~Hz}\right), 129.1,128.8,128.4,128.0,127.8,126.2$, 125.0, $122.9\left(\mathrm{q},{ }^{1} J_{\mathrm{C}, \mathrm{F}}=273.1 \mathrm{~Hz}\right), 120.2,87.2,74.1,70.1 ;{ }^{19} \mathrm{~F}\left(376 \mathrm{MHz}, \mathrm{CDCl}_{3}\right) \delta-62.9$; HRMS (ESI) for $\mathrm{C}_{25} \mathrm{H}_{21} \mathrm{~F}_{6} \mathrm{~N}_{2} \mathrm{O}_{4}\left(\mathrm{M}+\mathrm{H}^{+}\right)$: calcd 527.1400, found 527.1413. 
<smiles>CN(OC(COCc1ccccc1)C(=O)ONC(=O)c1cc(C(F)(F)F)cc(C(F)(F)F)c1)C(=O)N(OC(COCc1ccccc1)C(=O)OC(C)(C)C)C(=O)c1cc(C(F)(F)F)cc(C(F)(F)F)c1</smiles><smiles>CC(C)O[C@H](Cc1ccccc1)C(=O)Nc1ccccc1</smiles>

Scheme S3. Synthesis of compound 3.

To a solution of compound 3-S4 $(50.7 \mathrm{mg}, 0.10 \mathrm{mmol})$ in DMF $(1 \mathrm{~mL})$ was added $60 \% \mathrm{NaH}$ $(5.2 \mathrm{mg}, 0.13 \mathrm{mmol})$ at $0^{\circ} \mathrm{C}$. After being stirred for $0.5 \mathrm{~h}, \mathrm{CH}_{3} \mathrm{I}(18.5 \mathrm{mg}, 0.13 \mathrm{mmol})$ was added dropwise. The reaction mixture was stirred for another $2 \mathrm{~h}$ at room temperature, then concentrated in vacuo. The residue was purified by silica gel column chromatography to afford compound 3-S6 (37.1 mg, 52\% yield) as an oil. ${ }^{1} \mathrm{H}$ NMR (500 MHz, $\left.\mathrm{CDCl}_{3}\right) \delta 8.17(\mathrm{~s}, 2 \mathrm{H})$, $7.87(\mathrm{~s}, 1 \mathrm{H}), 7.34-7.28(\mathrm{~m}, 5 \mathrm{H}), 4.75(\mathrm{dd}, J=5.7,3.3 \mathrm{~Hz}, 1 \mathrm{H}), 4.66,4.59\left(\mathrm{AB}_{\mathrm{q}}, J_{A B}=15.0 \mathrm{~Hz}\right.$, 2H), $4.31(\mathrm{~s}, 3 \mathrm{H}), 3.94-3.88(\mathrm{~m}, 2 \mathrm{H}), 1.48(\mathrm{~s}, 9 \mathrm{H}),{ }^{13} \mathrm{C} \mathrm{NMR}\left(125 \mathrm{MHz}, \mathrm{CDCl}_{3}\right) \delta 169.8,153.2$, $139.1,135.3,133.0\left(\mathrm{q},{ }^{2} J_{\mathrm{C}, \mathrm{F}}=33.4 \mathrm{~Hz}\right), 129.7,129.1,129.0 .128 .1,124.7,124.3\left(\mathrm{q},{ }^{1} J_{\mathrm{C}, \mathrm{F}}=\right.$ $273.2 \mathrm{~Hz}), 84.1,83.5,74.8,70.4,62.6,29.4 ;{ }^{19} \mathrm{~F}\left(376 \mathrm{MHz}, \mathrm{CD}_{3} \mathrm{CN}\right) \delta-63.0$. HRMS (ESI) for $\mathrm{C}_{20} \mathrm{H}_{17} \mathrm{~F}_{6} \mathrm{NO}_{5}\left(\mathrm{M}-t-\mathrm{Bu}+\mathrm{H}^{+}\right)$: calcd 466.1089, found 466.1079.

To a solution of compound 3-S6 $(35.7 \mathrm{mg}, 0.05 \mathrm{mmol})$ in $\mathrm{CH}_{2} \mathrm{Cl}_{2}(0.5 \mathrm{~mL})$ was added an equal volume of $\mathrm{CF}_{3} \mathrm{COOH}(0.5 \mathrm{~mL})$ through a syringe at room temperature. After being stirred at room temperature for $3 \mathrm{~h}$, the reaction mixture was concentrated in vacuo. The residue was azeotroped with toluene twice to give free acid compound 3-S7 as a white solid, which was used directly in the next step.

To a solution of compound 3-S7 in $\mathrm{CH}_{2} \mathrm{Cl}_{2}(1 \mathrm{~mL})$ were added EDCI (15.3 mg, $\left.0.08 \mathrm{mmol}\right)$, HOAt $(9.5 \mathrm{mg}, 0.07 \mathrm{mmol})$ and aniline $(5.6 \mathrm{mg}, 0.06 \mathrm{mmol})$, sequentially. The reaction was stirred overnight at room temperature, then diluted with $\mathrm{CH}_{2} \mathrm{Cl}_{2}$, washed with $5 \% \mathrm{NaHCO}_{3}$, $0.5 \mathrm{~N} \mathrm{HCl}$ and brine and dried over anhydrous $\mathrm{Na}_{2} \mathrm{SO}_{4}$. The organic layer was concentrated in vacuo. The residue was purified by silica gel column chromatography to afford compound 3 (22.2 mg, 82\% yield) as an oil. ${ }^{1} \mathrm{H}$ NMR (400 MHz, $\left.\mathrm{CDCl}_{3}\right) \delta 10.37(\mathrm{~s}, 1 \mathrm{H}), 8.02-8.00(\mathrm{~m}$, 3H), $7.68(\mathrm{~s}, 1 \mathrm{H}), 7.65(\mathrm{~s}, 1 \mathrm{H}), 7.38-7.28(\mathrm{~m}, 7 \mathrm{H}), 7.13-7.08(\mathrm{~m}, 1 \mathrm{H}), 4.69$ (dd, $J=8.3,2.2$ 
$\mathrm{Hz}, 1 \mathrm{H}), 4.63(\mathrm{~s}, 2 \mathrm{H}), 4.18-4.15(\mathrm{~m}, 1 \mathrm{H}), 3.85(\mathrm{dd}, J=11.2,8.3 \mathrm{~Hz}, 1 \mathrm{H}), 3.42(\mathrm{~s}, 3 \mathrm{H}) ;{ }^{13} \mathrm{C}$ $\operatorname{NMR}\left(150 \mathrm{MHz}, \mathrm{CDCl}_{3}\right) \delta 169.2,165.6,137.6,137.3,135.5,132.4\left(\mathrm{q},{ }^{2} J_{\mathrm{C}, \mathrm{F}}=34.1 \mathrm{~Hz}\right), 129.0$, 128.6, 128.3, 128.0, 127.8, 125.4, 124.5, 122.7 (q, ${ }^{1} J_{\mathrm{C}, \mathrm{F}}=277.1 \mathrm{~Hz}$ ), 119.7, 86.8, 73.8, 69.9, $40.2 ;{ }^{19} \mathrm{~F}\left(376 \mathrm{MHz}, \mathrm{CD}_{3} \mathrm{CN}\right) \delta-62.9$. HRMS (ESI) for $\mathrm{C}_{26} \mathrm{H}_{23} \mathrm{~F}_{6} \mathrm{~N}_{2} \mathrm{O}_{4}\left(\mathrm{M}+\mathrm{H}^{+}\right)$: calcd 541.1557, found 541.1556 .

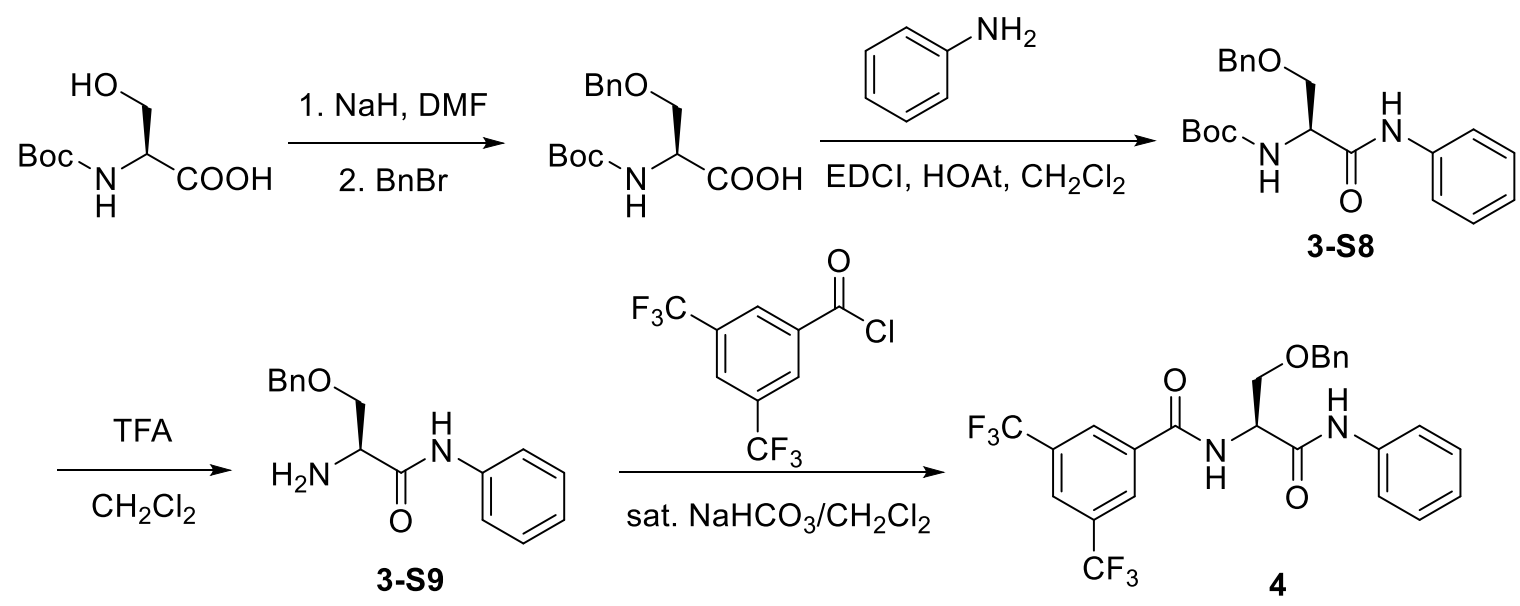

Scheme S4. Synthesis of compound 4.

To a solution of $N$-(tert-butoxycarbonyl)-L-serine $(205.1 \mathrm{mg}, 1.0 \mathrm{mmol})$ in anhydrous DMF $(10 \mathrm{~mL})$ was added $60 \% \mathrm{NaH}(96.0 \mathrm{mg}, 2.40 \mathrm{mmol})$ in an ice bath. After being stirred for $1 \mathrm{~h}$, benzyl bromide $(188.1 \mathrm{mg}, 1.10 \mathrm{mmol})$ was added. The reaction mixture was stirred at room temperature for $2 \mathrm{~h}$, then diluted with water and extracted with diethyl ether twice. The aqueous layer was adjusted to $\mathrm{pH}$ below 3.5 and extracted with ethyl acetate 3 times. The combined organic layer was dried over $\mathrm{Na}_{2} \mathrm{SO}_{4}$ and was concentrated in vacuo to give the free acid, Boc$O$-benzyl-L-serine, as oil, which was used directly in the next step.

To a solution of Boc-O-benzyl-L-serine obtained from the last step in $\mathrm{CH}_{2} \mathrm{Cl}_{2}(10 \mathrm{~mL})$ were added EDCI (287.6 mg, $1.50 \mathrm{mmol})$, HOAt (176.9 mg, $1.30 \mathrm{mmol})$ and aniline (102.4 mg, 1.10 mmol) subsequently. The reaction mixture was stirred overnight at room temperature, then diluted with $\mathrm{CH}_{2} \mathrm{Cl}_{2}$, washed with $5 \% \mathrm{NaHCO}_{3}, 0.5 \mathrm{~N} \mathrm{HCl}$ and brine. The organic layer was dried over anhydrous $\mathrm{Na}_{2} \mathrm{SO}_{4}$ and was concentrated in vacuo. The residue was purified by silica gel column chromatography to afford compound 3-S8 (262.8 mg, 71\%) as an oil. ${ }^{1} \mathrm{H}$ NMR $\left(500 \mathrm{MHz}, \mathrm{CDCl}_{3}\right) \delta 8.43(\mathrm{~s}, 1 \mathrm{H}), 7.46(\mathrm{~d}, J=7.9,2 \mathrm{H}), 7.35-7.25(\mathrm{~m}, 7 \mathrm{H}), 7.09$ (t, $J=7.4 \mathrm{~Hz}$, $1 \mathrm{H}), 5.56(\mathrm{br}, 1 \mathrm{H}), 4.62,4.54\left(\mathrm{AB}_{\mathrm{q}}, J_{\mathrm{AB}}=10.0 \mathrm{~Hz}, 2 \mathrm{H}\right), 4.43(\mathrm{br}, 1 \mathrm{H}), 3.98$ (dd, $J=9.1,3.7 \mathrm{~Hz}$, $1 \mathrm{H}), 3.65(\mathrm{dd}, J=9.5,7.0 \mathrm{~Hz}, 1 \mathrm{H}), 1.47(\mathrm{~s}, 9 \mathrm{H}) ;{ }^{13} \mathrm{C} \mathrm{NMR}\left(125 \mathrm{MHz}, \mathrm{CDCl}_{3}\right) \delta 168.6,155.8$, 
$137.6,137.4,129.1,128.7,128.2,128.0,124.5,120.0,80.6,73.7,69.9,54.4,28.4$;

To a solution of compound 3-S8 $(262.8 \mathrm{mg}, 0.71 \mathrm{mmol})$ in $\mathrm{CH}_{2} \mathrm{Cl}_{2}(7 \mathrm{~mL})$ was added an equal volume of $\mathrm{CF}_{3} \mathrm{COOH}(7.0 \mathrm{~mL})$ through a syringe at room temperature. After being stirred at room temperature for $3 \mathrm{~h}$, the reaction mixture was concentrated in vacuo. The residue was azeotroped with toluene twice to give free amine 3-S9 as a white solid, which was used directly in the next step without further purification.

To a solution of compound 3-S9 in $\mathrm{CH}_{2} \mathrm{Cl}_{2}(10 \mathrm{~mL})$ was added saturated $\mathrm{NaHCO}_{3}$ solution (10 $\mathrm{mL})$. Then 3,5-bis(trifluoromethyl)benzoyl chloride $(221.2 \mathrm{mg}, 0.80 \mathrm{mmol})$ was added dropwise. After being stirred overnight, the reaction mixture was diluted with $\mathrm{CH}_{2} \mathrm{Cl}_{2}$. The aqueous layer was extracted with $\mathrm{CH}_{2} \mathrm{Cl}_{2}$ for three times. The combined organic layer was dried over anhydrous $\mathrm{Na}_{2} \mathrm{SO}_{4}$ and was concentrated in vacuo. The crude oil was purified by flash column chromatography to afford compound 4 (293.6 $\mathrm{mg}, 81 \%$ yield) as a white solid; ${ }^{1} \mathrm{H}$ NMR (400 MHz, $\left.\mathrm{CDCl}_{3}\right) \delta 8.63(\mathrm{~s}, 1 \mathrm{H}), 8.20(\mathrm{~s}, 2 \mathrm{H}), 7.93(\mathrm{~s}, 1 \mathrm{H}), 7.53(\mathrm{~d}, J=6.5 \mathrm{~Hz}, 1 \mathrm{H})$, $7.36-7.18(\mathrm{~m}, 8 \mathrm{H}), 7.05(\mathrm{t}, J=7.3 \mathrm{~Hz}, 1 \mathrm{H}), 4.92-4.88(\mathrm{~m}, 1 \mathrm{H}), 4.62,4.52\left(\mathrm{AB}_{\mathrm{q}}, J_{A B}=12.0\right.$ $\mathrm{Hz}, 2 \mathrm{H}), 3.99(\mathrm{dd}, J=9.5,6.1 \mathrm{~Hz}, 1 \mathrm{H}), 3.69-3.64(\mathrm{~m}, 1 \mathrm{H}) ;{ }^{13} \mathrm{C} \mathrm{NMR}\left(125 \mathrm{MHz}, \mathrm{CDCl}_{3}\right) \delta$ 167.9, 164.6, 137.3, 137.0, 135.7, 132.4 (q, $\left.{ }^{2} J_{\mathrm{C}, \mathrm{F}}=34.0 \mathrm{~Hz}\right), 129.2,128.9,128.5,128.2$, 127.7 , 125.6, 125.0, $122.8\left(\mathrm{q},{ }^{1} J_{\mathrm{C}, \mathrm{F}}=273.0 \mathrm{~Hz}\right), 120.1,74.0,69.2,53.4 ;{ }^{19} \mathrm{~F}\left(376 \mathrm{MHz}, \mathrm{CDCl}_{3}\right) \delta$ -62.9 ; HRMS (ESI) for $\mathrm{C}_{25} \mathrm{H}_{21} \mathrm{~F}_{6} \mathrm{~N}_{2} \mathrm{O}_{3}\left(\mathrm{M}+\mathrm{H}^{+}\right)$: calcd 511.1451, found 511.1465.
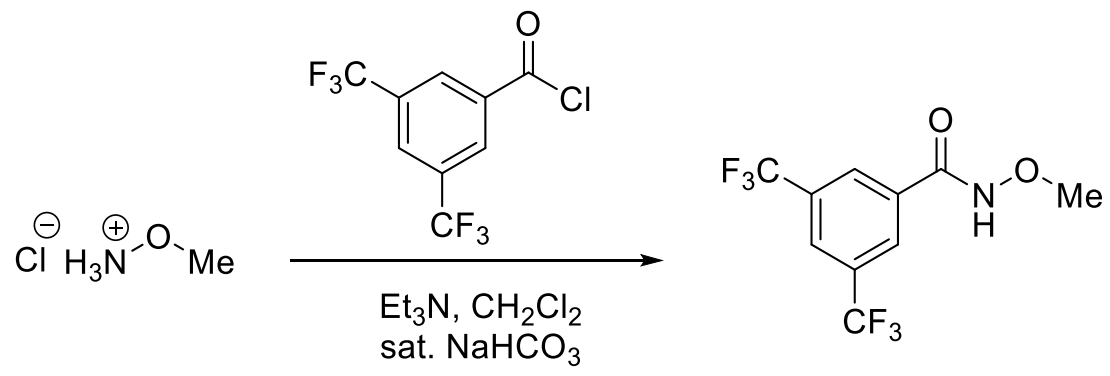

5

Scheme S5. Synthesis of compound 5.

To a solution of $O$-methylhydroxylammonium chloride $(16.7 \mathrm{mg}, 0.20 \mathrm{mmol})$ in $\mathrm{CH}_{2} \mathrm{Cl}_{2}(2 \mathrm{~mL})$ was added triethylamine $(32.4 \mathrm{mg}, 0.32 \mathrm{mmol})$ at $0^{\circ} \mathrm{C}$. The reaction was stirred for $0.5 \mathrm{~h}$, then 3,5-bis(trifluoromethyl)benzoyl chloride $(60.8 \mathrm{mg}, 0.22 \mathrm{mmol})$ was added dropwise. After being stirred overnight, the reaction mixture was diluted with $\mathrm{CH}_{2} \mathrm{Cl}_{2}$. The aqueous layer was extracted with $\mathrm{CH}_{2} \mathrm{Cl}_{2}$ for three times. The combined organic layer was dried over anhydrous $\mathrm{Na}_{2} \mathrm{SO}_{4}$ and was concentrated in vacuo. The crude oil was purified by flash column 
chromatography to afford compound 5 (48.8 mg, 85\%) as a white solid. ${ }^{1} \mathrm{H}$ NMR (400 MHz, $\left.\mathrm{CD}_{3} \mathrm{OD}\right) \delta 8.38(\mathrm{~s}, 1 \mathrm{H}), 8.20(\mathrm{~s}, 2 \mathrm{H}), 3.88(\mathrm{~s}, 3 \mathrm{H}) ;{ }^{13} \mathrm{C} \mathrm{NMR}\left(150 \mathrm{MHz}, \mathrm{CD}_{3} \mathrm{OD}\right) \delta 163.8$, $135.9,133.4,\left(\mathrm{q},{ }^{2} J_{\mathrm{C}, \mathrm{F}}=38.3 \mathrm{~Hz}\right), 128.9,126.5,124.7$ (q, $\left.{ }^{1} J_{\mathrm{C}, \mathrm{F}}=274.5 \mathrm{~Hz}\right), 64.6 ;{ }^{19} \mathrm{~F}(376 \mathrm{MHz}$, $\left.\mathrm{CD}_{3} \mathrm{CN}\right) \delta-63.0$; HRMS (ESI) for $\mathrm{C}_{10} \mathrm{H}_{7} \mathrm{~F}_{6} \mathrm{NO}_{2}\left(\mathrm{M}+\mathrm{H}^{+}\right)$: calcd 288.0454, found 288.0460.

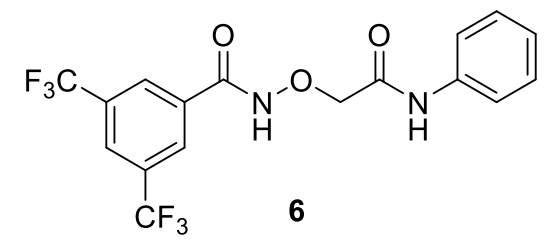

According to the same procedures of compound 2, compound $\mathbf{6}(65 \%)$ was obtained as a white solid. ${ }^{1} \mathrm{H}$ NMR (400 MHz, $\left.\mathrm{CDCl}_{3}\right) \delta 11.57$ (s, 1H), 10.55 (s, 1H), 8.28 (s, 2H), $8.00(\mathrm{~s}, 1 \mathrm{H})$, $7.57(\mathrm{~d}, J=7.1 \mathrm{~Hz}, 2 \mathrm{H}), 7.29-7.25(\mathrm{~m}, 2 \mathrm{H}), 7.10(\mathrm{t}, J=7.3 \mathrm{~Hz}, 1 \mathrm{H}), 4.60(\mathrm{~s}, 2 \mathrm{H}) ;{ }^{13} \mathrm{C} \mathrm{NMR}$ $\left(125 \mathrm{MHz}, \mathrm{CD}_{3} \mathrm{OD}\right) \delta 169.1,164.5,139.0,135.4,133.2$ (q, $\left.{ }^{2} J_{\mathrm{C}, \mathrm{F}}=33.8 \mathrm{~Hz}\right), 129.9,128.9,126.3$, 125.7, $124.5\left(\mathrm{q},{ }^{1} J_{\mathrm{C}, \mathrm{F}}=271.9 \mathrm{~Hz}\right), 121.3,76.6 ;{ }^{19} \mathrm{~F} \mathrm{NMR}\left(376 \mathrm{~Hz}, \mathrm{CDCl}_{3}\right) \delta-63.0$; HRMS (ESI) for $\mathrm{C}_{17} \mathrm{H}_{13} \mathrm{~F}_{6} \mathrm{~N}_{2} \mathrm{O}_{3}\left(\mathrm{M}+\mathrm{H}^{+}\right)$: calcd 407.0825, found 407.0842 .

\section{Ion transport assays and mechanism studies}

\subsection{General procedures}

These procedures refer to the ion transport assays and mechanism studies in the main text. EYPC (egg yolk L- $\alpha$ phosphatidylcholine) was purchased from Avanti and was stored at $-20^{\circ} \mathrm{C}$ in chloroform/methanol solution. Intravesicular and external solutions can vary for the different experiments (see caption of figures). Ion transport activities were monitored by fluorescent probes, and 5\% Triton X-100 was used as a detergent.

\section{Preparation of HPTS-loaded vesicles}

Egg yolk L- $\alpha$-phosphatidylcholine (EYPC, $25 \mathrm{mg} / \mathrm{mL})$ solution $(2 \mathrm{~mL})$ was concentrated in vacuo and then dried under a high vacuum for at least $3 \mathrm{~h}$. The lipid film was rehydrated in extravesicular buffer $(0.65 \mathrm{~mL})$, which contained $10 \mathrm{mM}$ HEPES, 100 or $75 \mathrm{mM} \mathrm{M} \mathrm{n}(\mathrm{M}=$ $\mathrm{Na}^{+}, \mathrm{K}^{+} ; \mathrm{X}=\mathrm{Cl}^{-}, \mathrm{SO}_{4}{ }^{2-}$ ), $0.1 \mathrm{mM}$ 8-hydroxy-1,3,6-pyrenetrisulfonate (HPTS) buffered at $\mathrm{pH}$ 6.8 , for $2 \mathrm{~h}$. During rehydration, the suspension was subjected to 5 freeze-thaw cycles, in which the suspension was frozen in liquid nitrogen, followed by thawing in a water bath at room temperature. The suspension $(0.5 \mathrm{~mL})$ was then submitted to 25 high-pressure extrusions at room temperature through a $100 \mathrm{~nm}$ polycarbonate membrane. LUV suspension was formed with an average diameter of $100 \mathrm{~nm}$ and then passed through size exclusion chromatography (stationary phase: Sephadex G-50; mobile phase: buffer B containing $10 \mathrm{mM}$ HEPES at pH 6.8 
and 100 or $\left.75 \mathrm{mM} \mathrm{M} \mathrm{X}\left(\mathrm{M}=\mathrm{Na}^{+}, \mathrm{K}^{+} ; \mathrm{X}=\mathrm{Cl}^{-}, \mathrm{SO}_{4}{ }^{2-}\right)\right)$ to remove extravesicular dye. The LUV suspension was diluted with elusion buffer $(5 \mathrm{~mL})$ to give a stock solution with a lipid concentration of $10 \mathrm{mM}$ (assuming 100\% of lipid was incorporated into liposomes) and stored at $4^{\circ} \mathrm{C}$ for less than 4 days.

\section{Base-pulsed HPTS assay}

HPTS-loaded LUV suspension $(100 \mu \mathrm{L})$ prepared as described above was added in isotonic HEPES buffer $(1.9 \mathrm{~mL})$ and placed into a fluorometric cuvette. HPTS fluorescence was monitored with excitation at 403 and $460 \mathrm{~nm}$, and emission at $510 \mathrm{~nm}$. At t $=100 \mathrm{~s}$, DMSO solution of the test compounds $(20 \mu \mathrm{L})$ and $0.5 \mathrm{M} \mathrm{NaOH} / \mathrm{KOH}$ aqueous solution $(20 \mu \mathrm{L})$ were added through an injection port. Addition of the base caused about $1 \mathrm{pH}$ unit increase in the extravesicular buffer. At $\mathrm{t}=500 \mathrm{~s}, 40 \mu \mathrm{L}$ of $5 \%$ Triton $\mathrm{X}-100$ was added to lyse the liposomes. The fluorescence ratio of $\mathrm{F}_{460} / \mathrm{F}_{403}$ of initial $100 \mathrm{~s}$ was set as $0 \%$ ion transport and the final fluorescence ratio of $\mathrm{F}_{460} / \mathrm{F}_{403}$ induced by Triton $\mathrm{X}-100$ was set as $100 \%$ ion transport. DMSO or other solvents as indicated was used as control.

$$
\begin{aligned}
& \mathrm{F}_{460} / \mathrm{F}_{403}=I \text {, } \\
& I_{\text {rel }} \%=\left[\left(I_{\mathrm{t}}-I_{0}\right) /\left(I_{\max }-I_{0}\right)\right] \times 100 \%
\end{aligned}
$$

\section{Preparation of SPQ-loaded EYPC vesicles}

Egg yolk L- $\alpha$-phosphatidylcholine (EYPC, $25 \mathrm{mg} / \mathrm{mL})$ solution $(2 \mathrm{~mL})$ was concentrated in vacuo and dried under high vacuum for at least $3 \mathrm{~h}$. The lipid film was rehydrated in buffer $\mathrm{A}$ $(0.65 \mathrm{~mL})$, which contained $10 \mathrm{mM}$ HEPES at $\mathrm{pH}=6.8,200 \mathrm{mM} \mathrm{NaNO}_{3}$ and $0.5 \mathrm{mM} \mathrm{SPQ}$, for $2 \mathrm{~h}$. During rehydration, the suspension was subjected to 5 freeze-thaw cycles, in which the suspension was frozen in liquid nitrogen, followed by thawing in a water bath at room temperature. The suspension $(0.5 \mathrm{~mL})$ was submitted to high-pressure extrusion at room temperature for 25 extrusions through a $100 \mathrm{~nm}$ polycarbonate membrane. LUV suspension was formed with an average diameter of $100 \mathrm{~nm}$, and then passed through size exclusion chromatography (stationary phase: Sephadex G-50; mobile phase: extravesicular buffer B contained $10 \mathrm{mM}$ HEPES at $\mathrm{pH}=6.8$ and $200 \mathrm{mM} \mathrm{NaCl}$ )) to remove extravesicular dye. The LUV suspension was diluted with elusion buffer $(5 \mathrm{~mL})$ to give a stock solution with a lipid concentration of $10 \mathrm{mM}$ (assuming 100\% of lipid was incorporated into liposomes) and stored at $4^{\circ} \mathrm{C}$ for less than 4 days. 


\section{SPQ assay}

SPQ-loaded vesicles $(100 \mu \mathrm{L})$ prepared as described above were suspended in extravesicular HEPES buffer B (1.9 mL) contained $200 \mathrm{mM} \mathrm{NaCl}$ and placed into a fluorometric cuvette. SPQ fluorescence was monitored with excitation at $360 \mathrm{~nm}$ and emission at $430 \mathrm{~nm}$. At $100 \mathrm{~s}$, $\mathrm{MeOH}$ solution of ion transporters $(20 \mu \mathrm{L})$ was added through an injection port. $\mathrm{MeOH}$ was used as control. The fluorescence decrease indicates the chloride influx. $F_{\mathrm{t}}=$ fluorescence intensity at time $\mathrm{t}, F_{0}=$ the average fluorescence intensity before the addition of compounds.

\section{Safranin O membrane potential assay}

Liposomes encapsulated with $100 \mathrm{mM} \mathrm{KCl}$ and $10 \mathrm{mM}$ HEPES buffered at $\mathrm{pH} 7.4$ were prepared as described above. Liposomes $(100 \mu \mathrm{L})$ were suspended in a buffer $(1.9 \mathrm{~mL})$ contained $100 \mathrm{mM} \mathrm{NaCl}$ or $100 \mathrm{mM} \mathrm{KCl}$ (for no potassium gradient), $100 \mathrm{nM}$ safranin $\mathrm{O}$ and $10 \mathrm{mM}$ HEPES buffered at $\mathrm{pH}$ 7.4. Safranin O fluorescence was monitored with excitation at $522 \mathrm{~nm}$ and emission at $581 \mathrm{~nm}$. At $\mathrm{t}=50 \mathrm{~s}$, DMSO solution $(20 \mu \mathrm{L})$ of the compound at the concentration of $5 \mu \mathrm{M}$ was added through an injection port. $F_{\mathrm{t}}=$ fluorescence intensity at time $\mathrm{t}, F_{0}=$ the average fluorescence intensity before the addition of the compound.

\section{Preparation of carboxyfluorescein-loaded vesicles}

Egg yolk L- $\alpha$-phosphatidylcholine (EYPC, $25 \mathrm{mg} / \mathrm{mL})$ solution $(2 \mathrm{~mL})$ was concentrated in vacuo and then dried under a high vacuum for at least $3 \mathrm{~h}$. The lipid film was rehydrated in buffer A $(0.65 \mathrm{~mL})$ contained $10 \mathrm{mM}$ HEPES at $\mathrm{pH}=7.4,100 \mathrm{mM} \mathrm{NaCl}$, and $50 \mathrm{mM}$ carboxyfluorescein (CF) for $2 \mathrm{~h}$. During rehydration, the suspension was subjected to 5 freezethaw cycles, in which the suspension was frozen in liquid nitrogen, followed by thawing in a water bath at room temperature. The suspension $(0.5 \mathrm{~mL})$ was submitted to high-pressure extrusion at room temperature for 25 extrusions through a $0.1 \mu \mathrm{m}$ polycarbonate membrane. LUV suspension was formed with an average diameter of $100 \mathrm{~nm}$ and then passed through size exclusion chromatography (stationary phase: Sephadex G-50; mobile phase: extravesicular buffer containing $10 \mathrm{mM}$ HEPES at $\mathrm{pH}=7.4$ and $100 \mathrm{mM} \mathrm{NaCl}$ ) to remove extravesicular dye. The LUV suspension was diluted with elusion buffers $(5 \mathrm{~mL})$ to give a stock solution with a lipid concentration of $10 \mathrm{mM}$ (assuming $100 \%$ of lipid was incorporated into liposomes) and stored at $4^{\circ} \mathrm{C}$ for less than 4 days. 


\section{Carboxyfluorescein release assay}

Typically, CF-loaded liposomes $(100 \mu \mathrm{L})$ prepared as described above were suspended in a buffer $(1.9 \mathrm{~mL})$ contained $100 \mathrm{mM} \mathrm{NaCl}$ and $10 \mathrm{mM}$ HEPES at $\mathrm{pH}=7.4$, and placed into a fluorometric cuvette. CF fluorescence was monitored with excitation at $492 \mathrm{~nm}$ and emission at $514 \mathrm{~nm}$. At t $=100 \mathrm{~s}, 20 \mu \mathrm{L}$ of DMSO solution of the ion transporters was added through an injection port. At the end of the experiment, 5\% Triton X-100 $(20 \mathrm{uL})$ was added to lyse the liposomes. The final emission intensities monitored at $514 \mathrm{~nm}$ were normalized to $100 \%$ of transport. The fractional CF release $\left(I_{\text {rel }}\right)$ was calculated as follows: $I_{\mathrm{t}}=$ fluorescence intensity at time $\mathrm{t}, I_{0}=$ the average of fluorescence intensity before the addition of compounds and $I_{\max }$ $=$ fluorescence intensity after addition of detergent.

$$
I_{\mathrm{rel}}=\left(I_{\mathrm{t}}-I_{0}\right) /\left(I_{\mathrm{t}}-I_{\max }\right)
$$

\section{Transport behaviors in the presence of FCCP or valinomycin}

In HPTS assay, the extravesicular addition of a controlled amount of base will result in $\mathrm{pH}$ gradient across the bilayer membrane, which drives the ion transporter to facilitate proton efflux or hydroxide influx to generate membrane potential. If the ion transporter can transport another cation or anion $\left(\mathrm{H}^{+} / \mathrm{M}^{+}\right.$or $\mathrm{OH}^{-} / \mathrm{A}^{-}$antiport and $\mathrm{H}^{+} / \mathrm{A}^{-}$or $\mathrm{M}^{+} / \mathrm{OH}^{-}$symport mechanisms are possible) to balance the membrane potential, the $\mathrm{pH}$ may continuously change.

Valinomycin is a natural potassium ionophore, which can form a cationic complex with $\mathrm{K}^{+}$, and then passes through the lipid membrane, releases $\mathrm{K}^{+}$at the other interface (usually with lower $\mathrm{K}^{+}$concentration), and eventually, uncomplexed valinomycin travels back. FCCP is a proton transporter, which can only facilitate proton translocation in the lipid bilayers. In the conventional HPTS assay, the detected activity of $\mathrm{H}^{+}$transport rate of the test compound decreases with increased $\mathrm{H}^{+}$selectivity, because the rate of the disfavored $\mathrm{M}^{+}$influx limited the fluorescence change of HPTS. However, with valinomycin, a disfavored $\mathrm{M}^{+}$influx can be accelerated. Increasing activity in the presence of valinomycin identifies transporters with $\mathrm{H}^{+}>$ $\mathrm{M}^{+}$selectivity. Alternatively, increasing activity in the presence of FCCP identifies transporters with $\mathrm{M}^{+}>\mathrm{H}^{+}$selectivity.

HPTS-loaded LUV suspension $(100 \mu \mathrm{L})$ prepared as described above was added in isotonic HEPES buffer $(1.9 \mathrm{~mL})$ and placed into a fluorometric cell. HPTS fluorescence was excited at 403 and $460 \mathrm{~nm}$ alternatively, and the emission was monitored at $510 \mathrm{~nm}$. At t $=50 \mathrm{~s}$, DMSO 
solution $(20 \mu \mathrm{L})$ of the transporter, FCCP or valinomycin was added through an injection port, immediately followed by the addition of $0.5 \mathrm{M} \mathrm{NaOH}$ or $\mathrm{KOH}$ aqueous solution $(20 \mu \mathrm{L})$. Addition of the base caused about $1 \mathrm{pH}$ unit increase in the extravesicular buffer. At $\mathrm{t}=250 \mathrm{~s}$, $5 \%$ Triton X-100 $(40 \mu \mathrm{L})$ was added to lyse the liposomes. The fluorescence of the initial $50 \mathrm{~s}$ was set as $0 \%$ ion transport and the final fluorescence change induced by Triton X-100 was set as $100 \%$ ion transport. DMSO was used as a control.

\title{
$2.2 \mathrm{pK}_{\mathrm{a}}$ determination
}

The $\mathrm{pK}_{\mathrm{a}}$ values of aminoxy acid $\mathrm{NH}$ of compounds $\mathbf{1}$ and $\mathbf{2}$ were calculated according to the reported method ${ }^{2}$, by monitoring absorbance changes in the UV/Vis spectra as a function of variations in $\mathrm{pH}$ of phosphate buffer. Compounds dissolved in $\mathrm{MeOH}(10 \mathrm{mM})$ were added into phosphate buffer $(0.1 \mathrm{M})$ with different $\mathrm{pH}$ values (from 2 to 11 ) to give the final concentration of $30 \mu \mathrm{M}$. The UV/Vis spectra were recorded in a CARY 50 bio UV/Visible spectrophotometer at $25^{\circ} \mathrm{C}$. Standard $10 \mathrm{~mm}$ quartz glass cells were used. The $\mathrm{pK}_{\mathrm{a}}$ values were determined from a plot of $\log$ (ionization ratio) vs $\mathrm{pH}$ (Eq.1). For compound 1, the absorbance at $260 \mathrm{~nm}$ was used. AA- was take at $\mathrm{pH}=11.01$, AAH was take at $\mathrm{pH}=2.22$. For compound 2, the absorbance at $230 \mathrm{~nm}$ was used. AA- was take at $\mathrm{pH}=11.01, \mathrm{AAH}$ was take at $\mathrm{pH}=$ 2.22 .

\author{
A: Absorbance at each $\mathrm{pH}$ \\ $\mathrm{AA}^{-}$: Absorbance of the deprotonated form \\ AAH: Absorbance of the protonated form \\ $\log \left[\left(\mathrm{A}-\mathrm{AA}^{-}\right) /(\mathrm{AAH}-\mathrm{A})\right]=-\mathrm{pH}+\mathrm{pKa}($ Eq. 1)
}


a

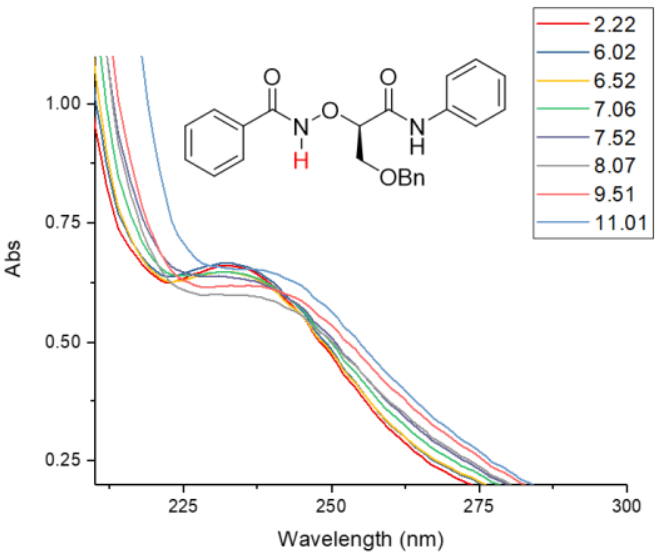

b

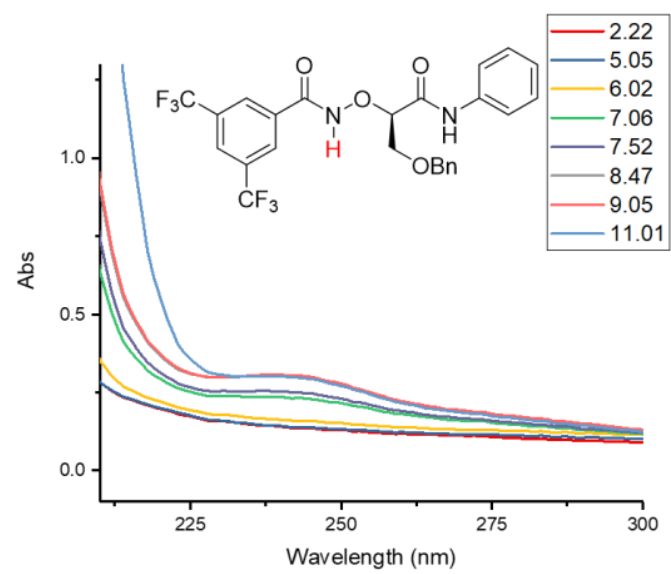

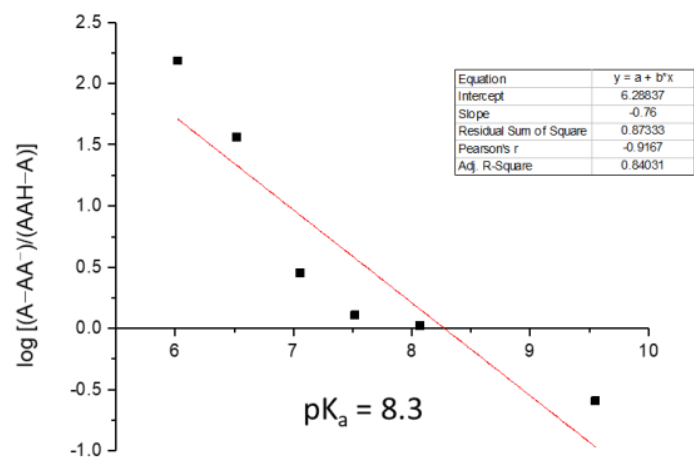

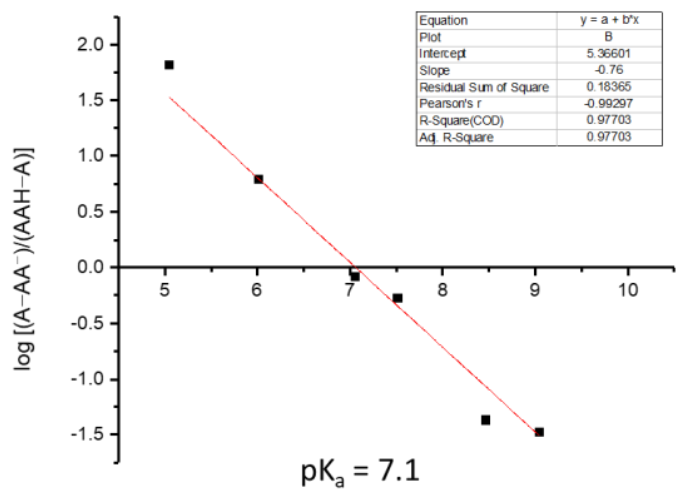

Figure S1. UV/Vis spectra and $\log ($ ionization ratio) vs $\mathrm{pH}$ for $\mathbf{a}$, compound $\mathbf{1}$ and $\mathbf{b}$, compound 2 as a function of $\mathrm{pH}$ in $0.1 \mathrm{M}$ phosphate buffer at $25^{\circ} \mathrm{C}$.

\section{$2.3{ }^{39} \mathrm{~K}$ NMR studies}

The stoichiometry of ion complex between $\mathrm{K}^{+}$and compound $\mathbf{2}$ was determined according to the literature reported procedures ${ }^{3}$. In brief, LUVs with a diameter of $1 \mu \mathrm{m}$ were prepared with the same procedure described above. Both intravesicular and extravesicular buffers contained $10 \mathrm{mM}$ HEPES $\mathrm{pH}=7.4$ and the same concentration of $\mathrm{K}^{+}(75 \mathrm{mM}, 100 \mathrm{mM}$ and $125 \mathrm{mM})$. The intravesicular anion was $\mathrm{Cl}^{-}$and the external anion was triphosphate (pppi ${ }^{5-}$ ). NMDG chloride was added in the extravesicular buffer to balance the ionic concentration on both sides of the membrane. $\mathrm{Tb}\left(\mathrm{NO}_{3}\right)_{3}$ at the final concentration of $5 \mathrm{mM}$ was added to the extravesicular buffer to create a chemical shift difference between intravesicular and extravesicular $\mathrm{K}^{+}$. Lifetimes $T$ was calculated from the equation $1 / T=($ line broadening $) \times л$. The line broadening was calculated from the observed linewidth of inner $\mathrm{K}^{+}$in the presence of compound 2 minus the original linewidth. As shown in Figure S3, experiments with liposomes loaded different concentrations of $\mathrm{KCl}(75 \mathrm{mM}, 100 \mathrm{mM}$ and $1501 \mathrm{mM})$ were conducted. For every 
concentration of $\mathrm{K}^{+}$studied, 1/T varies linearly with compound to lipid ratio [L] ([compound 2] : [EYPC]), which indicated the first-order rate constant for $\mathrm{K}^{+}$efflux $1 / T=\mathrm{k}[\mathrm{L}]$. This linear relationship confirmed the 1:1 complex between $\mathrm{K}^{+}$and compound 2 .

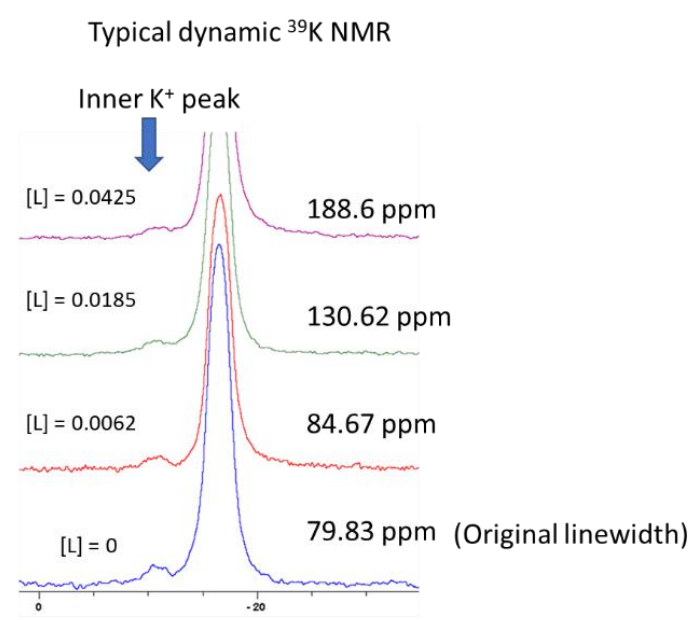

Figure S2. Representative dynamic ${ }^{39} \mathrm{~K}$ NMR spectra. Liposomes containing $75 \mathrm{mM} \mathrm{KCl}$ was used. [L] $=$ [compound 2]/[lipid].
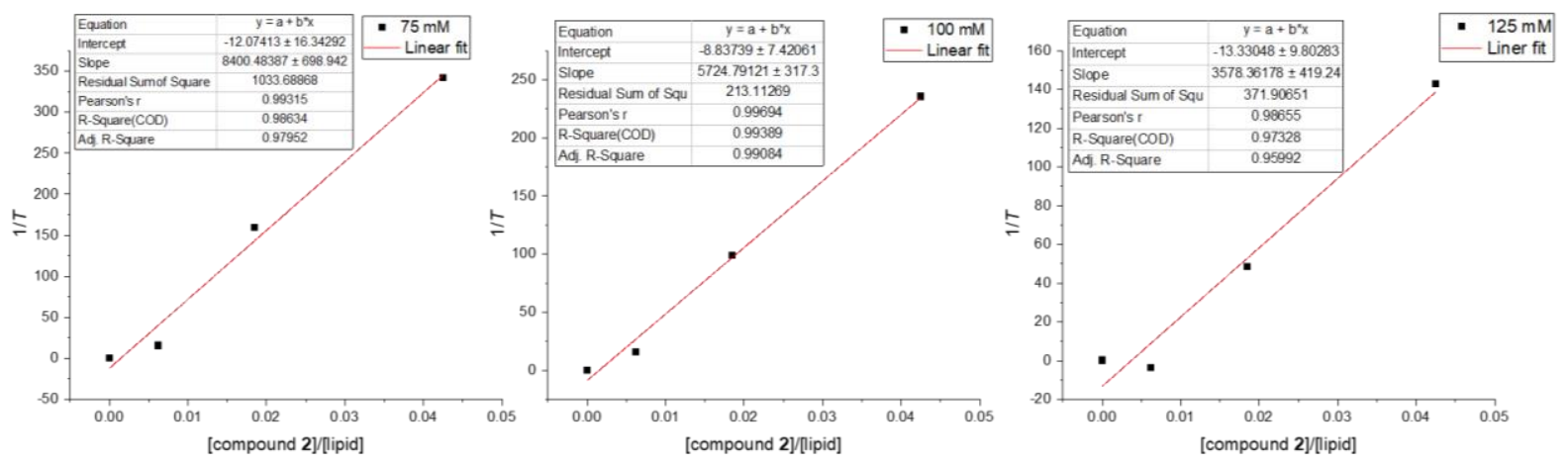

Figure S3. Graph of 1/T vs [L], LUVs encapsulated 75, 100 and $125 \mathrm{mM}$ of $\mathrm{K}^{+}$were used.

\section{$2.4 \mathrm{~K}^{+} / \mathrm{Na}^{+}$selectivity studies}

EYPC liposomes $(100 \mu \mathrm{L})$ prepared according to the procedures described above were immersed into extravesicular solution $\left(1.9 \mathrm{~mL}\right.$ ) containing $75 \mathrm{mM} \mathrm{K}_{2} \mathrm{SO}_{4}$ (for $\mathrm{K}^{+}$transport) or $75 \mathrm{mM} \mathrm{Na}_{2} \mathrm{SO}_{4}$ (for $\mathrm{Na}^{+}$transport). The sensitivity of transporters to extravesicular cation indicates their ability to differentiate potassium and sodium ions. The intravesicular solution contained $0.1 \mathrm{mM}$ HPTS, $10 \mathrm{mM}$ HEPES, and $75 \mathrm{mM} \mathrm{K}_{2} \mathrm{SO}_{4}$, buffered at $\mathrm{pH} 6.8$; the extravesicular solution contained $10 \mathrm{mM}$ HEPES at pH 6.8, $75 \mathrm{mM} \mathrm{K}_{2} \mathrm{SO}_{4}$ (blue) or $\mathrm{Na}_{2} \mathrm{SO}_{4}$ (Red). At $\mathrm{t}=100 \mathrm{~s}$, compound 2 or DMSO (as blank) was injected into extravesicular buffer, immediately followed by the addition of $\mathrm{KOH}$ or $\mathrm{NaOH}$ to trigger a $\mathrm{pH}$ gradient. Liposomes 
were lysed at $500 \mathrm{~s}$ with 5\% Triton X-100 to measure the maximum fluorescence change. Hill equation $\mathrm{Y}=1 /\left(1+\left(\mathrm{EC}_{50} /[\mathrm{C}]\right)^{\mathrm{n}}\right)$ was employed to calculate $\mathrm{EC}_{50}$ and Hill coefficient $\mathrm{n}$ for the transport of potassium and sodium ions of synthetic ion transporters. Y was calculated for each curve using the normalized value of $I_{460} / I_{403}$, from 0 (ratio for the blank) to 1 (highest ratio obtained, i.e. a plateau). $\mathrm{C}$ is the concentration of transporter used. Experimental data were analyzed by a non-linear least-square fitting method ${ }^{4}$.

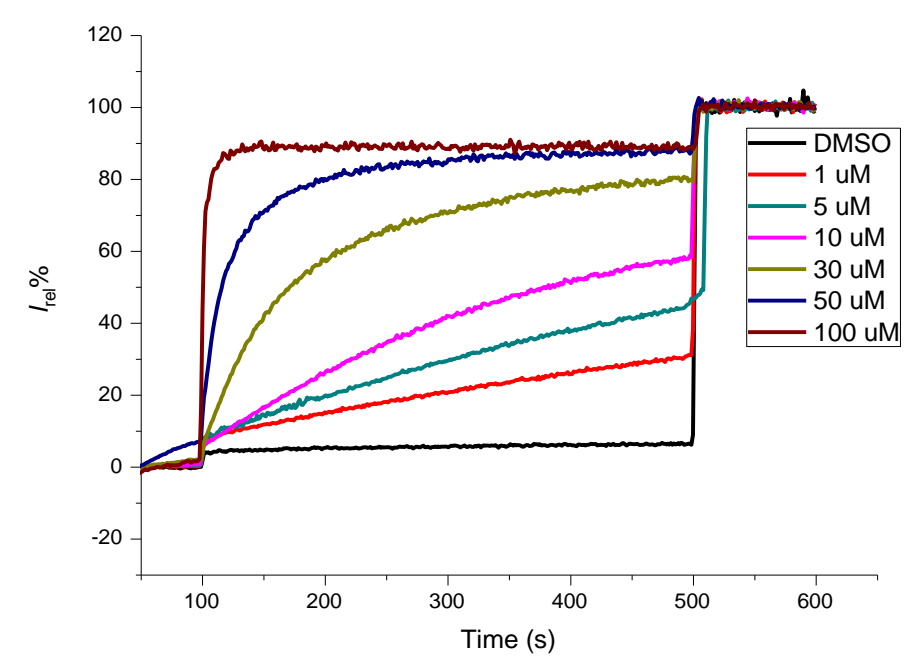

Figure S4. $\mathrm{K}^{+}$and $\mathrm{H}^{+} / \mathrm{OH}^{-}$transport induced by compound 2 at the final concentration of 1, 5, $10,30,50$, and $100 \mu \mathrm{M}$. The intravesicular solutions contained $0.1 \mathrm{mM}$ HPTS, $75 \mathrm{mM} \mathrm{K}_{2} \mathrm{SO}_{4}$ and $10 \mathrm{mM}$ HEPES, buffered at $\mathrm{pH}$ 6.8. And extravesicular solutions contained $75 \mathrm{mM} \mathrm{K}_{2} \mathrm{SO}_{4}$ and $10 \mathrm{mM}$ HEPES, buffered at pH 6.8. At $100 \mathrm{~s}, 20 \mu \mathrm{L}$ of DMSO (as blank) or DMSO solution of compound 2 was injected into extravesicular buffer, immediately followed by the addition of $\mathrm{KOH}$ to trigger a $\mathrm{pH}$ gradient. Liposomes were lysed at $500 \mathrm{~s}$ with $5 \%$ Triton $\mathrm{X}-100$ to measure maximum fluorescence change. 


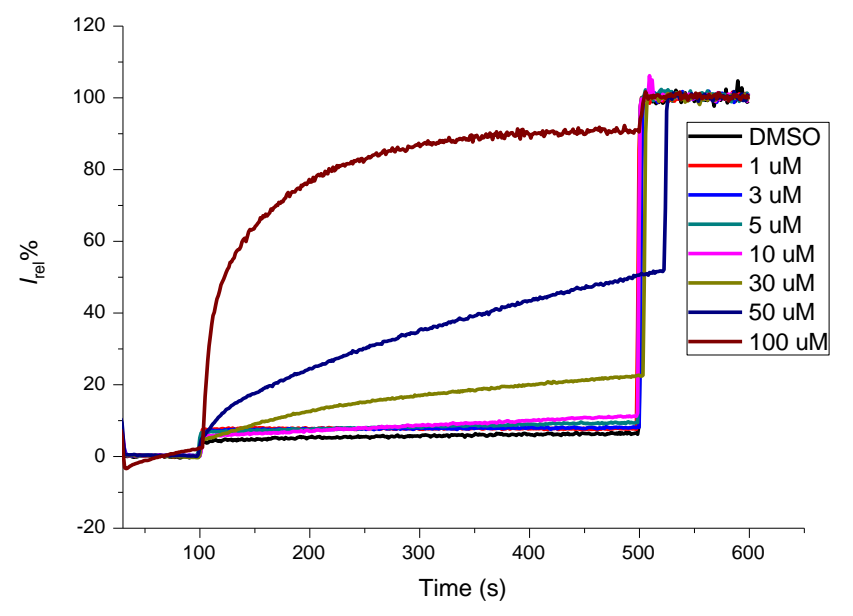

Figure S5. $\mathrm{Na}^{+}$and $\mathrm{H}^{+} / \mathrm{OH}^{-}$transport induced by compound 2 at the final concentration of 1 , 3, 5, 10, 30, 50, and $100 \mu \mathrm{M}$. The intravesicular solutions contained $0.1 \mathrm{mM}$ HPTS, $75 \mathrm{mM}$ $\mathrm{K}_{2} \mathrm{SO}_{4}$ and $10 \mathrm{mM}$ HEPES, buffered at $\mathrm{pH}$ 6.8. And extravesicular solutions contained $75 \mathrm{mM}$ $\mathrm{Na}_{2} \mathrm{SO}_{4}$ and $10 \mathrm{mM}$ HEPES, buffered at pH 6.8. At $100 \mathrm{~s}, 20 \mathrm{uL}$ of DMSO (as blank) or DMSO solution of compound $\mathbf{2}$ was injected into extravesicular buffer, immediately followed by the addition of $\mathrm{NaOH}$ to trigger a $\mathrm{pH}$ gradient. Liposomes were lysed at $500 \mathrm{~s}$ with $5 \%$ Triton $\mathrm{X}$ 100 to measure maximum fluorescence change.

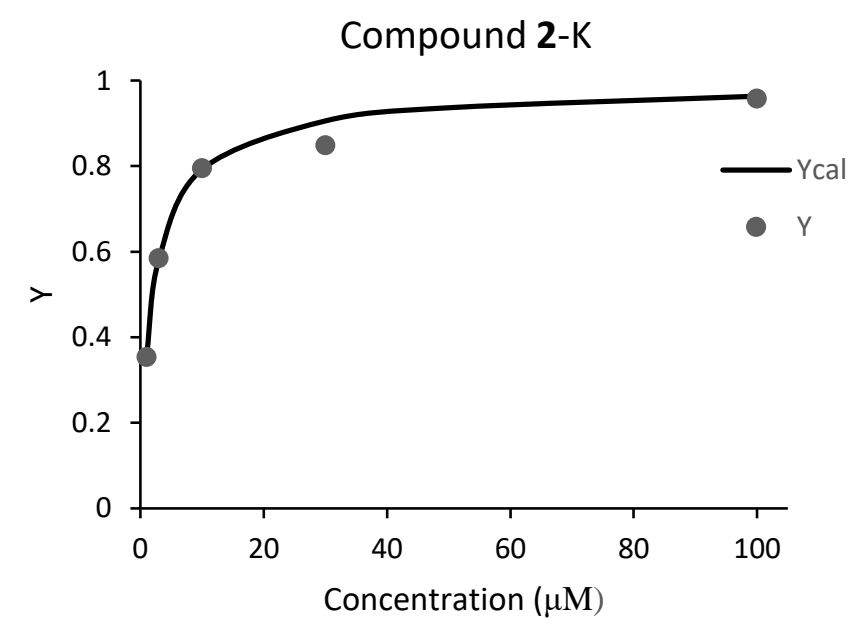

Figure S6. Fractional activity $\mathrm{Y}=1 /\left(1+\left(\mathrm{EC}_{50} /[\mathrm{C}]\right)^{\mathrm{n}}\right)$ to calculate $\mathrm{EC}_{50}$ and Hill coefficient $\mathrm{n}$ for the transport of $\mathrm{K}^{+}$cations of compound 2 : $\mathrm{EC}_{50}=2.02 \mu \mathrm{M}, \mathrm{n}=0.84$. Solid circles $(\bullet)$ are experimental data, and the curves are the best-calculated fit from the Hill equation. 


\section{Compound 2-Na}

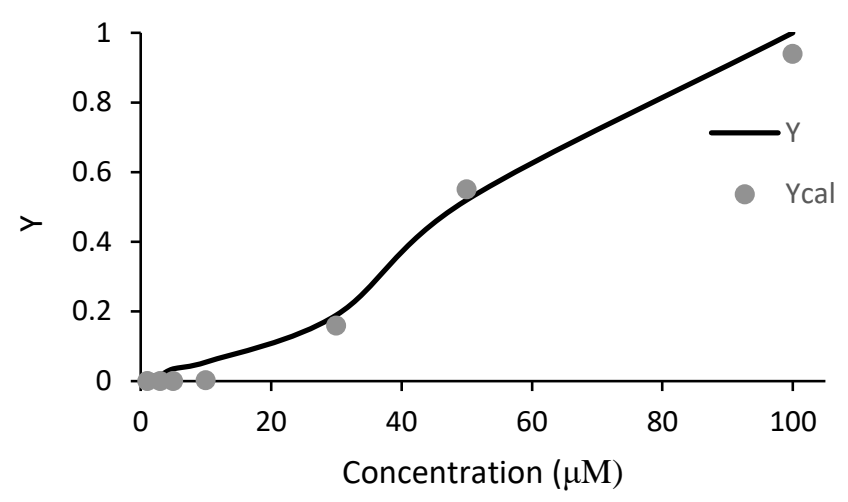

Figure S7. Fractional activity $\mathrm{Y}=1 /\left(1+\left(\mathrm{EC}_{50} /[\mathrm{C}]\right)^{\mathrm{n}}\right)$ to calculate $\mathrm{EC}_{50}$ and Hill coefficient $\mathrm{n}$ for the transport of $\mathrm{Na}^{+}$cations of compound 2: $\mathrm{EC}_{50}=47.26 \mu \mathrm{M}, \mathrm{n}=3.66$. Solid circles $(\bullet)$ are experimental data, and the curves are the best-calculated fit from the Hill equation.

The $\mathrm{K}^{+} / \mathrm{Na}^{+}$selectivity of compound 2 was also determined by the ratio of the fractional ion transport activity $\left(\mathrm{R}_{\mathrm{M}}^{+}\right)$at a concentration where the $\mathrm{K}^{+}$transport activity reaches its highest capacity $^{5-6}$. In brief, EYPC liposomes $(100 \mu \mathrm{L})$ prepared according to the procedures described above were immersed into extravesicular solution $\left(1.9 \mathrm{~mL}\right.$ ) containing $75 \mathrm{mM} \mathrm{K}_{2} \mathrm{SO}_{4}$ (for $\mathrm{K}^{+}$ transport) or $75 \mathrm{mM} \mathrm{Na}_{2} \mathrm{SO}_{4}$ (for $\mathrm{Na}^{+}$transport). At $\mathrm{t}=100 \mathrm{~s}$, compound 2 at the final concentration of $15 \mu \mathrm{M}$ or DMSO (as blank) was injected into extravesicular buffer, immediately followed by the addition of $\mathrm{KOH}$ or $\mathrm{NaOH}$ to trigger a $\mathrm{pH}$ gradient. Liposomes were lysed at $1100 \mathrm{~s}$ with $5 \%$ Triton X-100 to measure the maximum fluorescence change. Y was calculated for each curve using the normalized value of $I_{460} / I_{403}$. The fractional change $\mathrm{R}_{\mathrm{M}}{ }^{+}$ was calculated for each curve using Y at $1100 \mathrm{~s}$ before the addition of Triton X-100, with the ratio of blank that contains only DMSO normalized to 0 .

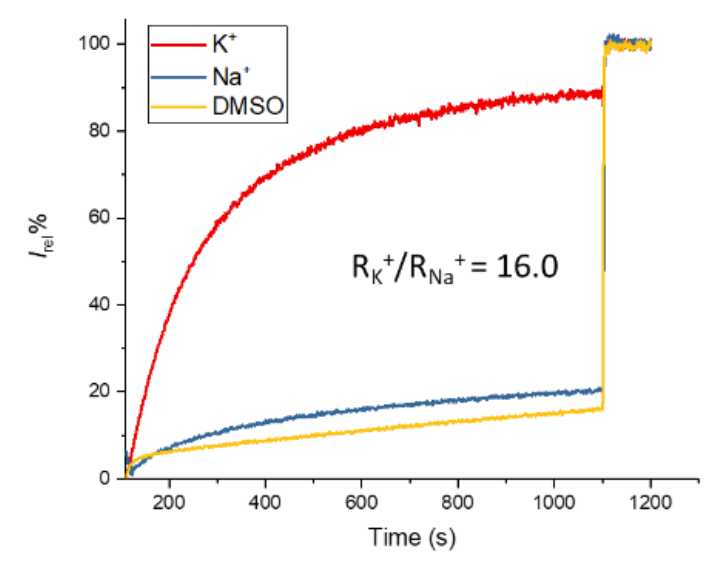

Figure S8. Ratio of fractional transport activities $\mathrm{R}_{\mathrm{K}}^{+} / \mathrm{R}_{\mathrm{Na}}{ }^{+}$of compound 2 . 


\subsection{Selectivity study towards some other alkali metal cations}

The selectivity of compound $\mathbf{2}$ towards some other alkali metal cations was also evaluated using HPTS assay, in which the intravesicular solution contained $100 \mathrm{mM} \mathrm{NaCl}$ and the extravesicular solution contained $100 \mathrm{mM} \mathrm{MCl}(\mathrm{M}=\mathrm{Li}, \mathrm{Na}, \mathrm{K}$, and $\mathrm{Cs})$. Both ion transport is driven by concentration gradient (before $\mathrm{t}=200 \mathrm{~s}$ ) or by $\mathrm{pH}$ gradient (after addition of $20 \mu \mathrm{L}$ of $0.1 \mathrm{~N}$ base at $\mathrm{t}=200 \mathrm{~s}$ ) were investigated. At $\mathrm{t}=30 \mathrm{~s}, 20 \mu \mathrm{L}$ of DMSO solution of compound 2 was added, and at $\mathrm{t}=200 \mathrm{~s}, 20 \mu \mathrm{L}$ of $0.1 \mathrm{M} \mathrm{MOH}(\mathrm{M}=\mathrm{Li}, \mathrm{Na}, \mathrm{K}, \mathrm{Cs})$ was added to generate a $\mathrm{pH}$ gradient. Liposomes were lysed by the addition of Triton X-100 at $\mathrm{t}=500 \mathrm{~s}$.

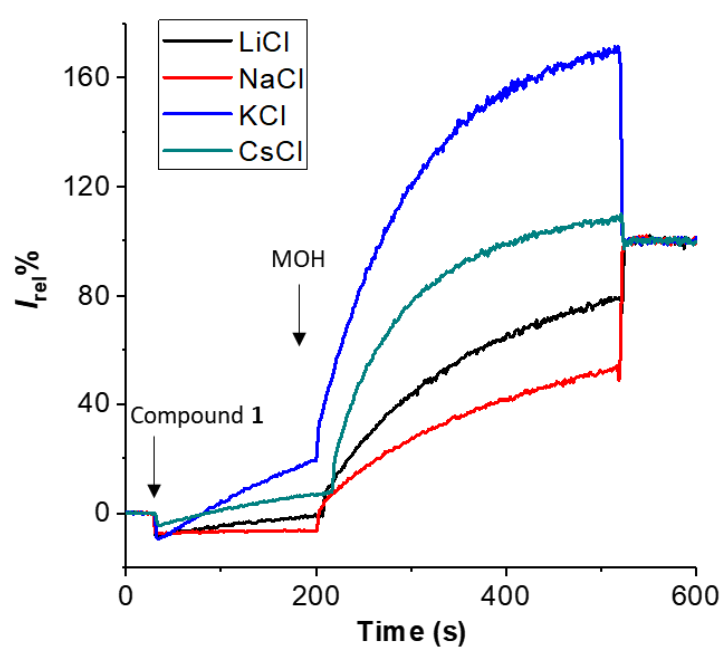

Figure S9. The ion selectivity of compound 2 towards some other alkali metal cations at the concentration of $10 \mu \mathrm{M}$. Liposomes loaded with $100 \mathrm{mM} \mathrm{NaCl}$ and $0.1 \mathrm{mM}$ HPTS were suspended in $100 \mathrm{mM} \mathrm{MCl}$ solutions ( $\mathrm{M}=\mathrm{Li}, \mathrm{Na}, \mathrm{K}$ and $\mathrm{Cs})$.

\subsection{Carboxyfluorescein release study}

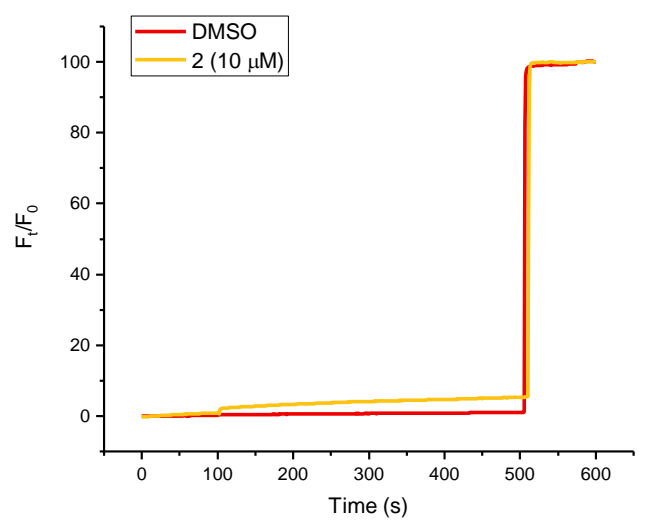

Figure S10. Carboxyfluorescein release assay of compound 2. 


\subsection{EC 50 calculation of proton transport activities}

Valinomycin is a highly selective potassium ionophore. Here, in the presence of valinomycin, the proton transport activities of compound $\mathbf{2}$ at different doses in liposome assays were evaluated. As valinomycin can facilitate $\mathrm{K}^{+}$transport for compensation, that compounds can show their maximum proton transport capabilities.
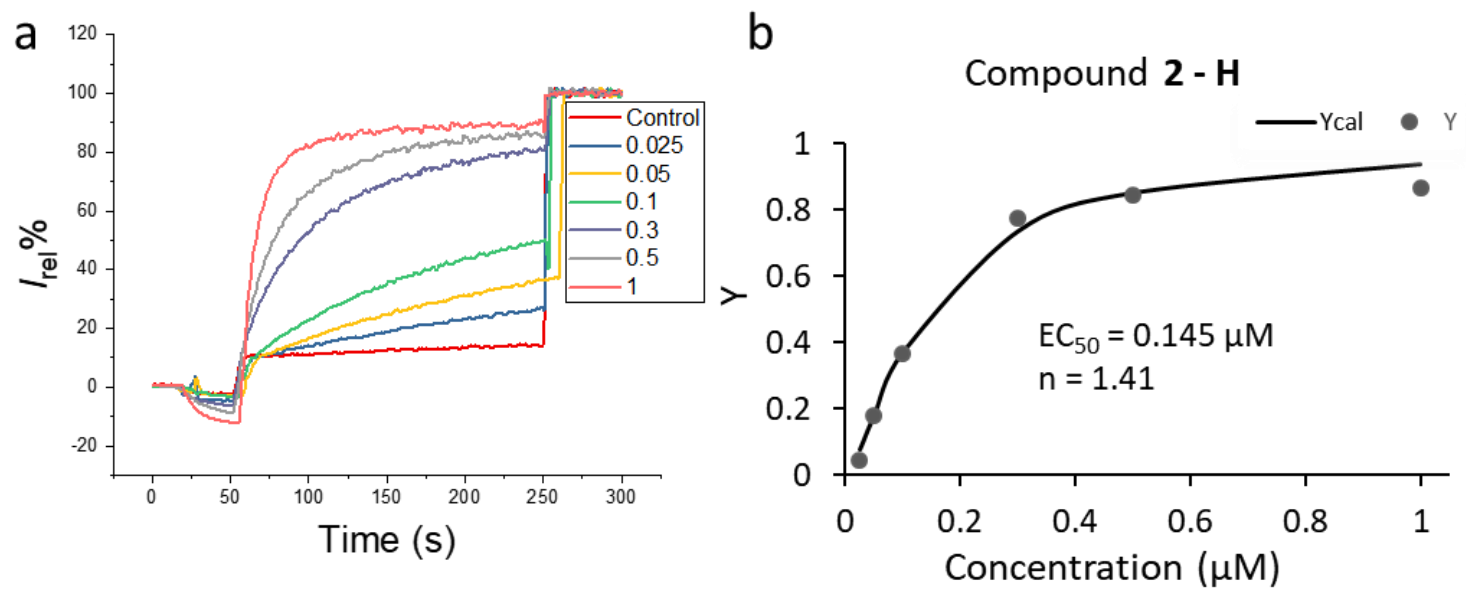

Figure S11. a, Proton transport activity induced by compound 2 in the presence of $25 \mathrm{nM}$ Val. The intravesicular solutions contained $0.1 \mathrm{mM}$ HPTS, $75 \mathrm{mM} \mathrm{K}_{2} \mathrm{SO}_{4}$ and $10 \mathrm{mM}$ HEPES, buffered at $\mathrm{pH}$ 6.8; and extravesicular solutions contained $75 \mathrm{mM} \mathrm{K}_{2} \mathrm{SO}_{4}$ and $10 \mathrm{mM}$ HEPES, buffered at $\mathrm{pH}$ 6.8. At $\mathrm{t}=30 \mathrm{~s}, 20 \mu \mathrm{L}$ of $0.5 \mathrm{M} \mathrm{KOH}$ aqueous solution and $20 \mu \mathrm{L}$ of DMSO (as blank) or DMSO solution of compound 2 were injected into extravesicular buffer. Liposomes were lysed at $500 \mathrm{~s}$ with $5 \%$ Triton X-100 to measure maximum fluorescence change. $\mathbf{b}$, Fractional activity $\mathrm{Y}=1 /\left(1+\left(\mathrm{EC}_{50} /[\mathrm{C}]\right)^{\mathrm{n}}\right)$ to calculate $\mathrm{EC}_{50}$ and Hill coefficient $\mathrm{n}$ for the transport of $\mathrm{H}^{+}$. Solid circles $(\bullet)$ are experimental data, and the curves are the bestcalculated fit from the Hill equation. $\mathrm{EC}_{50}=0.15 \mu \mathrm{M}, \mathrm{n}=1.41$.

\section{Biological studies}

\subsection{Reagents and antibodies}

Reagents. CellTiter-Glo® Luminescent Cell Viability Assay (CellTiter reagent, G7570, Promega), APG-2AM (Potassium probe, Asante Potassium Green-2m, TEF labs), DiSBAC2(3) (Bis-(1,3-Diethylthiobarbituric Acid)Trimethine Oxonol, B413, ThermoFisher), SNARF (5(and-6)-Carboxy SNARFTM-1, Acetoxymethyl Ester, Acetate, C1272, ThermoFisher), Dead Cell Apoptosis Kit with Annexin V Alexa Fluor ${ }^{\mathrm{TM}} 488$ \& Propidium Iodide (PI) (V13245, 
ThermoFisher), JC-1 (Mitochondrial membrane potential probe, T3168, ThermoFisher), MitoTracker ${ }^{\mathrm{TM}}$ Green FM (MTG, M7514, ThermoFisher), LysoTracker ${ }^{\mathrm{TM}}$ Red DND-99 (LTR, L7528, ThermoFisher), Acridine Orange (AO, A6014, Sigma Aldrich), Valinomycin (V0627, Sigma Aldrich), Nigericin (N1495, ThermoFisher), Carbonyl cyanide 4(trifluoromethoxy)phenylhydrazone (FCCP, C2920, ThermoFisher), Oligomycin (75351, ThermoFisher), Antimycin A (A0274, ThermoFisher) and Rotenone (R8875, Sigma Aldrich).

Antibodies. PE-conjugated CD133 (Clone: AC133, Miltenyi Biotec), PARP1/2 (sc-7150, Santa Cruz Biotec), Caspase 9 (\#9520, Cell Signaling Technology), Caspase 3 (ab4051, Abcam), $\beta$-tubulin (\#2146, Cell Signaling), P62 (sc-28359, Santa Cruz Biotec), LC3B (\#3868, Cell Signaling Technology), GAPDH (\#2118, Cell Signaling Technology), COX IV (\#4844, Cell Signaling Technology).

\subsection{Methods for cell cultures and biological experiments}

\section{Cell cultures}

Human ovarian carcinoma cell lines HEYA8 and SKOV3 were grown in Dulbecco's Modified Eagle (DMEM) medium supplemented with $10 \% \mathrm{FBS}$ and $1 \%$ penicillin/streptomycin at $37^{\circ} \mathrm{C}$ in a humidified atmosphere containing $5 \% \mathrm{CO}_{2}$. Isolation and culture of spheres were performed in serum-free stem-cell-selective conditions as previously described ${ }^{7}$. Briefly, 1-2 weeks after plating, non-adherent spherical clusters of cells could be observed and were separated from single cells by low-speed centrifugation. After 8th to 10th passages, the nonadherent spherical clusters of cells appeared as distinct spheres. Using this selection condition, HEYA8 spheres (HEYA8 CSCs) could be enzymatically dissociated and reformed into spheres within 3 days under the stem-cell-selective condition as described in literature ${ }^{8}$. To allow differentiation, dissociated sphere cells were plated on tissue culture plates in medium (MCDB 105: M199=1:1) supplemented with 10\% FBS and 1\% penicillin-streptomycin.

HeLa cells (cervical cancer cells), NIH3T3 cells (mouse fibroblast cells) and HEK293 cells (human embryonic cells) were grown in DMEM medium with high glucose supplemented with $10 \% \mathrm{FBS}$ and $1 \%$ penicillin/streptomycin at $37^{\circ} \mathrm{C}$ in a humidified atmosphere containing $5 \%$ $\mathrm{CO}_{2}$. MDCK cells (Madine Darby Canine kidney cells) were grown in the EMEM medium supplemented with $10 \% \mathrm{FBS}$ and $1 \%$ penicillin/streptomycin at $37^{\circ} \mathrm{C}$ in a humidified atmosphere containing $5 \% \mathrm{CO}_{2}$. 


\section{Statistics}

All data were mean \pm s.e.m., unless otherwise noted. Statistical analysis represents $p$ values obtained from one-way ANOVA or two-sided unpaired Student's t-test where necessary, ns, not significant; $* p<0.05, * * p<0.01, * * * p<0.001, * * * * p<0.0001$.

\section{Measurement of cell viability}

Cells were plated in triplicate in $0.1 \mathrm{~mL}$ full medium in 96-well plates for $24 \mathrm{~h}$. After that, the medium was changed to the freshly prepared medium with various concentrations of test compounds. Cells were incubated for another $48 \mathrm{~h}$. Then the cell viability was measured by CellTiter-Glo® Luminescent Cell Viability reagent according to the manufacture's instruction. The luminescence at $550 \mathrm{~nm}$ was measured using a microplate reader (DTX 880 Multimode Detector, Beckman Coulter). Data were analyzed by GraphPad software 7.00.

\section{Measurement of CSCs viability}

HEYA8 or SKOV3 CSCs $\left(5 \times 10^{4}\right.$ cells $\left./ \mathrm{mL}\right)$ were seeded in triplicate in $10 \mathrm{~mL}$ serum-free MCDB105/M199 = 1/1 medium in 100-mm Petri dish for 7 days to form spheres. Then, test compounds at different concentrations were added. The cells were further incubated at $37^{\circ} \mathrm{C}$ for $48 \mathrm{~h}$. After that cells were collected by centrifugation and the medium was removed. Then $100 \mu \mathrm{L}$ of CellTiter-Glo ${ }^{\circledR}$ Luminescent Cell Viability reagent was added into each tube, which was incubated for $10 \mathrm{~min}$ with shaking. After that, the reagent was transferred into 96-well plates and cell viability was measured using a microplate reader (DTX 880 Multimode Detector, Beckman Coulter).

\section{Measurement of the population of $\mathrm{CD} 133^{+}$cells by FACS}

HEYA8 cells $\left(2.5 \times 10^{4}\right.$ cells $\left./ \mathrm{mL}\right)$ were seeded into $60-\mathrm{mm}$ cell culture dishes in DMEM medium. Cells were incubated at $37^{\circ} \mathrm{C}$ in a humidified atmosphere containing $5 \% \mathrm{CO}_{2}$ for 24 $\mathrm{h}$, followed by the addition of $4 \mathrm{~mL}$ fresh medium or medium containing Paclitaxel (100 $\mathrm{nM})$ or compound $2(15 \mu \mathrm{M})$. Medium containing $0.1 \%$ DMSO was used as a negative control. After 3 days, the medium was removed and cells were washed with cold PBS twice, and then stained with PE-conjugated CD133 antibody according to the manufacturer's instruction. The fluorescence was analyzed by flow cytometry. 


\section{Measurement of the sphere-forming ability}

Dissociated HEYA8 CSCs at the density of $2.5 \times 10^{4}$ cells $/ \mathrm{mL}$ were grown in cell culture dishes with full medium and treated with DMSO or compound 2 at the indicated concentrations for $48 \mathrm{~h}$. Then cells were allowed to recover and grow in fresh medium for 3 days. After that, cells at the density of $5 \times 10^{4}$ cells $/ \mathrm{mL}$ were transferred into low attachment dishes in sphere-forming conditions for 5 days. The number of spheres in each dish was counted.

\section{Measurement of the in vivo tumor-forming ability}

All animal experiments were approved by the Committee on the Use of Live Animals in Teaching and Research (CULATR) at the University of Hong Kong. In vivo tumor-forming ability of cells after treatment with compound $\mathbf{2}$ was evaluated. Paclitaxel was used as a negative control. For this experiment, HEYA8 CSCs were pretreated with $2(4 \mu \mathrm{M})$ or paclitaxel $(0.1 \mu \mathrm{M})$ for 2 days in a suspension medium, respectively. Then cells were allowed to proliferate in full medium in the absence of drugs for 10 days. After that, $10^{6}$ cells were subcutaneously (s.c.) injected into the flank of athymic nude female mice bilaterally. The length and width of a tumor were measured with a caliper for 25 days after injection and tumor volume was calculated as Tumor volume $\mathrm{V}=\left(\pi \times \mathrm{L} \times \mathrm{W}^{2}\right) / 6$, where $\mathrm{L}$ represents the largest tumor diameter and $\mathrm{W}$ represents the perpendicular tumor diameter.

\section{Measurement of the in vivo tumor-size after treatment of compound 2}

For this experiment $10^{6}$ HEYA8 cells in PBS buffer were subcutaneously (s.c.) injected into the flank of athymic nude female mice. Compound $\mathbf{2}$ treatment was initiated with intraperitoneal injection (i.p.) 8 days after tumor seeding. Animals were administered with PBS buffer or compound 2 at the dosage of $5 \mathrm{mg} / \mathrm{kg}$ three days a week. The length and width of a tumor were measured with a caliper for 18 days after injection and tumor volume was calculated as Tumor volume $\mathrm{V}=\left(\pi \times \mathrm{L} \times \mathrm{W}^{2}\right) / 6$, where L represents the largest tumor diameter and $\mathrm{W}$ represents the perpendicular tumor diameter.

\section{Western blotting}

Cells were treated as indicated, then washed twice with PBS buffer and lysed with lysis buffer (0.1\% Triton X-100, $150 \mathrm{mM} \mathrm{NaCl}, 0.1 \mathrm{U}$ Benzonase, Roche EDTA-free protease inhibitor cocktail, $20 \mathrm{mM}$ Tris-HCl, $\mathrm{pH}$ 8.0). Protein extracts were quantified by Pierce BCA Protein Assay Kit with a Nanodrop 2000 (Thermo Fisher Scientific) according to the manufacturer's instruction. Protein lysates $(\sim 50 \mu \mathrm{g} / \mathrm{lane})$ were resolved by hand-cast SDS-PAGE and 
transferred onto poly(vinylidene difluoride) (PVDF) membranes. Membranes were incubated with the membrane blocking solution (Thermo Fisher Scientific) for $1 \mathrm{~h}$. The blots were then probed with the relevant primary antibodies in blocking solution at $4^{\circ} \mathrm{C}$ overnight with gentle agitation. Membranes were washed 5 min with $0.1 \%$ Tween 20/TBS for three times and were incubated with Horseradish Peroxidase (HRP) conjugated secondary antibody for $1 \mathrm{~h}$ at room temperature. Antigens were detected by SuperSignal ${ }^{\mathrm{TM}}$ West Pico PLUS Chemiluminescent Substrate (Thermo Fisher Scientific). The membranes were visualized by chemiluminescent mode of ThermoFischer myECL ${ }^{\mathrm{TM}}$ Imager.

\section{Measurement of plasma membrane potential by FACS}

HEYA8 cells at the density of $5 \times 10^{5}$ cells $/ \mathrm{mL}$ in DMEM medium were seeded into $60-\mathrm{mm}$ cell culture dishes. Cells were incubated at $37^{\circ} \mathrm{C}$ in a humidified atmosphere containing $5 \%$ $\mathrm{CO}_{2}$ for $24 \mathrm{~h}$. After washing with PBS twice, the cells were incubated with $0.5 \mathrm{~mL}$ of trypsinEDTA $\left(0.05 \%\right.$ trypsin, $0.02 \%$ EDTA, Sigma-Aldrich) for $5-10 \mathrm{~min}$ at $37^{\circ} \mathrm{C}$ and collected. Cells were re-suspended in HBSS buffer with bis-oxonol (Bis-(1,3-Diethylthiobarbituric Acid) Trimethine Oxonol) (Thermo Fisher Scientific) at the final concentration of $200 \mathrm{nM}$ and incubated at $37^{\circ} \mathrm{C}$ for $30 \mathrm{~min}$. Cells were centrifuged and washed with PBS buffer, and resuspended in $0.5 \mathrm{~mL}$ HBSS buffer containing 0.1\% DMSO or compound $2(10 \mu \mathrm{M}) 30 \mathrm{~min}$ before analysis by flow cytometry (BD FACSCanto II Analyzer). The fluorescence was measured using an excitation wavelength of $488 \mathrm{~nm}$ and an emission filter $(530 / 30 \mathrm{~nm})$. Quantitative data were obtained using FlowJo and GraphPad Prism software.

\section{Measurement of cytosolic potassium concentration}

HEYA8 cells at the density of $5 \times 10^{5}$ cells $/ \mathrm{mL}$ in DMEM medium were seeded into $60-\mathrm{mm}$ cell culture dishes. Cells were incubated at $37^{\circ} \mathrm{C}$ in a humidified atmosphere containing $5 \%$ $\mathrm{CO}_{2}$ for $24 \mathrm{~h}$. After washing with PBS twice, the cells were incubated with $0.5 \mathrm{~mL}$ of trypsinEDTA $\left(0.05 \%\right.$ trypsin, $0.02 \%$ EDTA, Sigma-Aldrich) for $5-10 \mathrm{~min}$ at $37^{\circ} \mathrm{C}$ and collected. Cells were re-suspended in HBSS buffer with $\mathrm{K}^{+}$probe APG-2AM at the final concentration of $5 \mu \mathrm{M}$ and incubated at $37^{\circ} \mathrm{C}$ for $30 \mathrm{~min}$. Cells were centrifuged and washed with PBS buffer, and re-suspended in $0.5 \mathrm{~mL}$ HBSS buffer containing $0.1 \%$ DMSO or compound $2(10 \mu \mathrm{M}) 30$ min before analyzed by flow cytometry. The fluorescence was measured using an excitation wavelength of $488 \mathrm{~nm}$. Quantitative data were obtained using FlowJo and GraphPad Prism software. 


\section{Mito-SypHer transfection}

Cells at the density of $10^{5}$ cells/mL in DMEM medium were plated into 30-mm cell culture dishes with a glass-bottom (MatTek). Cells were incubated at $37^{\circ} \mathrm{C}$ in a humidified atmosphere containing $5 \% \mathrm{CO}_{2}$ for $24 \mathrm{~h}$. Cells were transfected with $2 \mu \mathrm{g}$ plasmid DNA containing MitoSypHer genes and $6 \mu \mathrm{L} \mathrm{X-tremeGeneHP}$ transfection reagent for $24 \mathrm{~h}$.

\section{Measurement of mitochondrial pH}

Cells transfected with Mito-SypHer were washed with PBS buffer twice, and 0.8 mL HBSS buffer was added. The fluorescence of Mito-SypHer was monitored by a confocal microscope (ZEISS LSM 780). During the kinetics studies, Mito-SypHer was alternately excited at $405 \mathrm{~nm}$ and $488 \mathrm{~nm}$. At $\mathrm{t}=210 \mathrm{~s}, 0.2 \mathrm{~mL}$ HBSS buffer containing $0.1 \%$ DMSO or compound $2(10$ $\mu \mathrm{M})$ was added. Fluorescence ratios $\left(\mathrm{I}_{488} / \mathrm{I}_{405}\right)$ were calculated in ZEN software and analyzed in Excel (Microsoft) and GraphPad Prism software.

\section{Measurement of matrix potassium concentration}

SKOV3 cells at the density of $6 \times 10^{4}$ cells $/ \mathrm{mL}$ in DMEM medium were seeded into $30-\mathrm{mm}$ cell culture dishes with a glass-bottom (MatTek). Cells were incubated at $37^{\circ} \mathrm{C}$ in a humidified atmosphere containing $5 \% \mathrm{CO}_{2}$ for $24 \mathrm{~h}$. After that cells were washed with PBS buffer twice. Mitochondrial potassium probe KS6 was diluted with 10\% (weight/volume) Pluronic F127 (1:1) and added to HBSS buffer at 1:1000 dilution. Cells were incubated in HBSS containing KS6 at the final concentration of $5 \mu \mathrm{M}$ for $1 \mathrm{~h}$. Then the loading buffer was aspirated, and cells were washed twice with PBS buffer. Cells were imaged in $0.8 \mathrm{~mL}$ HBSS buffer using a confocal microscope (ZEISS LSM 780). Potassium probe KS6 was excited at $561 \mathrm{~nm}$. Synthetic cation transporter 2 dissolved in $0.2 \mathrm{~mL}$ HBSS buffer was added during the experiment at given time points and fluorescence images were taken. Quantitative data were obtained using the ZEN and GraphPad Prism software packages.

\section{Measurement of mitochondrial membrane potential by confocal imaging}

HEYA8 cells at the density of $5 \times 10^{4}$ cells $/ \mathrm{mL}$ in DMEM medium were seeded into $30-\mathrm{mm}$ cell culture dishes with a glass-bottom (MatTek). Cells were incubated at $37^{\circ} \mathrm{C}$ in a humidified atmosphere containing $5 \% \mathrm{CO}_{2}$ for $24 \mathrm{~h}$. The medium was aspirated and cells were washed with PBS buffer twice. Then $1 \mathrm{~mL}$ HBSS buffer containing $2.5 \mu \mathrm{M} \mathrm{JC}-1$ was added. Cells were incubated at $37^{\circ} \mathrm{C}$ for $20 \mathrm{~min}$ before the buffer was aspirated. Cells were washed with PBS buffer twice and treated with $0.1 \%$ DMSO or compound 2 at indicated concentrations for 10 
min. Fluorescence was monitored by confocal imaging with ZEISS LSM 780 (Red channel: $\lambda_{\mathrm{ex}}=543 \mathrm{~nm}$, Green channel: $\left.\lambda_{\mathrm{ex}}=488 \mathrm{~nm}\right)$. Quantitative data were obtained using the ZEN and GraphPad Prism software packages.

\section{FACS analysis of CSCs}

After obtained in serum-free medium from ovarian cancer cell lines, spheres were collected by centrifugation. The medium was aspirated and spheres were washed with PBS buffer twice. After that, spheres were trypsinized to afford single cells and washed with PBS buffer. Then cells were incubated with indicated fluorescent probes in HBSS buffer. After staining, cells were centrifuged again and $0.5 \mathrm{~mL}$ cold PBS was added. After pipetting up and down, the single-cell suspension was analyzed by FACS (BD FACSCanto II Analyzer).

\section{Measurement of mitochondrial ROS production}

HEYA8 cells at the density of $5 \times 10^{4}$ cells/mL in DMEM medium were seeded into $30-\mathrm{mm}$ cell culture dishes with a glass-bottom (MatTek). Cells were incubated at $37^{\circ} \mathrm{C}$ in a humidified atmosphere containing $5 \% \mathrm{CO}_{2}$ for $24 \mathrm{~h}$. The medium was aspirated and cells were washed with PBS buffer twice. Then $1 \mathrm{~mL}$ HBSS buffer containing HKSOX-2m in DMF ( $4 \mu \mathrm{M})$ was added. Cells were incubated at $37^{\circ} \mathrm{C}$ for $30 \mathrm{~min}$ before the buffer was aspirated and washed twice with HBSS buffer. Cells were imaged in $0.8 \mathrm{~mL}$ HBSS buffer. Fluorescence was monitored by a confocal microscope (ZEISS LSM 710; Red channel: $\lambda_{\mathrm{ex}}=543 \mathrm{~nm}$ ). At $\mathrm{t}=180$ s, $0.1 \%$ DMF or compound 2 in 0.2 mL HBSS buffer was added to give the final concentration as indicated in Figure 4a. Quantitative data were obtained using the ZEN and GraphPad Prism software.

\section{Observation of mitochondrial morphology and fusion of lysosomes and mitochondria}

HEYA8 cells at the density of $5 \times 10^{4}$ cells/mL in DMEM medium were seeded into $30-\mathrm{mm}$ cell culture dishes with a glass-bottom (MatTek). Cells were incubated at $37^{\circ} \mathrm{C}$ in a humidified atmosphere containing 5\% $\mathrm{CO}_{2}$ for $24 \mathrm{~h}$. The medium was aspirated and cells were washed with PBS buffer twice. Then $1 \mathrm{~mL}$ HBSS buffer containing $100 \mathrm{nM}$ MitoTracker Green and $50 \mathrm{nM}$ LysoTracker Red was added. Cells were incubated at $37^{\circ} \mathrm{C}$ for $30 \mathrm{~min}$. After that, the buffer was aspirated, and cells were washed twice with HBSS buffer. Then cells were treated with $0.1 \%$ DMSO or compound $2(10 \mu \mathrm{M})$ for $1 \mathrm{~h}$. After washing with HBSS buffer once, fluorescence was monitored by confocal imaging on ZEISS LSM 700 (Green channel $\lambda_{\text {ex }}=$ $488 \mathrm{~nm}$, Red channel $\lambda_{\mathrm{ex}}=543 \mathrm{~nm}$ ). Images were further processed by Zen software. 


\section{Oxygen consumption assay}

Cell respiration was measured by using an XF24 Extracellular Flux Analyzer (Seahorse, Bioscience), which measures the oxygen consumption rate (OCR). Adherent HEYA8 cells were seeded at 50000 cells/well in $200 \mu \mathrm{L}$ of their culture medium and incubated for $24 \mathrm{~h}$ at $37^{\circ} \mathrm{C}$ in a humidified atmosphere with $5 \% \mathrm{CO}_{2}$. The medium was then replaced with 670 $\mu \mathrm{L} /$ well of high-glucose DMEM without serum and supplemented with $1 \mathrm{mM}$ sodium pyruvate and $2 \mathrm{mM} \mathrm{L-glutamine.} \mathrm{The} \mathrm{oxygen} \mathrm{consumption} \mathrm{rate} \mathrm{(OCR)} \mathrm{was} \mathrm{measured} \mathrm{with} \mathrm{an}$ extracellular flux analyzer (Seahorse) at preset time intervals upon the preprogrammed additions of the following compounds: Oligomycin to $1 \mu \mathrm{M}$, FCCP to $500 \mathrm{nM}$, Antimycin A and Rotenone to $0.5 \mu \mathrm{M}$ final concentrations.

\section{Annexin V and PI analysis of apoptotic cells by FACS}

HEYA8 cells at the density of $5 \times 10^{4}$ cells $/ \mathrm{mL}$ in DMEM medium were seeded into $60-\mathrm{mm}$ cell culture dishes. Cells were incubated at $37^{\circ} \mathrm{C}$ in a humidified atmosphere containing $5 \%$ $\mathrm{CO}_{2}$ for $24 \mathrm{~h}$ followed by the addition of $4 \mathrm{~mL}$ fresh medium or medium containing compound 2 at various concentrations. Medium containing 0.1\% DMSO was used as a negative control. After 2 days, the medium was aspirated. Cells were washed with cold PBS twice, and then stained with PI and Annexin V according to the manufacturer's instruction (Dead Cell Apoptosis Kit with Annexin V Alexa Fluor ${ }^{\mathrm{TM}} 488$ \& Propidium Iodide, Thermo Fisher), and analyzed immediately by flow cytometry (BD FACSCanto II Analyzer).

\section{Acridine orange (AO) assay}

Cells were treated with DMSO or compound 2 for $1 \mathrm{~h}$ prior to treatment with a $2 \mu \mathrm{g} / \mathrm{mL}$ Acridine Orange solution for $20 \min \left(37^{\circ} \mathrm{C}, 5 \% \mathrm{CO}_{2}\right)$, then washed with PBS. Images were obtained using an LSM 700 confocal microscope equipped with an argon laser (ex. $488 \mathrm{~nm}$ ). AO produces red fluorescence (emission peak at about $650 \mathrm{~nm}$ ) in the lysosomal compartments and green fluorescence (emission peak between 530 and $550 \mathrm{~nm}$ ) in the cytosolic and nuclear compartments. 


\subsection{Transport activities across plasma membranes}

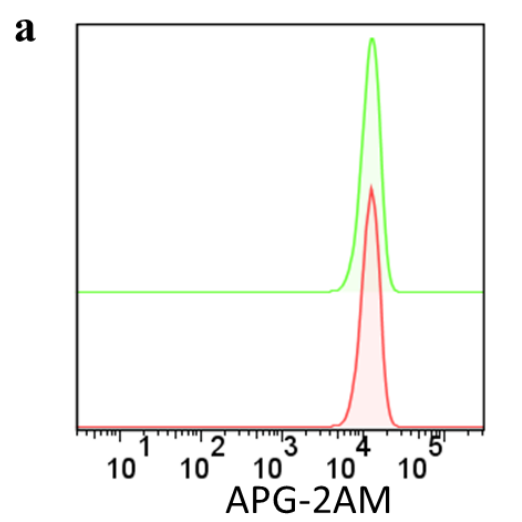

b

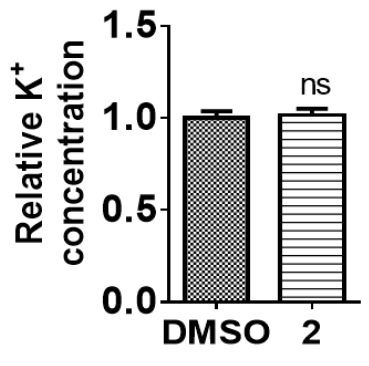

Figure S12. a, Representative result of cytosolic potassium concentration in HEYA8 cells measured by flow cytometry. Cells were treated with compound $\mathbf{2}$ at the concentration of 10 $\mu \mathrm{M}$ for $10 \mathrm{~min}$. The fluorescence of APG-2AM was analyzed with an excitation wavelength of $488 \mathrm{~nm}$ and an emission filter (530/30 nm). Three independent experiments were repeated. b, Quantification results of cytosolic potassium concentration in cells treated with DMSO or compound 2 (mean \pm s.e.m., $\mathrm{n}=3$ ).
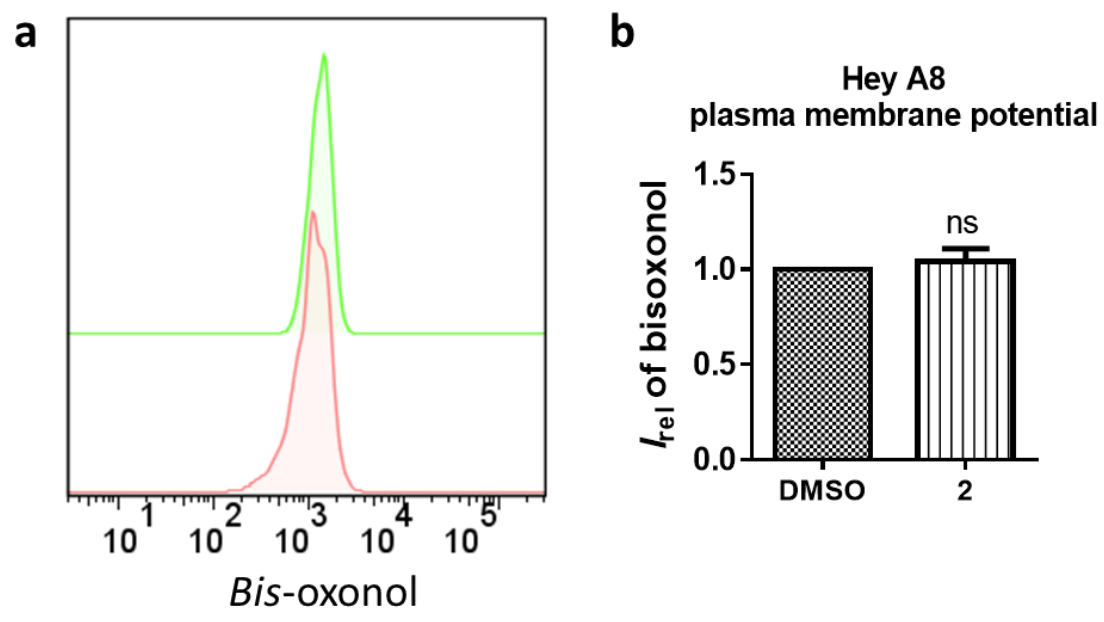

Figure S13. a, Representative result of HEYA8 cells plasma membrane potential measured by flow cytometry. Cells were treated with compound 2 at the concentration of $10 \mu \mathrm{M}$ for $30 \mathrm{~min}$. The fluorescence of bis-oxonol was analyzed with an excitation wavelength of $488 \mathrm{~nm}$ and an emission filter (530/30 nm). Three independent experiments were repeated. b, Quantification results of plasma membrane potential in HEYA8 cells treated with DMSO or compound 2 (mean \pm s.e.m., $n=3$ ). 
3.4 Transport activities across the mitochondria inner membranes

a

HeLa cells

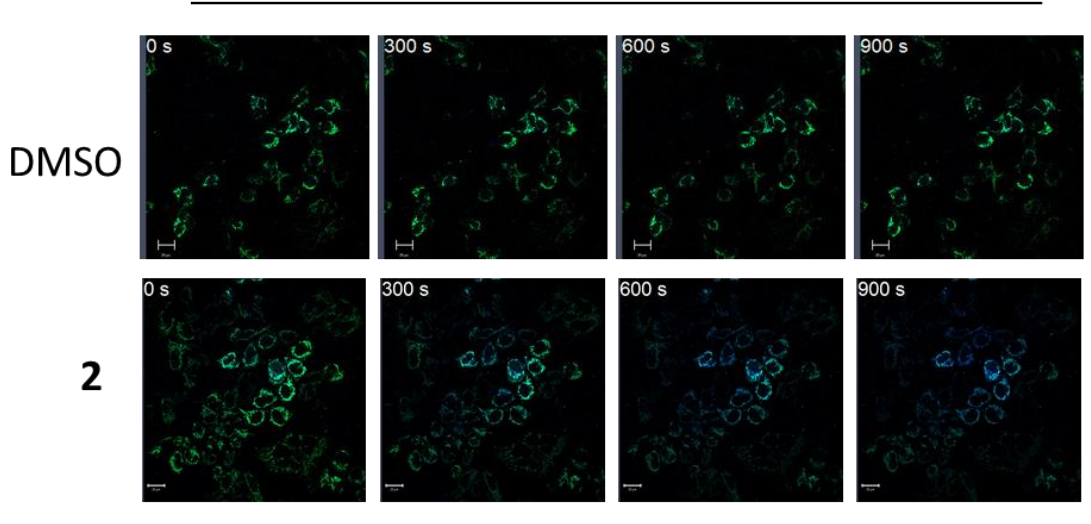

b

SKOV3 cells
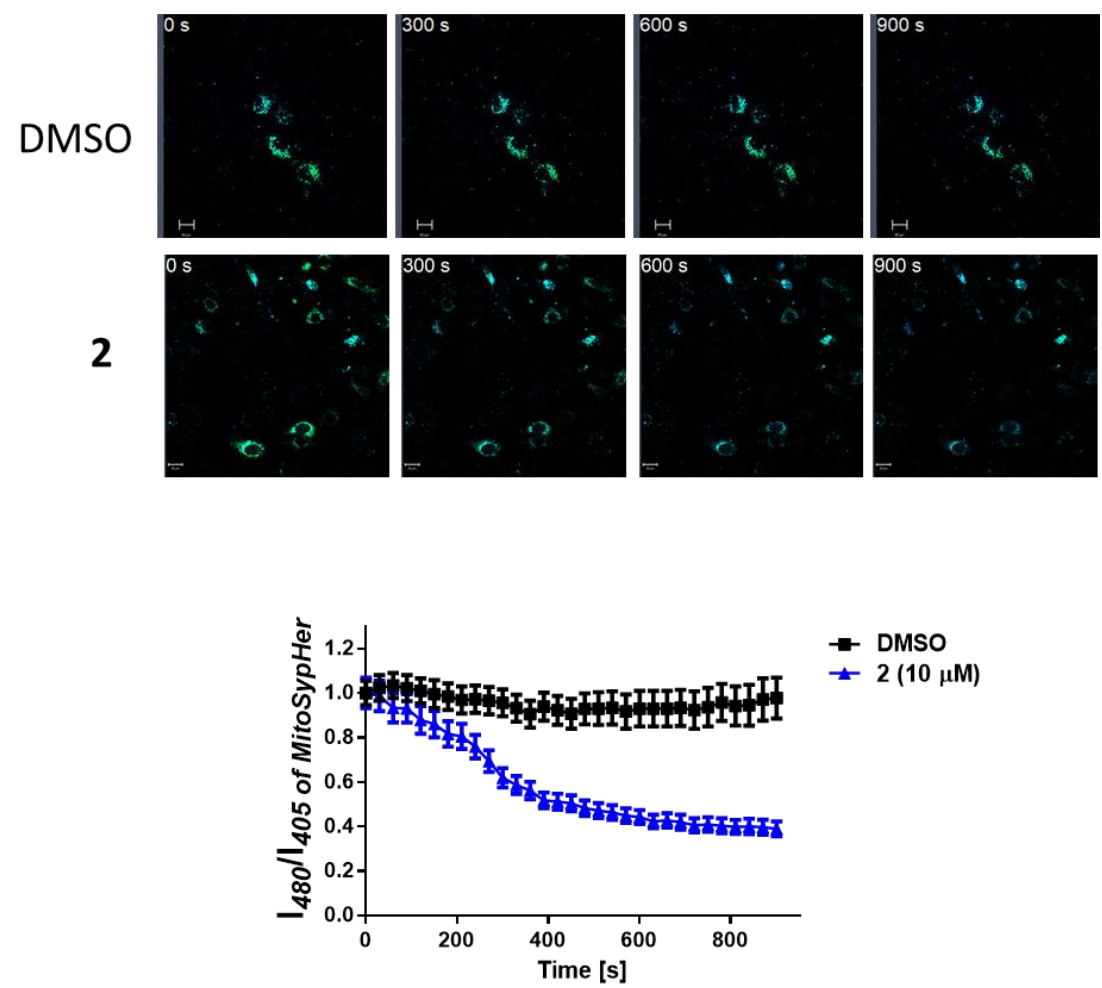

Figure S14. a, Fluorescence confocal images of Mito-SypHer showing the mitochondrial matrix pH levels in HeLa cells cells after treated with compound $2(10 \mu \mathrm{M})$ for $10 \mathrm{~min}$. b, Fluorescence confocal images and quantification results of Mito-SypHer showing the mitochondrial matrix $\mathrm{pH}$ levels in SKOV3 cells after treated with compound $2(10 \mu \mathrm{M})$ for 10 min. of matrix $\mathrm{pH}$ (mean \pm s.e.m., $\mathrm{n}=20-30$ cells). Images were obtained from kinetics experiments. Scale bar: $20 \mu \mathrm{m}$. 


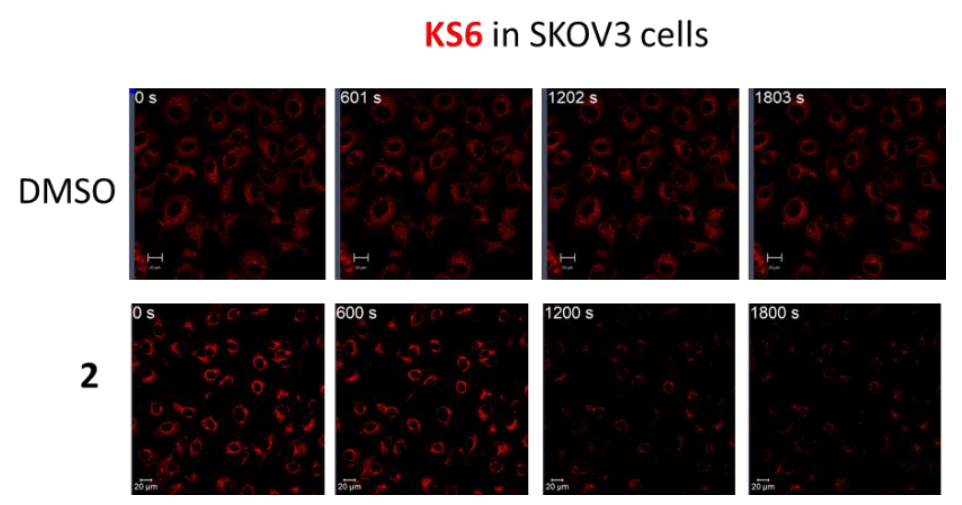

Figure S15. Fluorescence confocal images of KS6 showing the mitochondrial matrix $\mathrm{K}^{+}$ concentration in SKOV3 cells after treated with compound $2(10 \mu \mathrm{M})$ for $10 \mathrm{~min}$. Images were obtained from kinetics experiments. Scale bar: $20 \mu \mathrm{m}$.

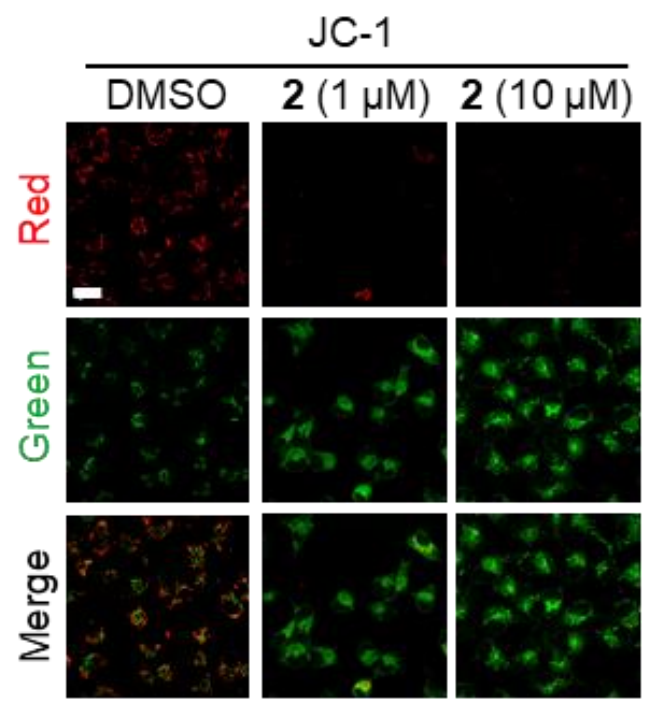

Figure S16. Fluorescence confocal images of JC-1 showing the mitochondrial inner membrane potential in HEYA8 cells after treated with compound $2(10 \mu \mathrm{M})$ for $10 \mathrm{~min}$. Images were obtained from kinetics experiments. Scale bar: $20 \mu \mathrm{m}$. 


\subsection{Mitochondrial superoxide production}

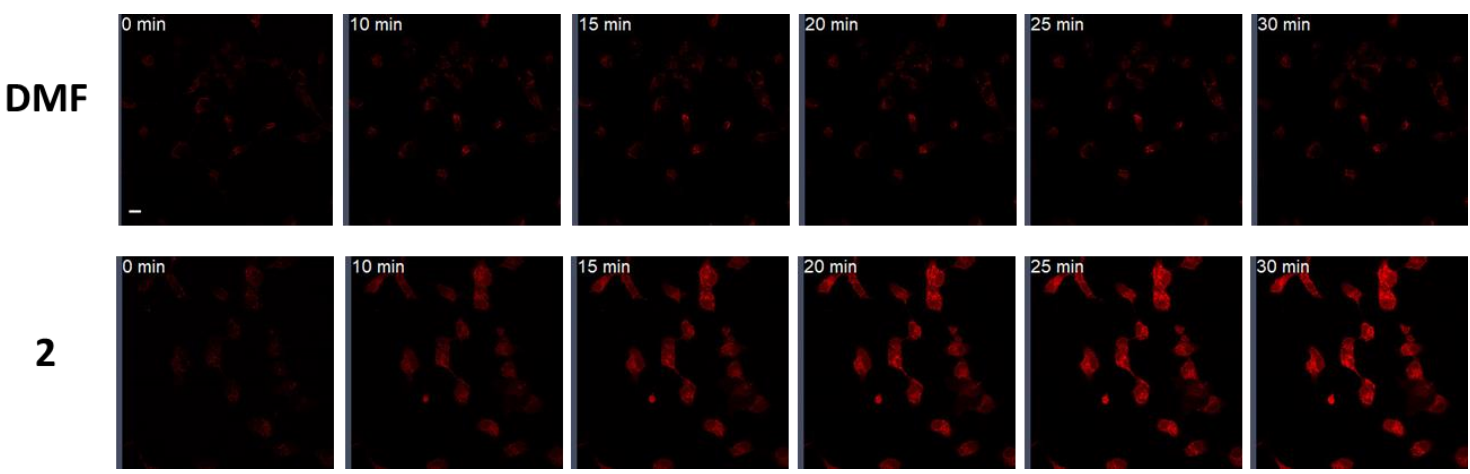

Figure S17. Fluorescence confocal images of HKSOX-2m probe showing the mitochondria superoxide production of HEYA8 cells after treatment with $0.1 \%$ DMF or compound $2(5 \mu \mathrm{M})$ for $30 \mathrm{~min}$. Scale bar: $20 \mu \mathrm{m}$.

\subsection{Characteristics of mitochondria in cancer stem cells}

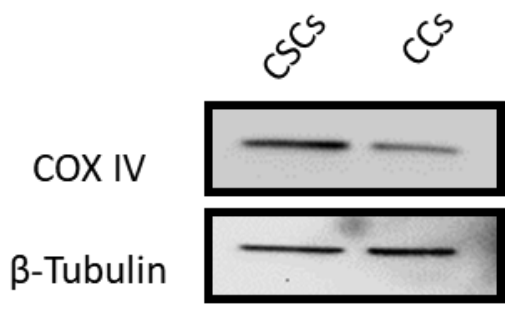

Figure S18. Immunoblotting of COX IV as a protein marker for mitochondria. $\beta$-Tubulin was used as the loading control. The upregulated COX IV suggested the higher mitochondrial mass of CSCs than adherent cancer cells (CCs). 
a

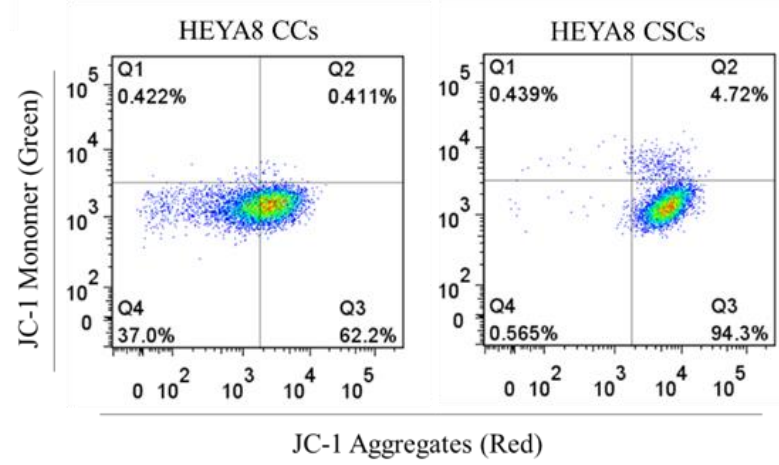

b

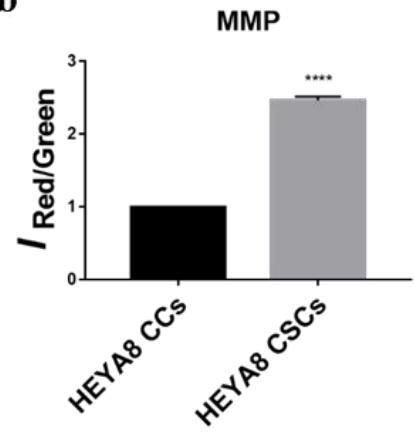

Figure S19. a, CSCs and adherent cancer cells (CCs) were stained with mitochondria membrane potential probe JC-1 and analyzed by FACS. b, Quantitative results from a (mean \pm s.e.m., $\mathrm{n}=3$, $* * * * \mathrm{p}<0.0001$. The higher ratio of red/green fluorescence indicated the hyperpolarized mitochondrial membrane potential of CSCs.

3.7 Effects on the mitochondrial membrane potential of CSCs and adherent cancer cells

a
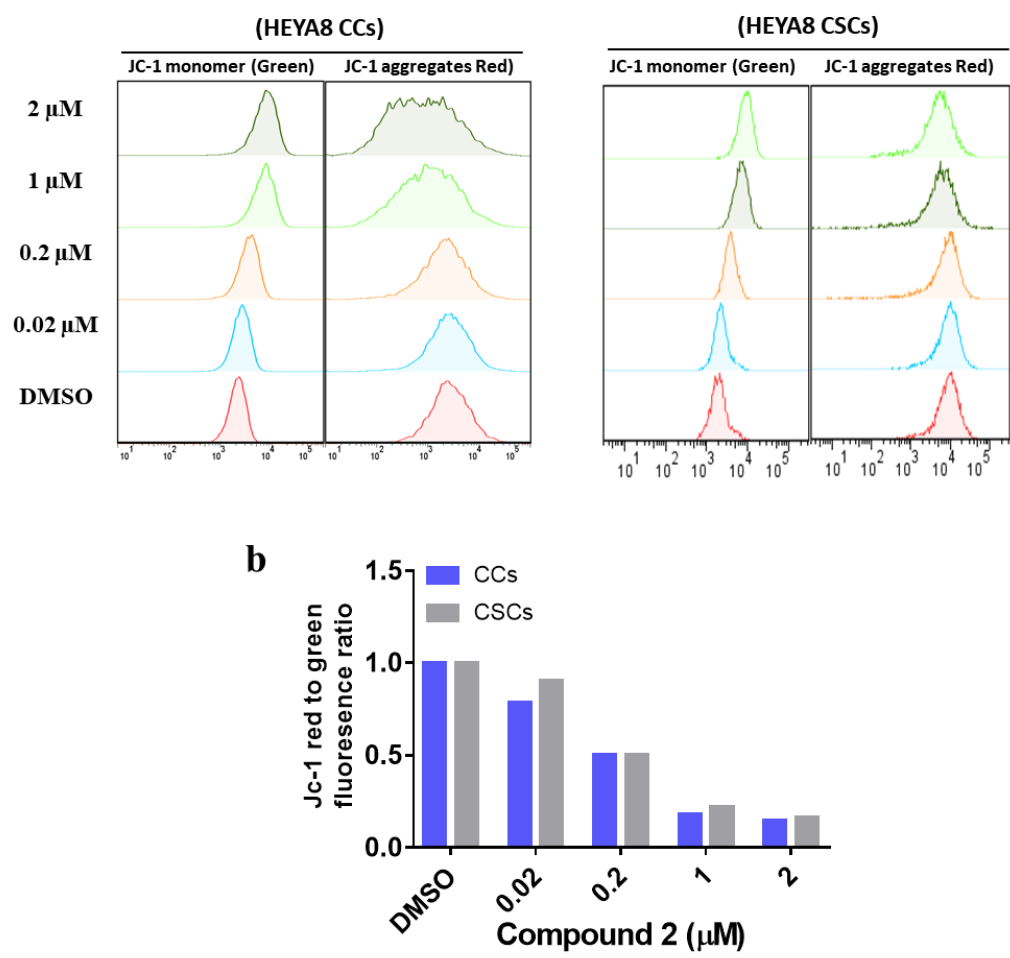

Figure S20. a, FACS analysis of JC-1 probe in HEYA8 adherent cancer cells and CSCs treated with DMSO or compound 2 at the indicated concentration for $10 \mathrm{~min}$. b, Quantitative results from a to show the effects of compound $\mathbf{2}$ on the mitochondrial membrane potential of adherent cancer cells and CSCs. 


\subsection{Cytotoxicity of cation transporters}
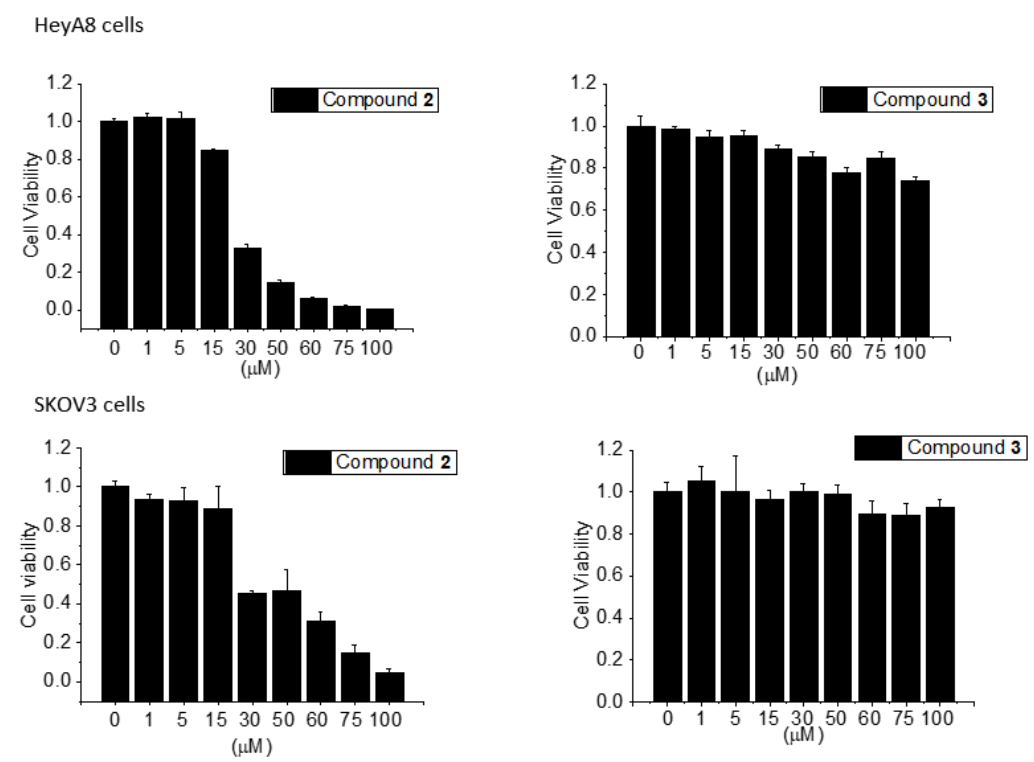

NIH3T3 cells
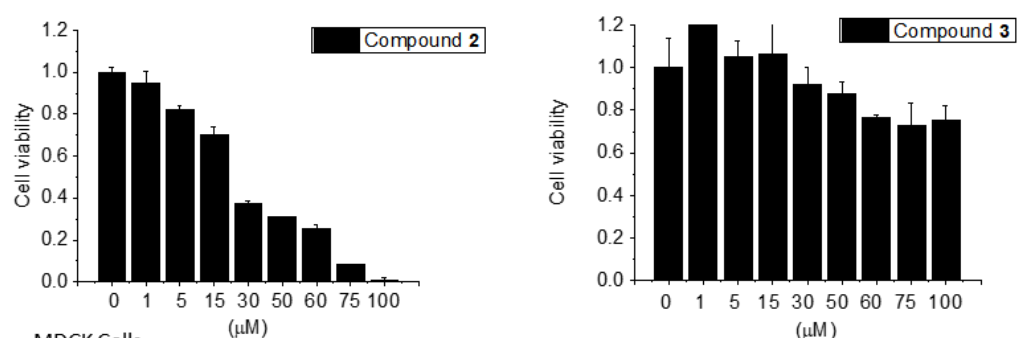

MDCK Cells

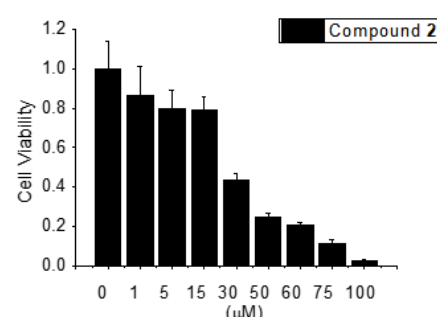

$(\mu \mathrm{M})$

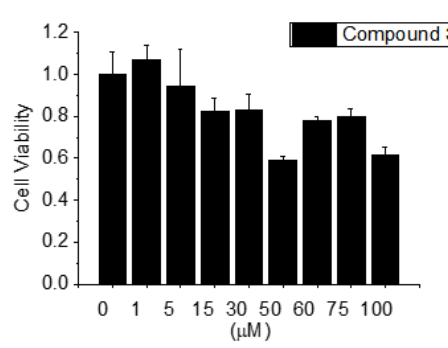

Compound 2
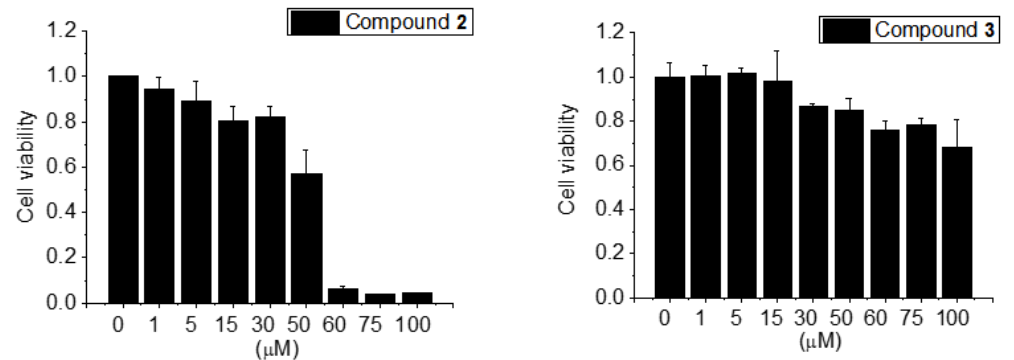

Figure S21. Representative results of cell viability after treatment with compound $\mathbf{2}$ or $\mathbf{3}$ for $48 \mathrm{~h}$. Values are reported as means of viable cells normalized with respect to untreated cells (mean \pm s.e.m., $n=3$ ). 


\subsection{ABC transporter expression}

The expression levels of $\mathrm{ABC}$ drug transporters in ovarian cancer HEYA8 adherent cancer cells and CSCs were investigated by immunoblotting. CSCs have expressed significantly higher amounts of ABCB1 and ABCG2 than that of HEYA8 adherent cancer cells.

\section{CCs CSCs}

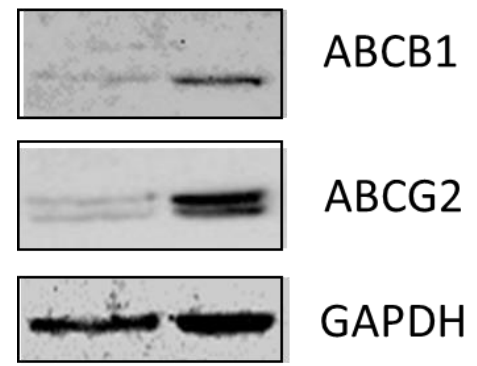

Figure S22. Immunoblots showing the levels ABCB1, ABCG2 and GAPDH (internal loading control) in HEYA8 cancer cells and CSCs.

\subsection{In vivo anti-tumor effect of compound 2}

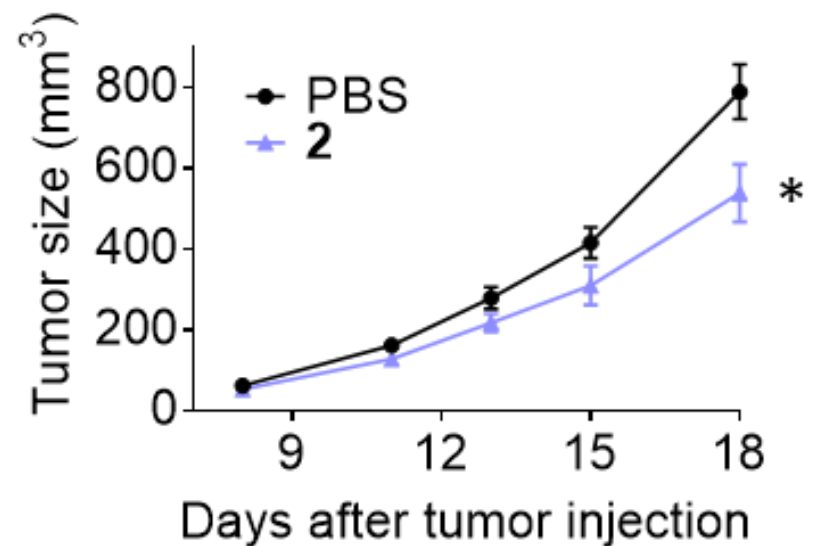

Figure S23. HEYA8 tumor-growth curves of mice treated with compound $2(5 \mathrm{mg} / \mathrm{kg}$ three days a week) or PBS buffer (mean \pm s.e.m., $n=5$ mice per group, ${ }^{*} p<0.05$ ). 


\section{References}

1. Yang, D.; Li, B.; Ng, F.-F.; Yan, Y.-L.; Qu, J.; Wu, Y.-D., Synthesis and Characterization of Chiral N-O Turns Induced by a -Aminoxy Acids. J. Org. Chem. 2001, 66 (22), 7303-7312.

2. Patterson, G. S., A Simplified Method for Finding the pKa of an Acid-Base Indicator by Spectrophotometry. J. Chem. Educ. 1999, 76 (3), 395.

3. Riddell, F. G.; Arumugam, S.; Brophy, P. J.; Cox, B. G.; Payne, M. C. H.; Southon, T. E., The nigericin-mediated transport of sodium and potassium ions through phospholipid bilayers studied by sodium-23 and potassium-39 NMR spectroscopy. J. Am. Chem. Soc. 1988, 110 (3), 734-738.

4. Kemmer, G.; Keller, S., Nonlinear least-squares data fitting in Excel spreadsheets. Nat. Protoc. 2010, 5 (2), 267-81.

5. Zeng, L. Z.; Zhang, H.; Wang, T.; Li, T., Enhancing K(+) transport activity and selectivity of synthetic $\mathrm{K}(+)$ channels via electron-donating effects. Chem. Commun. 2020, 56 (8), 1211-1214.

6. Ren, C.; Shen, J.; Zeng, H., Combinatorial Evolution of Fast-Conducting Highly Selective K+Channels via Modularly Tunable Directional Assembly of Crown Ethers. J. Am. Chem. Soc. 2017, 139 (36), 12338-12341.

7. Zhang, S.; Balch, C.; Chan, M. W.; Lai, H. C.; Matei, D.; Schilder, J. M.; Yan, P. S.; Huang, T. H.; Nephew, K. P., Identification and characterization of ovarian cancer-initiating cells from primary human tumors. Cancer Res. 2008, 68 (11), 4311-20.

8. Chau, W. K.; Ip, C. K.; Mak, A. S. C.; Lai, H. C.; Wong, A. S. T., c-Kit mediates chemoresistance and tumor-initiating capacity of ovarian cancer cells through activation of Wnt/ $\beta$-catenin - ATPbinding cassette G2 signaling. Oncogene 2012, 32, 2767. 


\section{Appendix}
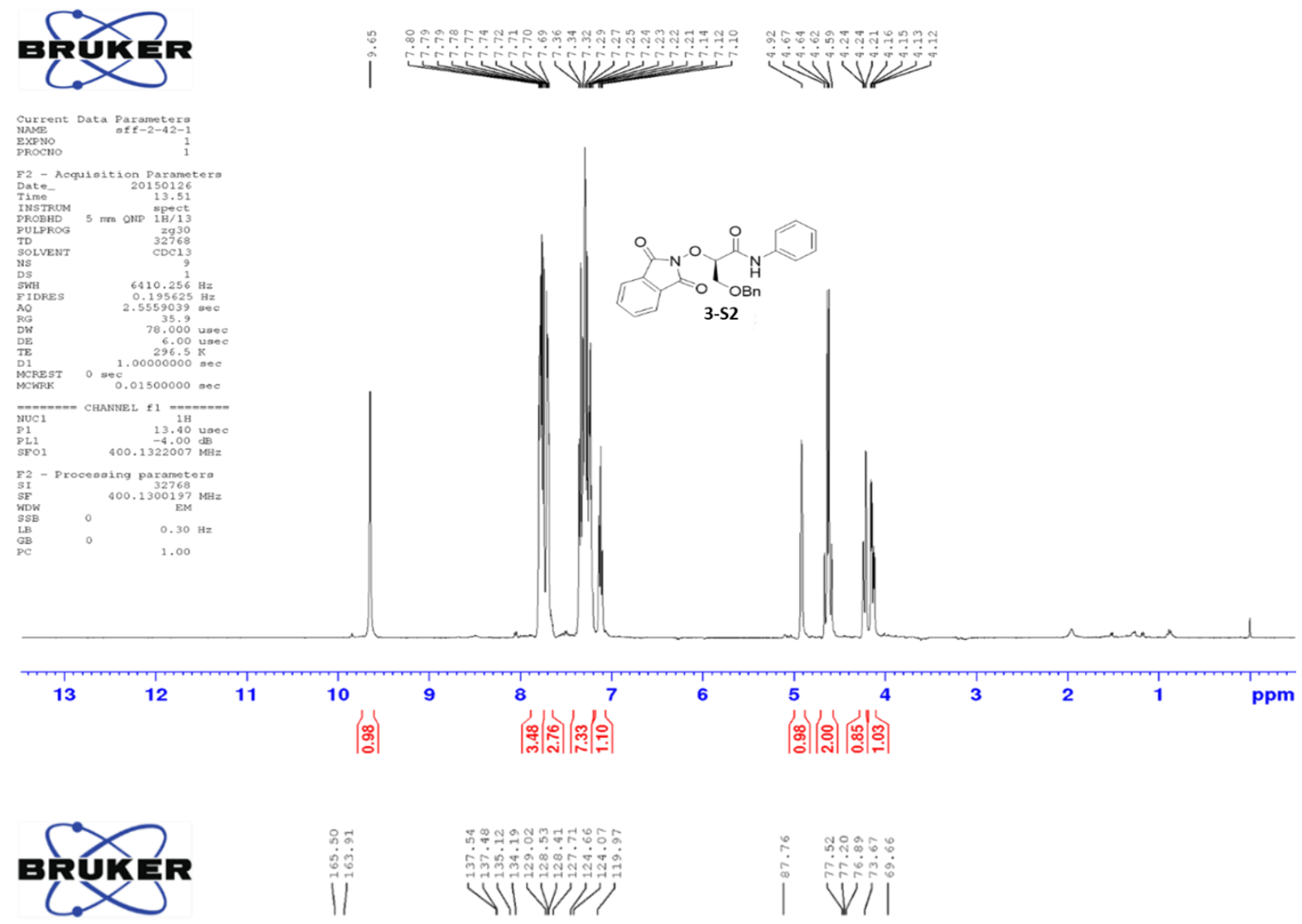

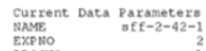

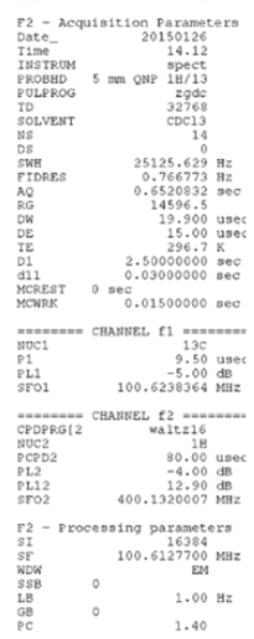

$\begin{array}{llllllllllllllllllllll}210 & 200 & 190 & 180 & 170 & 160 & 150 & 140 & 130 & 120 & 110 & 100 & 90 & 80 & 70 & 60 & 50 & 40 & 30 & 20 & \mathrm{ppm}\end{array}$ 

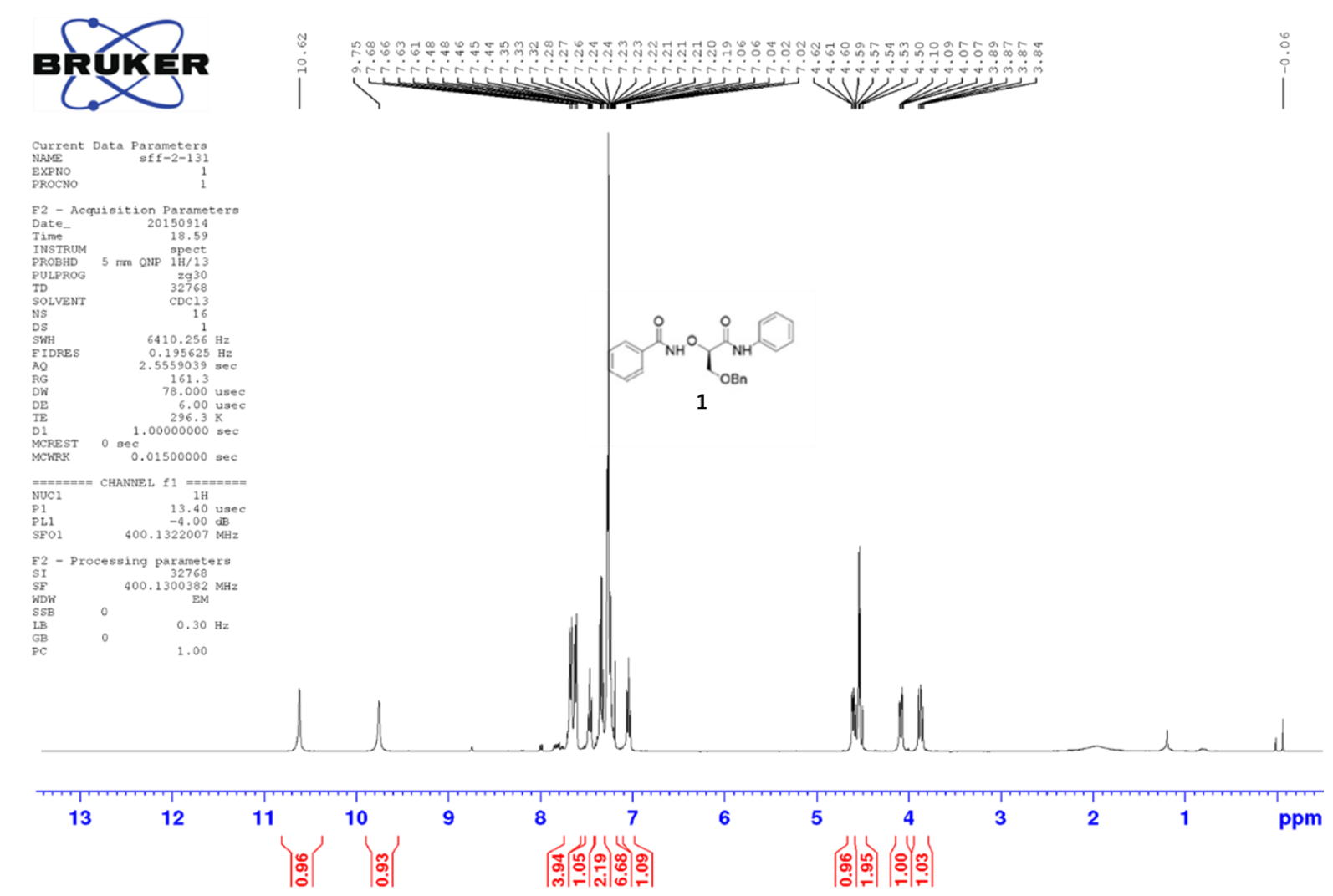

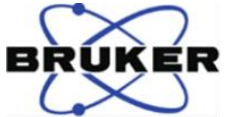

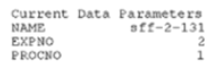
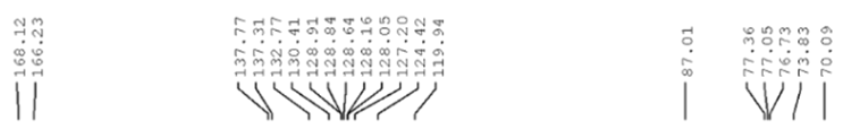

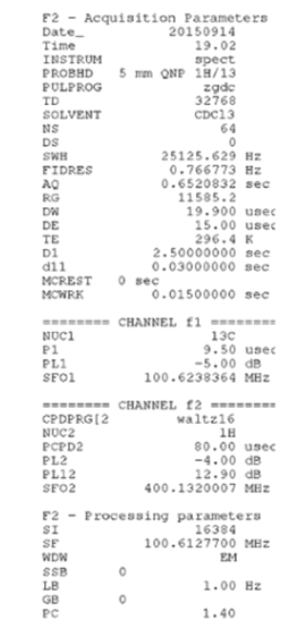

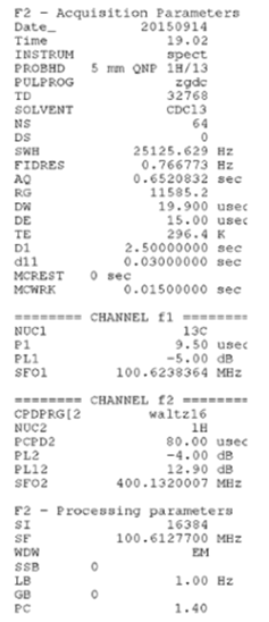




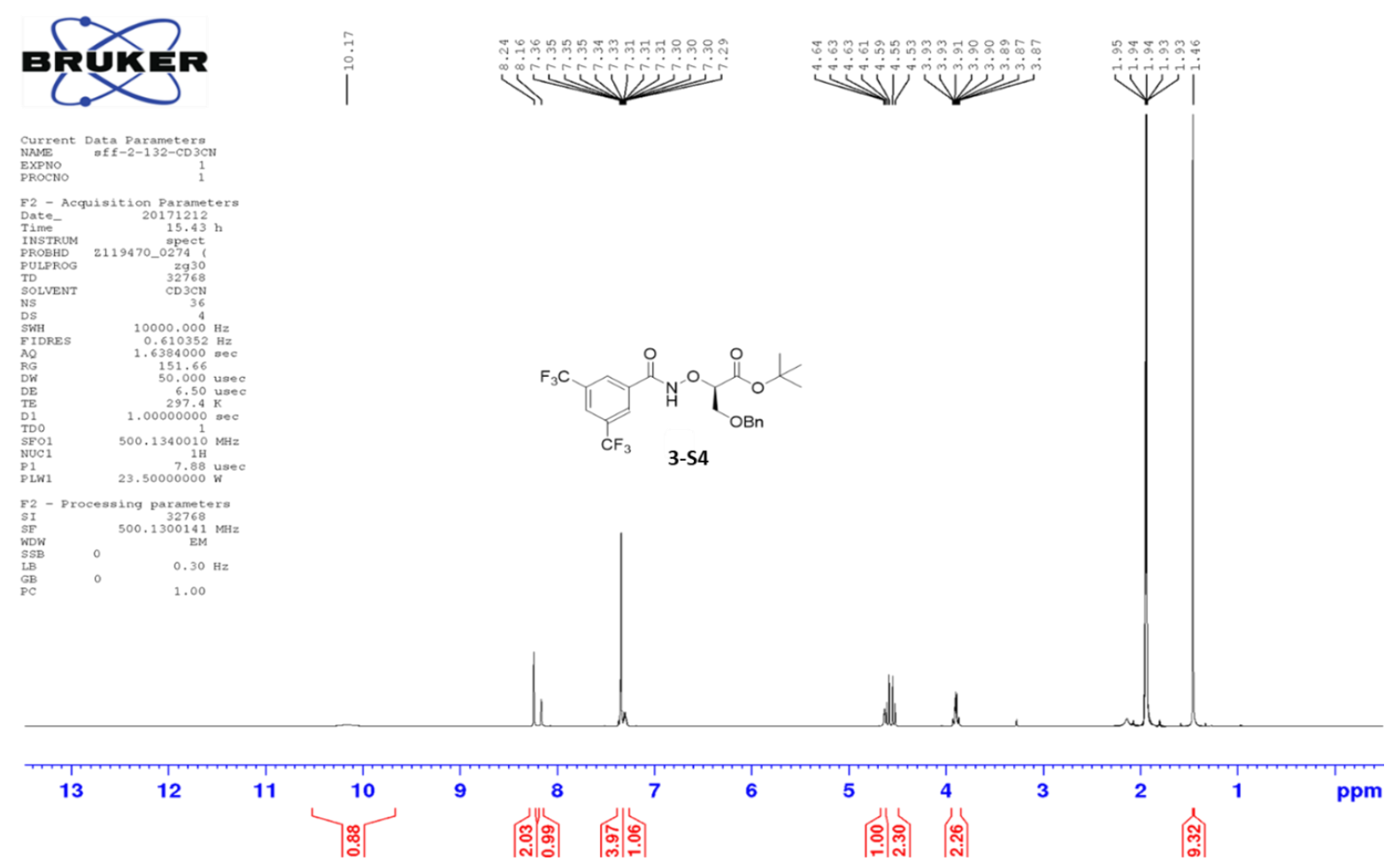

\section{BRUKER}

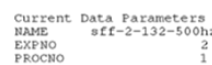

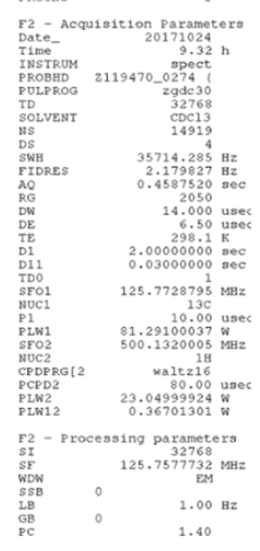

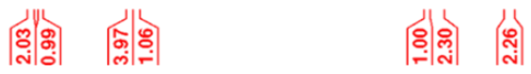

隹|

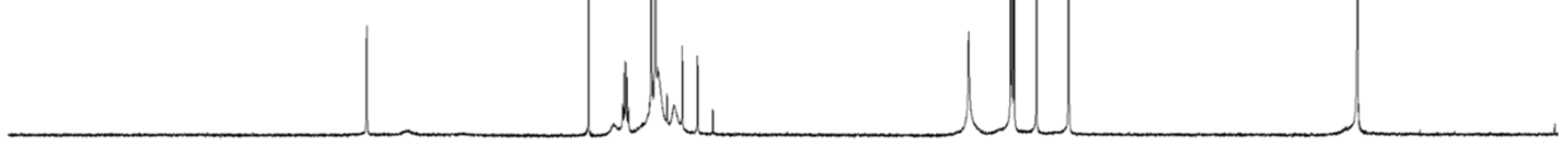

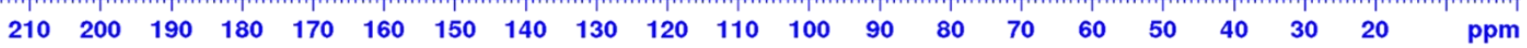




\section{BRYKER}

$\begin{array}{lr}\text { Current Data } & \text { Parameters } \\ \text { NAME } & \text { sff }-2-122 \\ \text { EPRNO } & 1 \\ \text { PROCNO } & 1\end{array}$

F2 - Acquisition Parameters
Date- 2015081
Time
Time

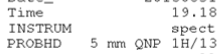

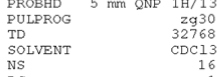

$\begin{array}{lr}\text { DS } & 1 \\ \text { SWH } & 6410.256 \mathrm{H} \\ \text { FIDRES } & 0.195625 \mathrm{H} \\ \text { AQ } & 2.55590399 \\ \text { AQ } & \end{array}$

$\begin{array}{lr}\text { AQ } & 2.5559039 \mathrm{sec} \\ \text { RG } & 181 \mathrm{e} \\ \text { DW } & 78.000 \text { usec } \\ \text { DE } & 6.00 \text { use } \\ \text { TE } & 298.0 \mathrm{~K} \\ \text { D1 } & 1.00000000 \mathrm{sec}\end{array}$

$\begin{array}{lll}\text { MCREST } & 1.00000000 \mathrm{sec} \\ \text { MCWRK } & 0.01500000 & 0.0\end{array}$

$======$ CHANNEL $\mathrm{f} 1======$
NUC1
$\mathrm{P} 1 \mathrm{H}$
$13.40 \mathrm{use}$

$\begin{array}{lr}\text { PL1 } & 13.40 \text { use } \\ \text { PEO1 } & -4.000 \mathrm{~dB} \\ \text { SEO } & 400.132007 \mathrm{MHz}\end{array}$

$\begin{array}{rr}\text { F2 } & \text { Processing parameters } \\ \text { SI } & 32768 \\ \mathrm{SF} & 400.130096 \mathrm{MHz}\end{array}$

$\begin{array}{lcc}\text { WF } & & 400.1300096 \\ \text { WDB } & 0 & \text { EM } \\ \text { SB } & 0 & 0.30 \mathrm{~Hz} \\ \text { LB } & 0 & \end{array}$

$\begin{array}{ll}\mathrm{GB} & 0 \\ \mathrm{PC} & 1.00\end{array}$

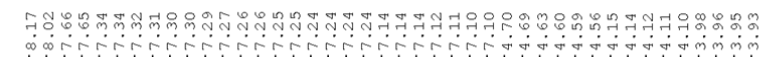

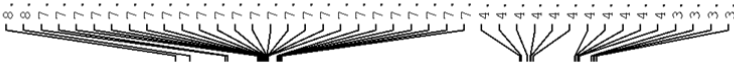
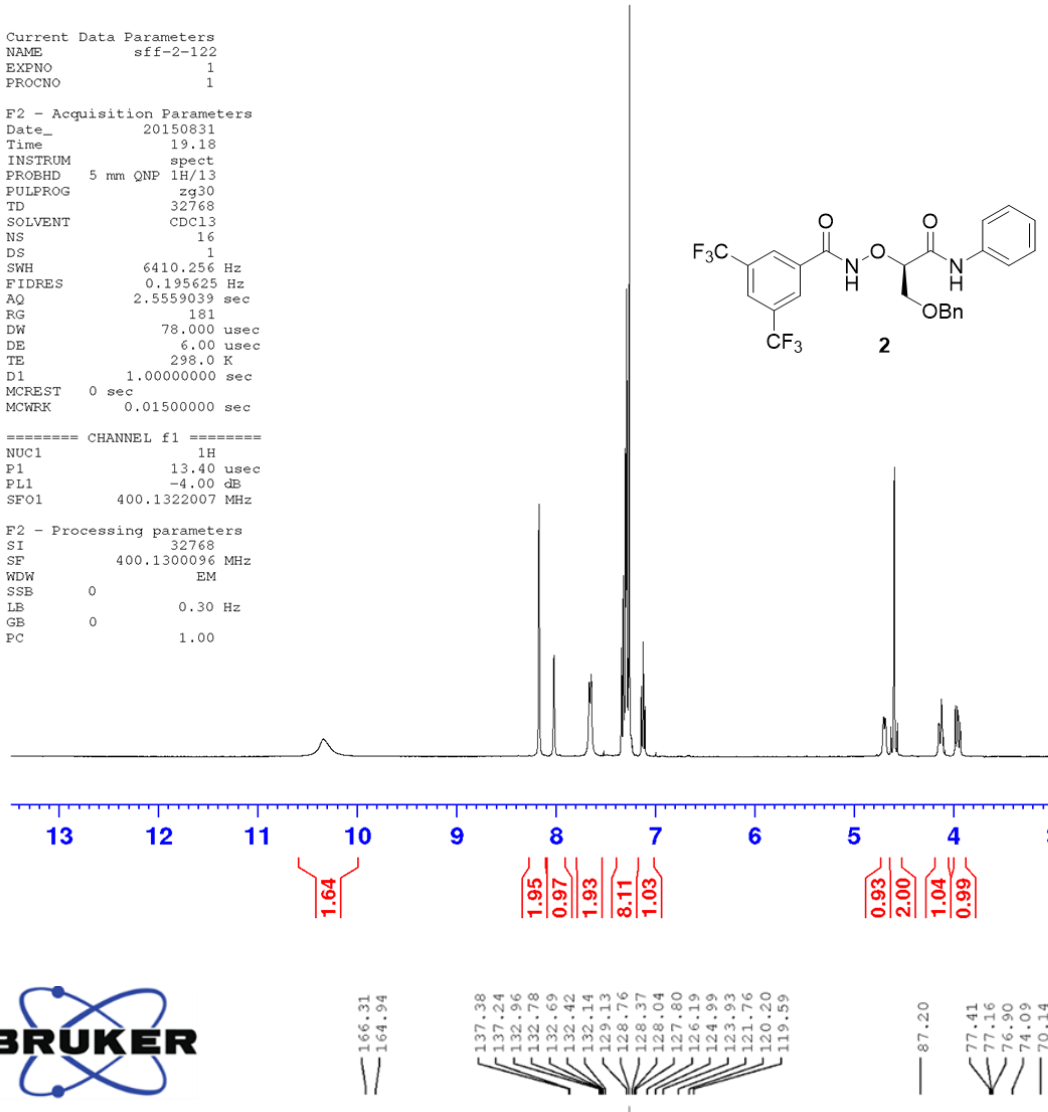

Current Data parameters
NAME
EXPNO
SIf-2-112-50

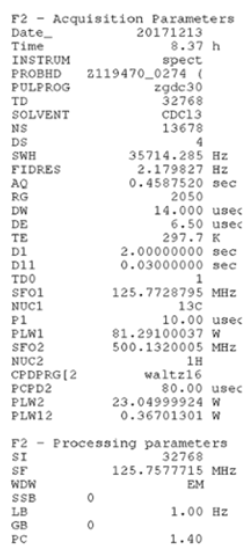

.

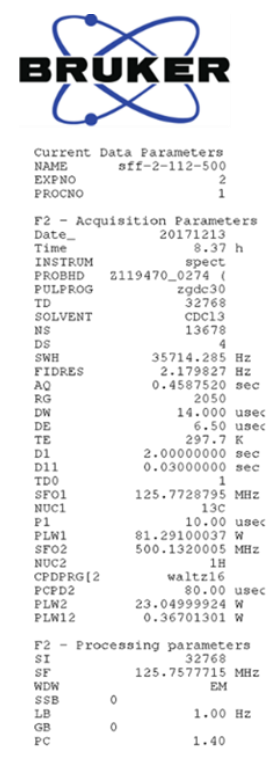

Wil

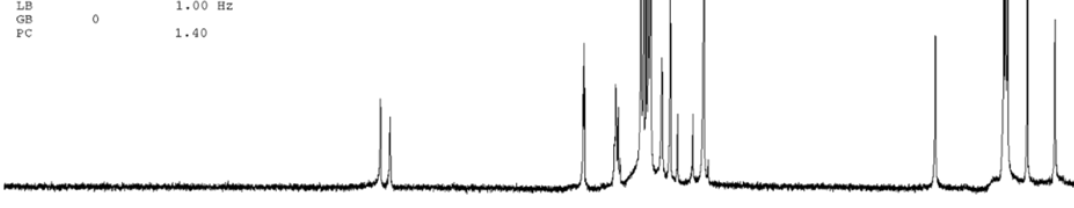

$\begin{array}{llllllllllllllllllllll}210 & 200 & 190 & 180 & 170 & 160 & 150 & 140 & 130 & 120 & 110 & 100 & 90 & 80 & 70 & 60 & 50 & 40 & 30 & 20 & \end{array}$ 


\section{BRUKER}

Current Data Parameters
NAME
EXPNO
sff $-2-122$
PROCNON
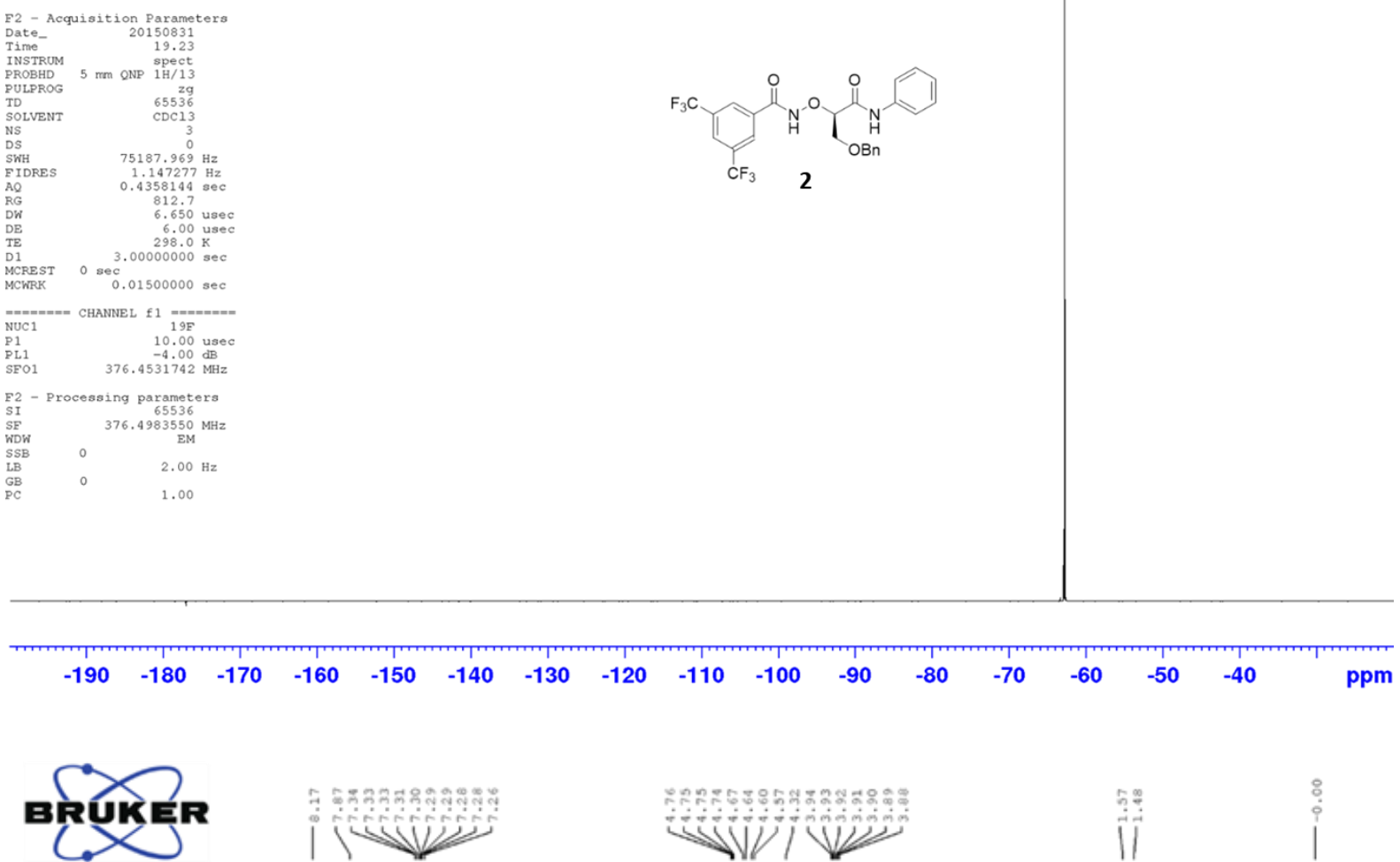

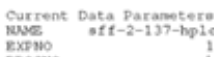
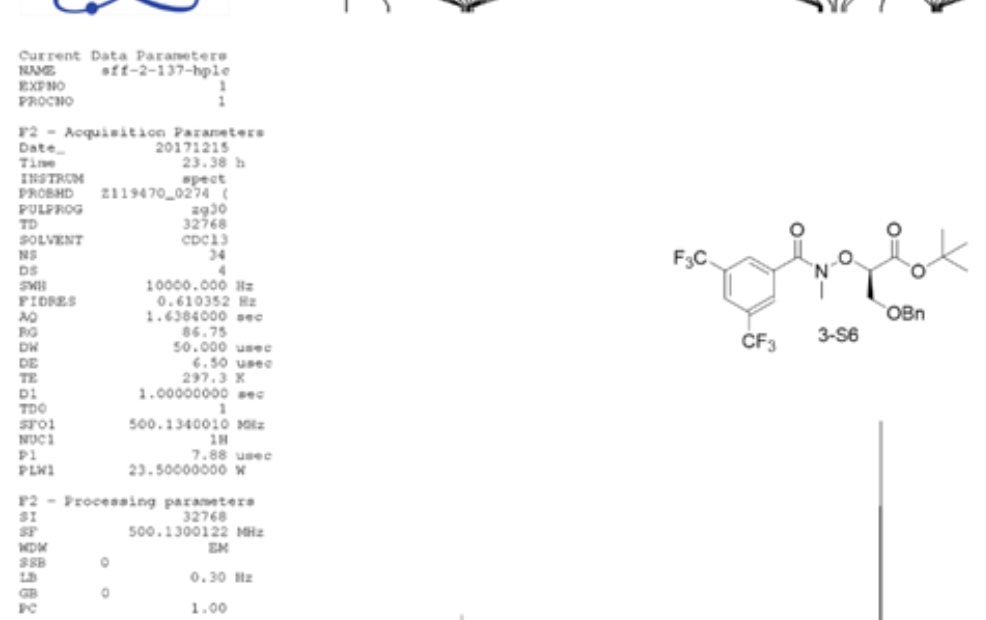

1,00
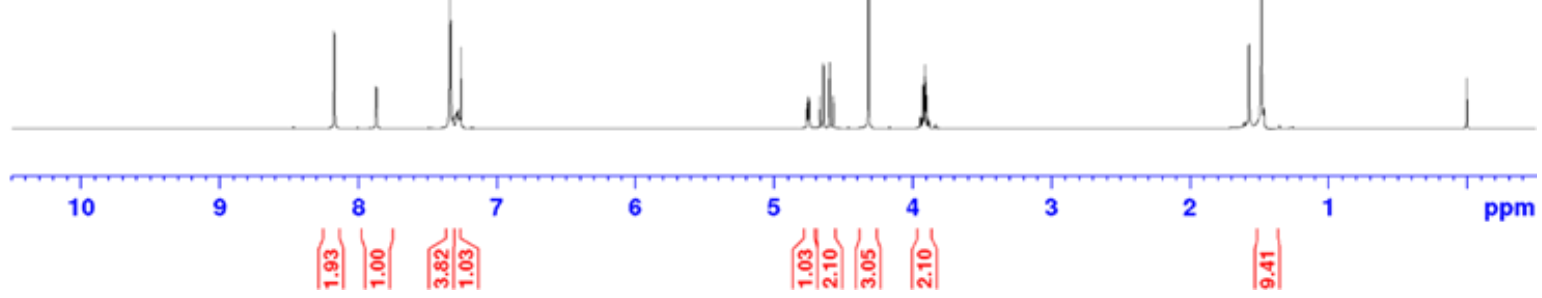


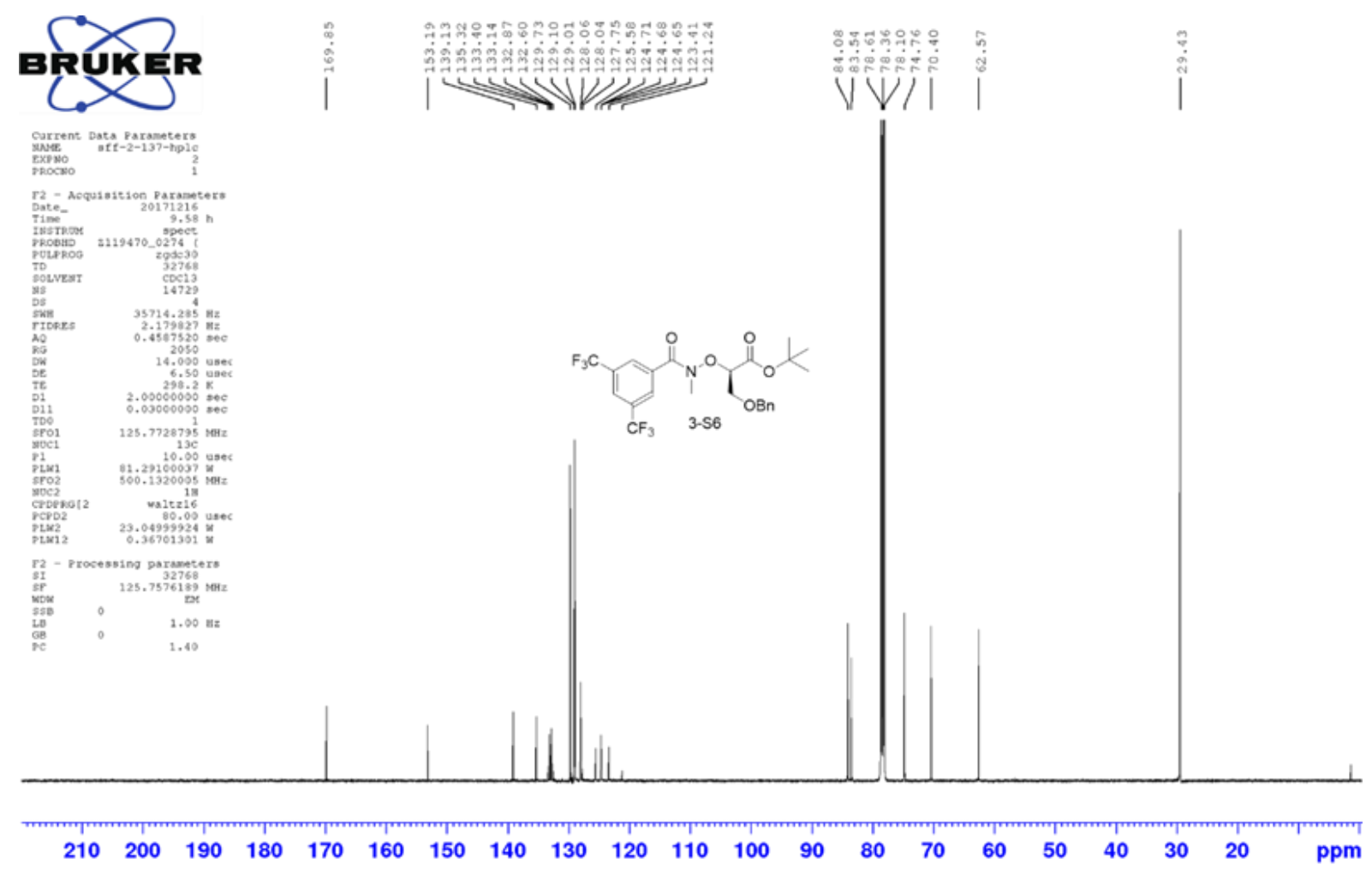

\section{BRUKER}

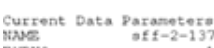

RRE
EXONO
PROCNO

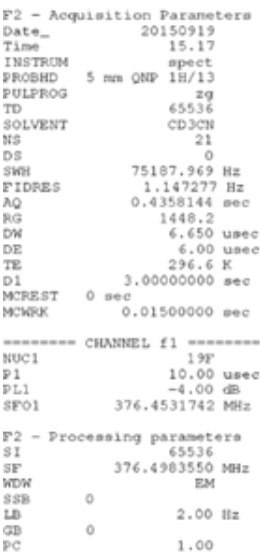

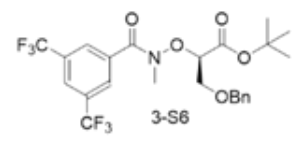

$-190-180$

$\begin{array}{lllllll}-170 & -160 & -150 & -140 & -130 & -120 & -110\end{array}$

$-90 \quad-80$

$\begin{array}{llll}-70 & -60 & -50 & -40\end{array}$

ppm 


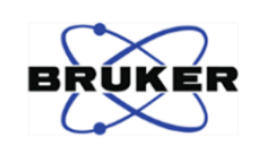

$\begin{array}{lr}\text { Current } & \text { Data Parameters } \\ \text { NAME } & \text { sff } \\ \text { EXPNO } & 1-2138-2 \\ \text { PROCNO } & 1\end{array}$

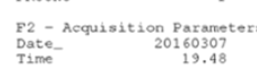

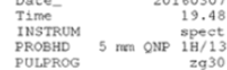

$\begin{array}{lr}\text { PULPROG } & 2930 \\ \text { TD } & 32768 \\ \text { SOLVENT } & \text { CD13 } \\ \text { NS } & 16 \\ \text { DS } & 1\end{array}$

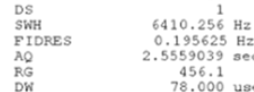

$\begin{array}{lr}\text { DW } & 78.000 \text { usec } \\ \text { DE } & 6.00 \text { usec } \\ \text { TE } & 296.33 \mathrm{~K} \\ \text { D1 } & 1.00000000 \mathrm{sec}\end{array}$

MCREST O sec 1.00000000 ses

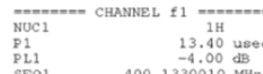

SFO1 $400.1330010 \mathrm{MHz}$

$\begin{array}{lcc}\text { F2 } & \text { - Procesaing parameters } \\ \text { SI } & \text { 32768 } \\ \text { SE } & 400.1300102 \mathrm{MHz} \\ \text { WDW } & 0 & \text { EM } \\ \text { SSB } & 0 & 0.30 \mathrm{~Hz} \\ \text { LB } & 0 & 1.00 \\ \text { GB } & 0 & \end{array}$
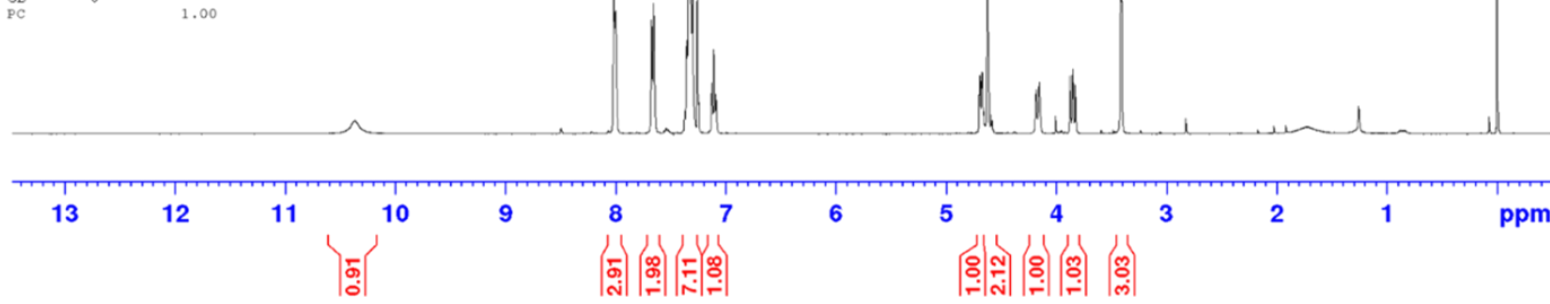

\section{BRUKER}

Current Data parametern
MAME
EXPMO
PROC
PROCDO

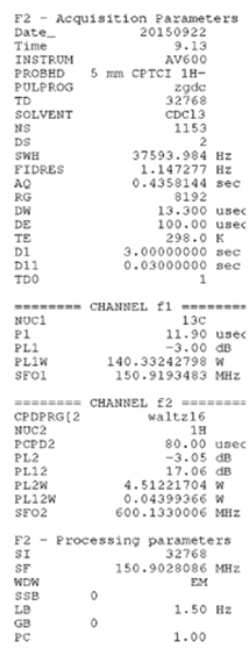

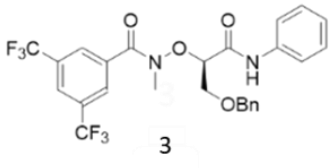

స్తి|

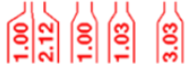

pm 


\section{करिखिR}

Current Data Parametera

NAME
EXPNO
PROCNO

$\begin{array}{lc}\text { E2- } 2 \text {-Acquisition Parameters } \\ \text { Date- } & 20150921 \\ \text { Time } & 15.19\end{array}$

$\begin{array}{ll}\text { Time } & 15.19 \\ \text { INSTRUM } & \text { spect } \\ \text { PROBHD } & \text { PROB }\end{array}$

$\begin{array}{lr}\text { PULPROG } & 29 \\ \text { TD } & 6556 \\ \text { SOLVENT } & C D 3 C N \\ \text { NS } & 3\end{array}$

$\begin{array}{ll}\text { DS } & 0 \\ \text { SWH } & 75187.969 \mathrm{~Hz} \\ \text { FIDDES } & 1.147277 \mathrm{~Hz} \\ \text { AO } & 0.4358144 \mathrm{sec}\end{array}$

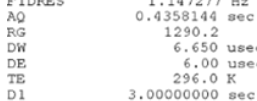

M1 $3.00000000 \mathrm{sec}$

MCWRK $0.01500000 \mathrm{sec}$

$\begin{array}{lr}\text { NUC1 } & 19 \mathrm{~F} \\ \text { P1 } & 10.00 \text { use } \\ \text { PL1 } & -4.00 \mathrm{~dB} \\ \text { SF01 } & 376.4531742 \mathrm{MHz}\end{array}$

$\begin{array}{lcc}\text { F2 } & \text { Processing parameters } \\ \text { SI } & \text { Proces } \\ \text { SE } & 376.4983550 \mathrm{MHz} \\ \text { SD } & & \text { EM } \\ \text { WDW } & 0 & 2.00 \mathrm{~Hz} \\ \text { SSB } & 0 & 2.00 \\ \text { LB } & 0 & 1.00 \\ \text { GB } & \end{array}$

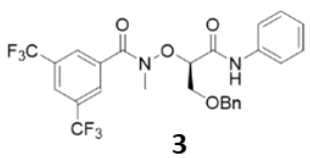

3

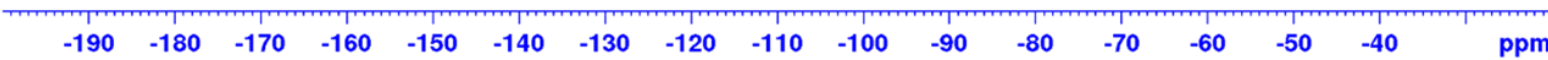

\section{BRUMER}

Current Data Parameters
MAME
EXPNO
PROCNO
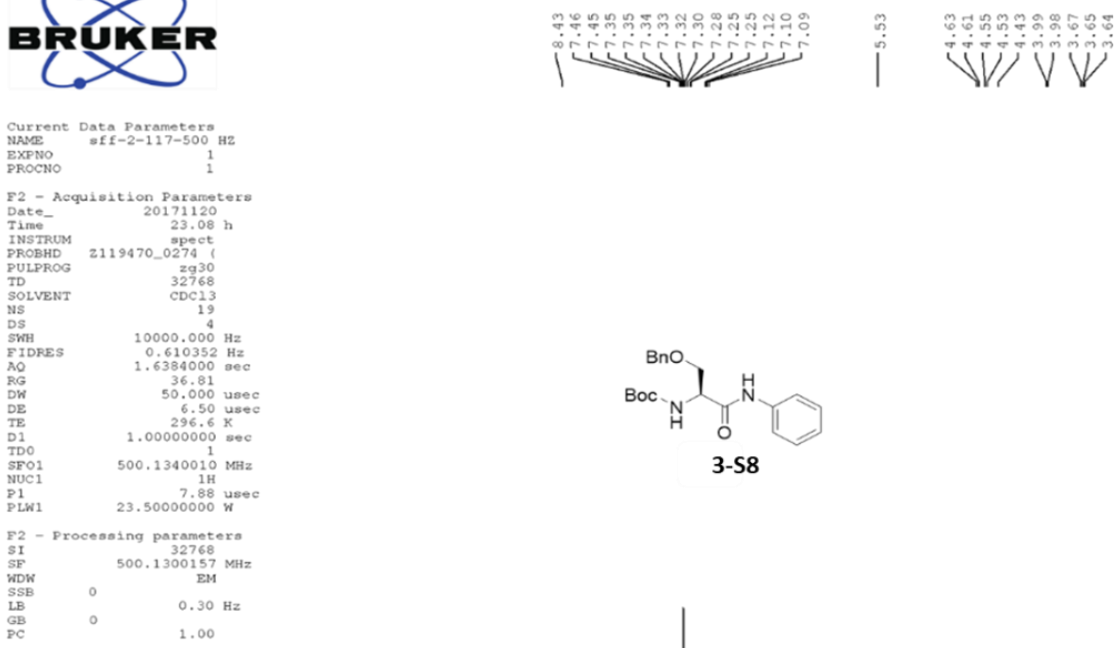

3-58

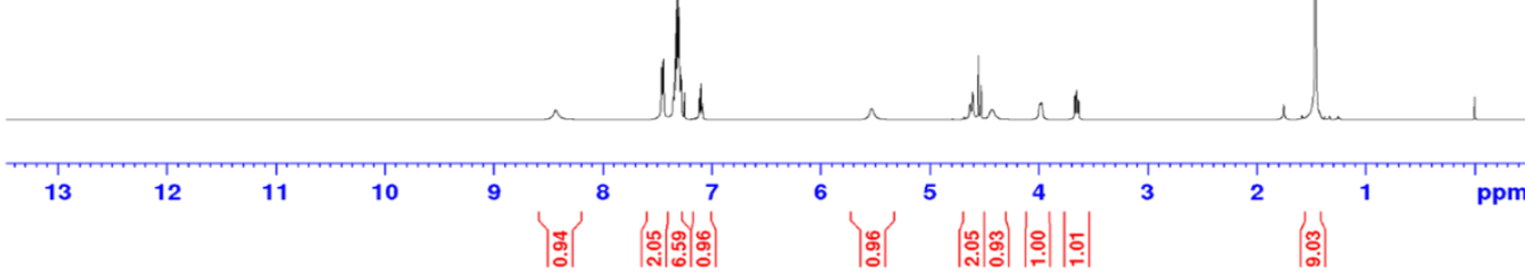



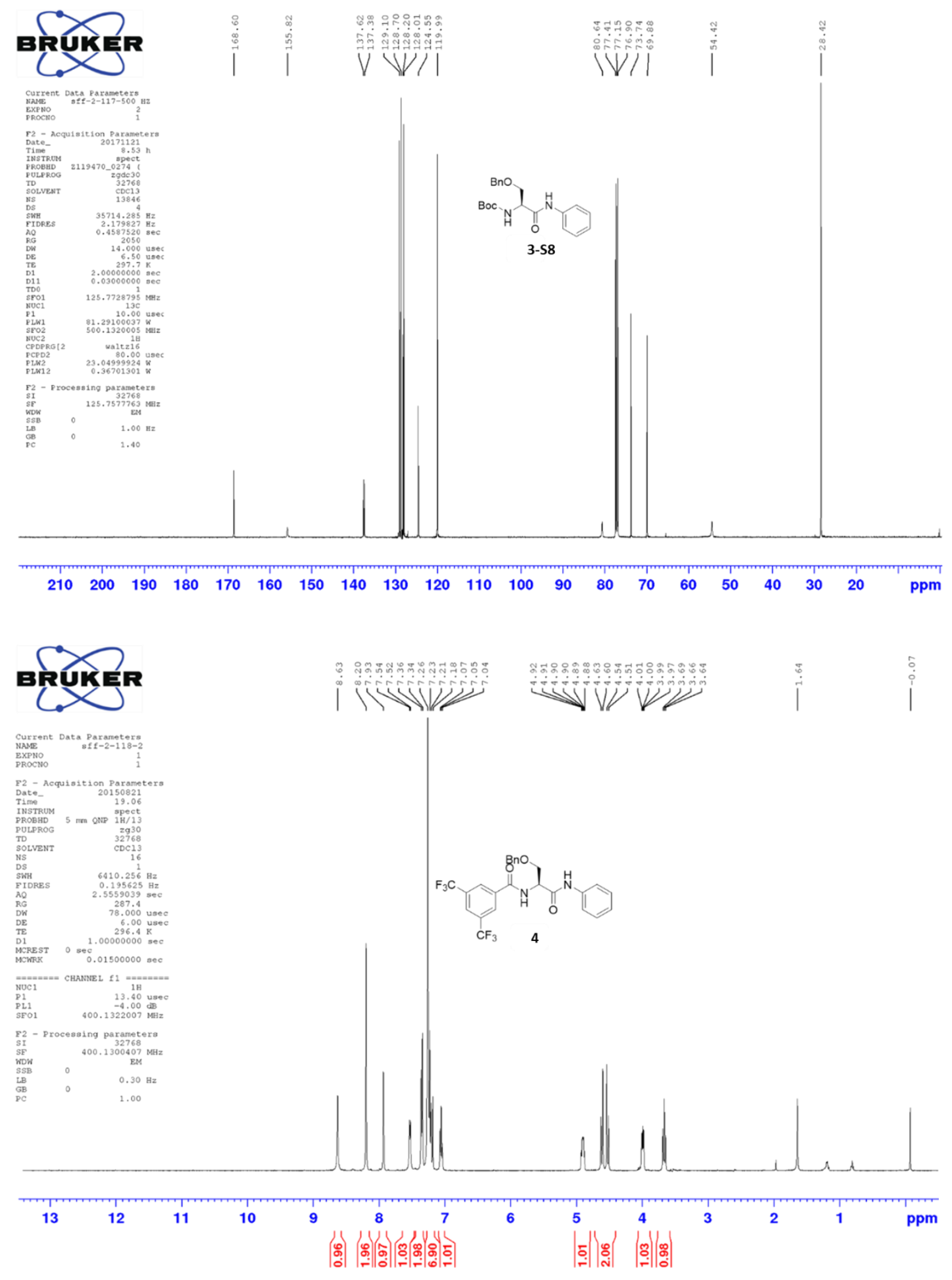

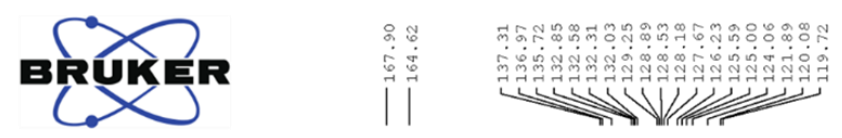

ฟîं

Current Data Parameters
NAME
EXPHO
$\mathrm{sff} f-2-118$
3

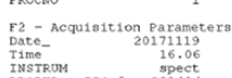

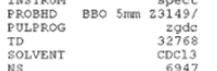

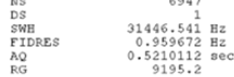

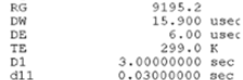

Mi1
MCREST
MCWRK

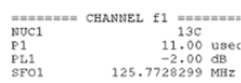

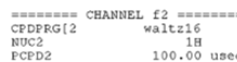

$\begin{array}{lr}\text { PL2 } & -6.00 \mathrm{~dB} \\ \text { PL12 } & 14.00 \mathrm{~dB} \\ \text { PLO2 } & 500.1312000 \mathrm{MBH}\end{array}$

$\begin{array}{ll}\mathrm{F} 2 & \text { - Processing parameters } \\ \text { S1 } & 32768 \\ \text { SF } & 125.7577720 \mathrm{MHz} \\ \text { WP } & \end{array}$

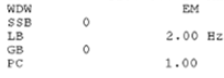

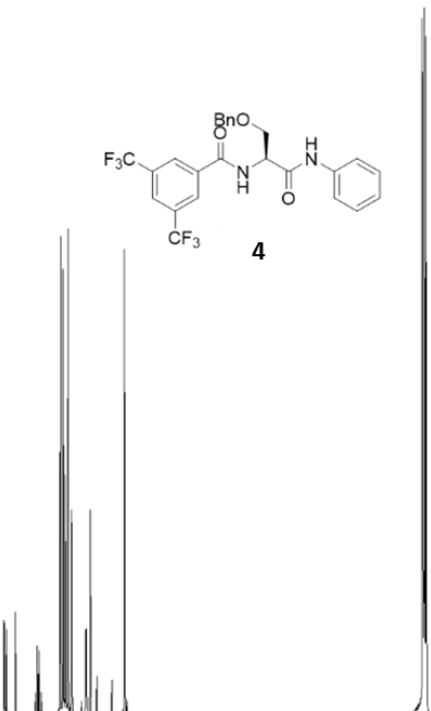

$\begin{array}{lllllllllllllllllllll}210 & 200 & 190 & 180 & 170 & 160 & 150 & 140 & 130 & 120 & 110 & 100 & 90 & 80 & 70 & 60 & 50 & 40 & 30 & 20 & \text { ppm }\end{array}$

\section{BRUKER}

Current Data Parameters
NMME
sf $f-2-118-2$

NNME
EXPNO
PROCNO
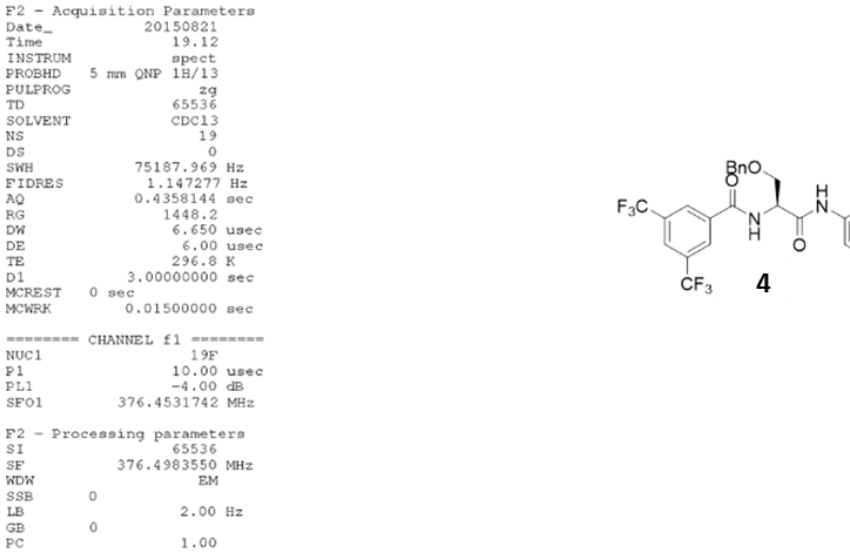

$-190$

$-180$

$-170-1$

$-150$

$-140$

$-130-120$

$-110-100$ 

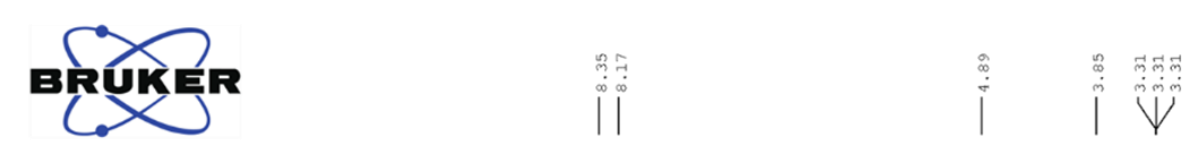

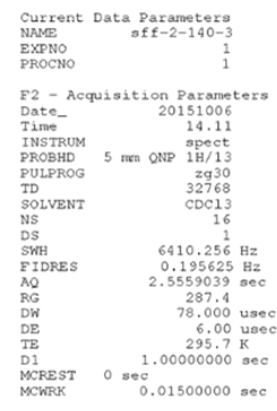

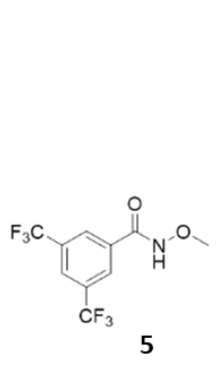

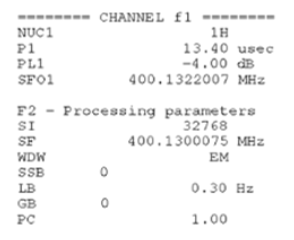

5

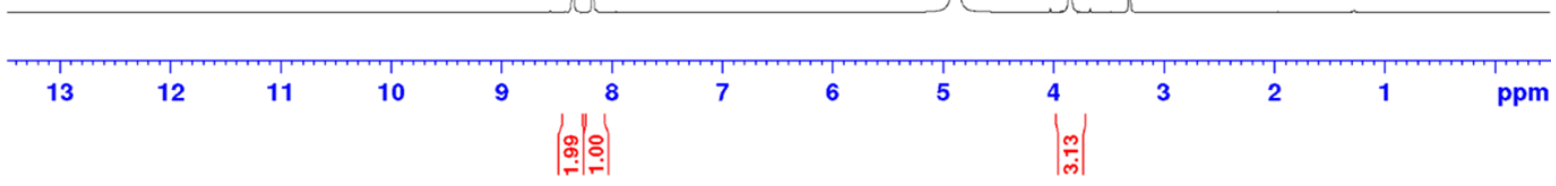

\section{BRUKER}

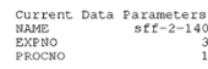

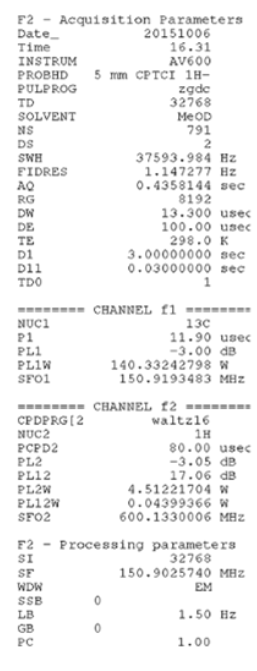

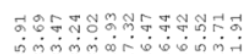

s.

W IVEII

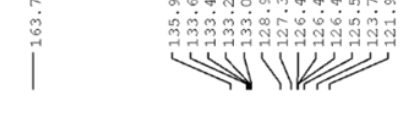

ن

(n) 

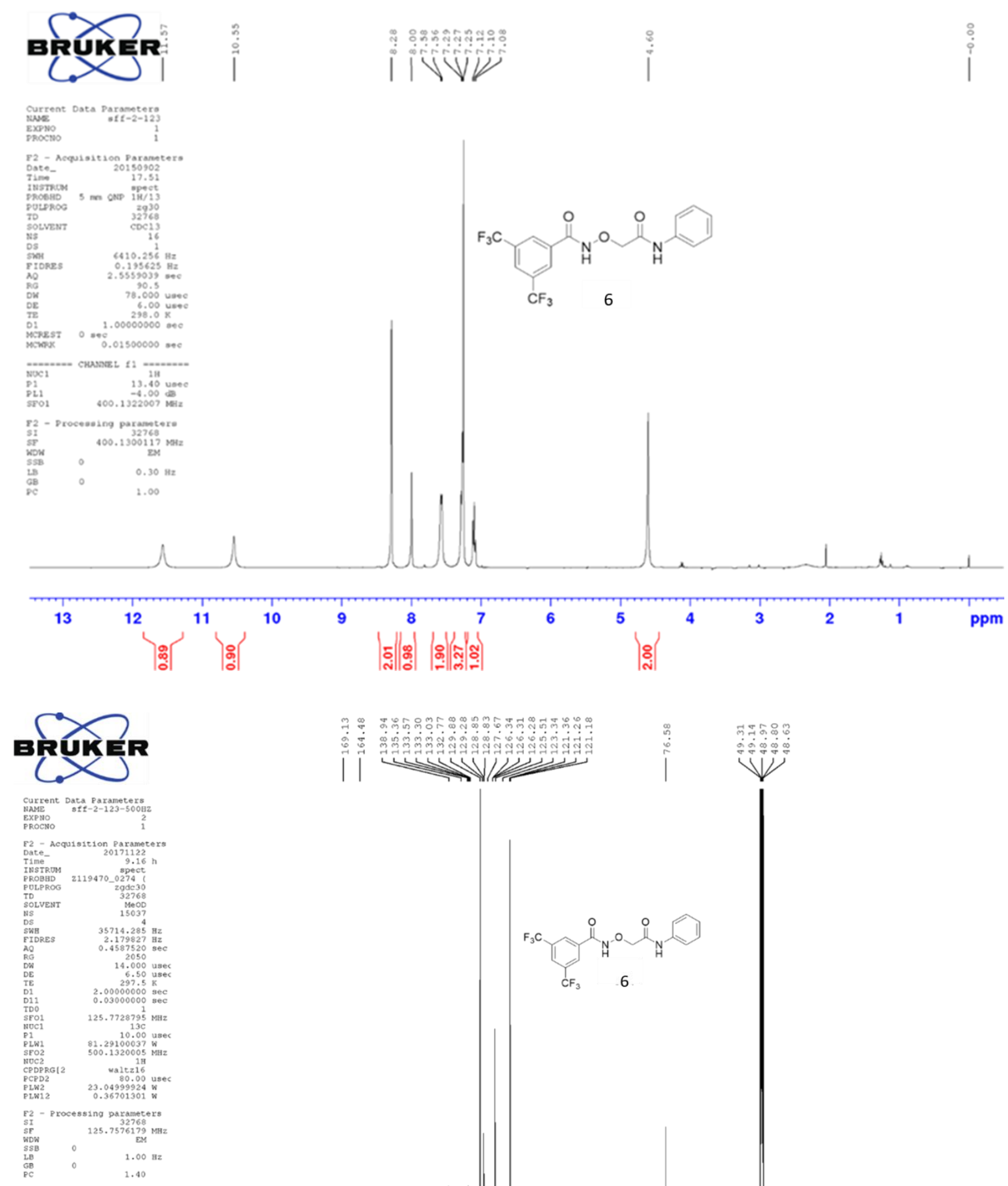


\section{BRUKER}

Current Data parametero
WIf
WIf $-2-123$

NAME
EXPNO
PROCNO

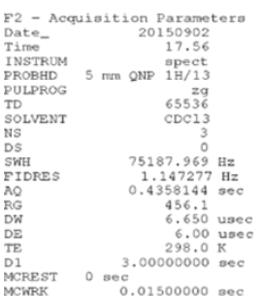

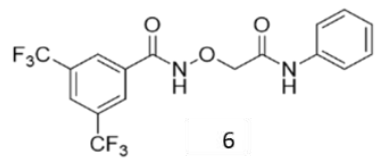

NuOC1
PN1

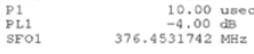

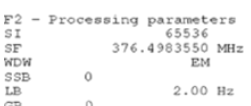

$\begin{array}{lll}\substack{G \mathrm{CB} \\ \mathrm{PC}} & 0 & 2.00 \\ \mathrm{PC} & 1.00\end{array}$

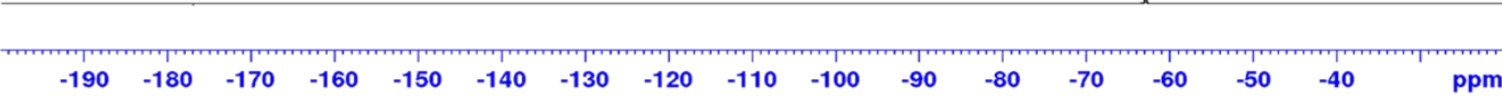

